الكتابات العربية في كنائس وأديرة طليطلة

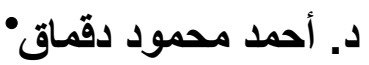

د. زينب شوقي سيا محمد دمثن

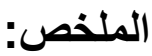

يتناول هذا البحث دراسة جديدة عن أثر الفن الإسلامي على الفن المسيحي الأندلسي

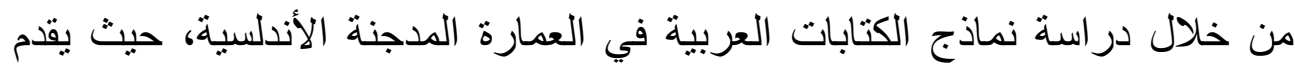

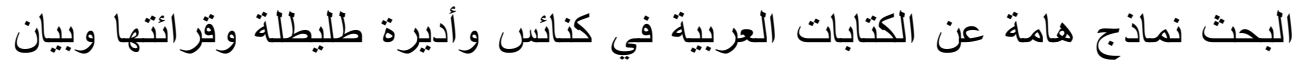

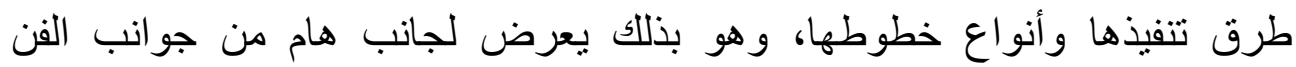

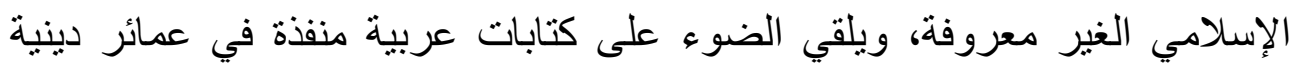

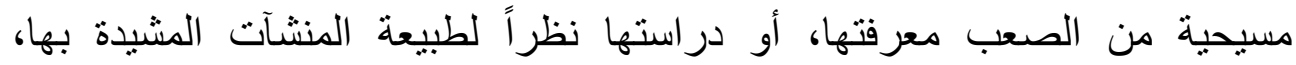

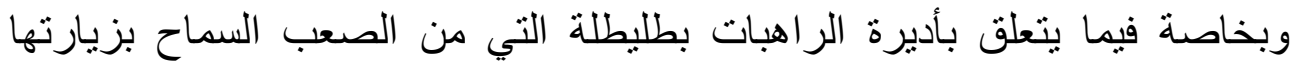

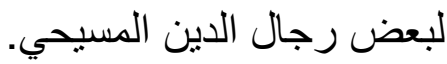

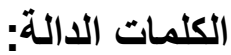

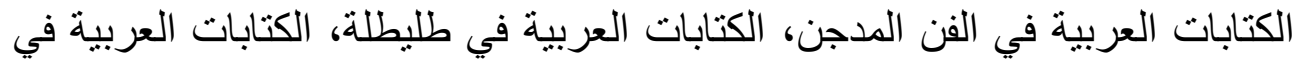
كنائس و أديرة طليطلة، أثر الفن الإسلامي على الفي الفن المسيحي الأندلسي.

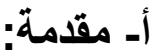

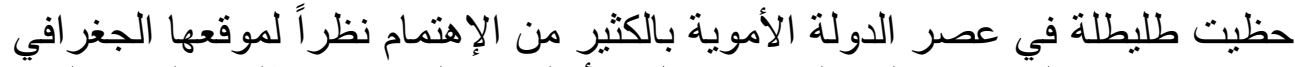

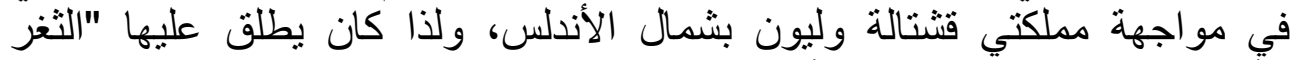

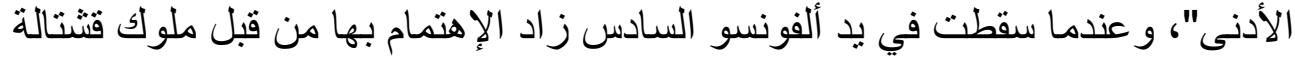

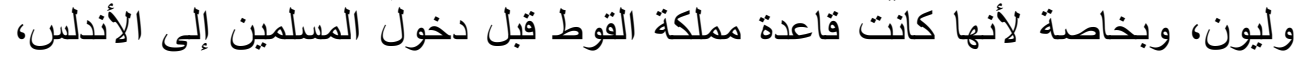

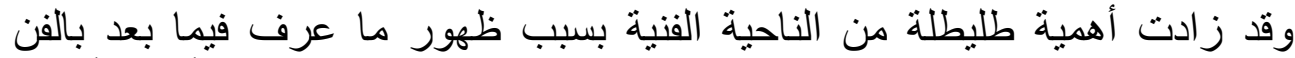

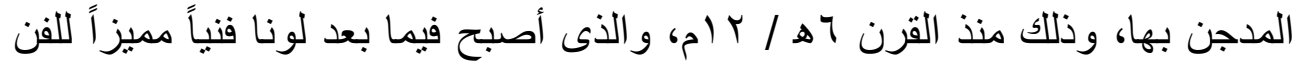

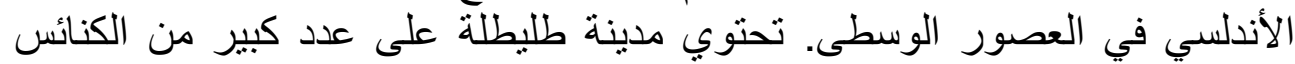

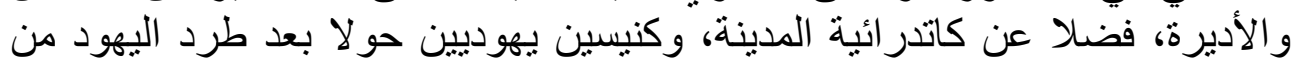

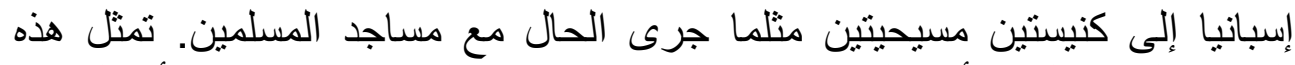

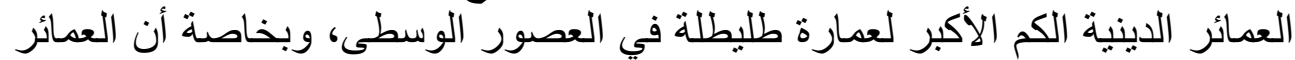

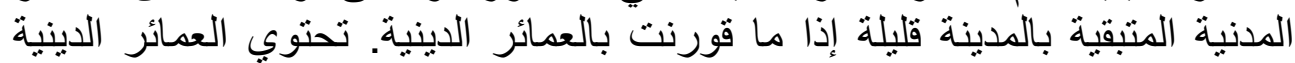

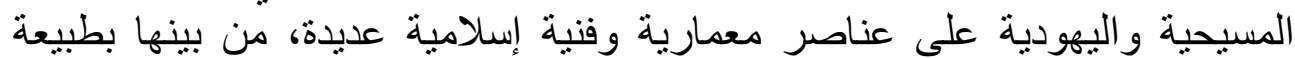
الحال الكتابات العربية، و هذا ما سوف يتم تناوله في هذا البحث.

• • أستاذ مساعد بقسم الآثار الاسلامية كلية الآثار- جامعة القاهرة aznydokmak@hotmail.com

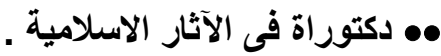




\section{1}

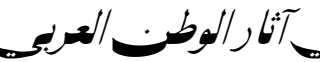

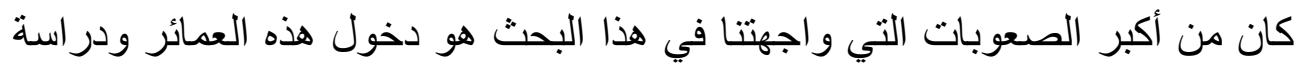

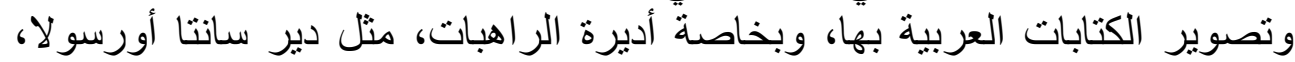

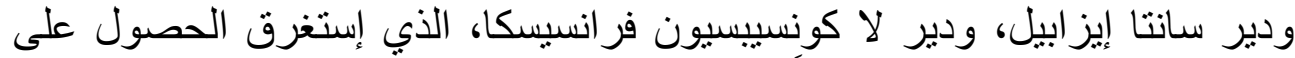

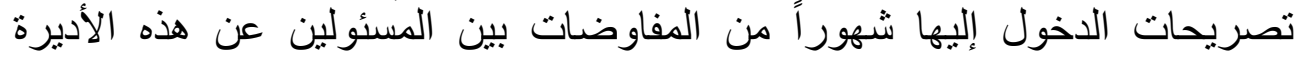

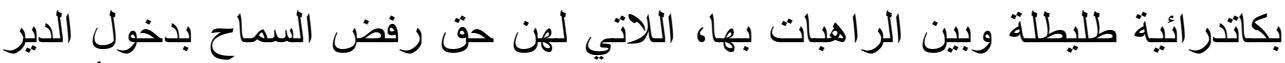

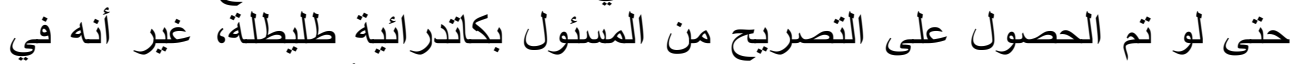

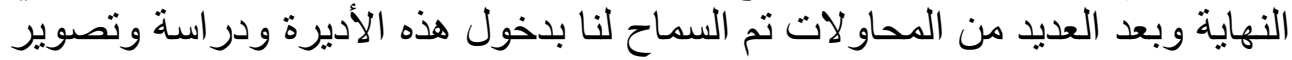

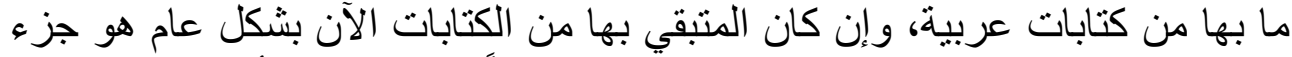

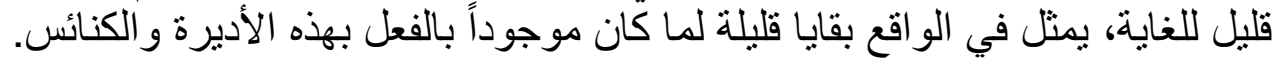

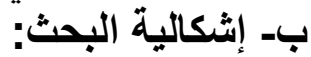

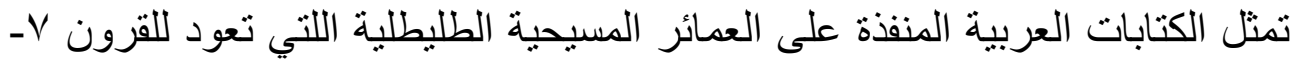

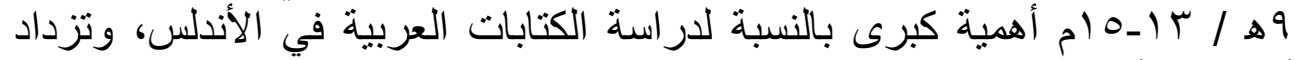

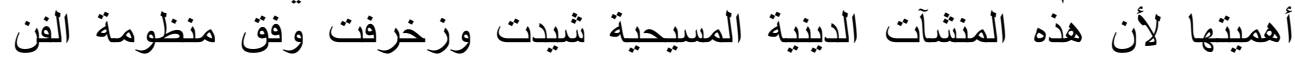

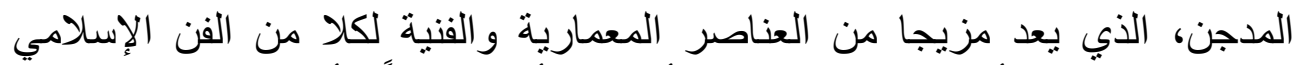

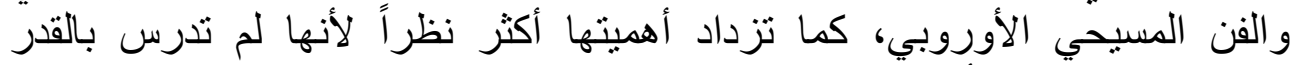

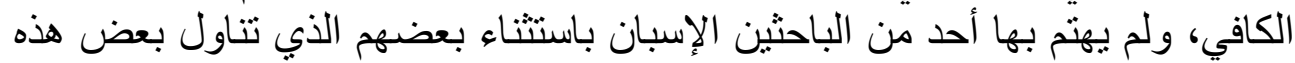

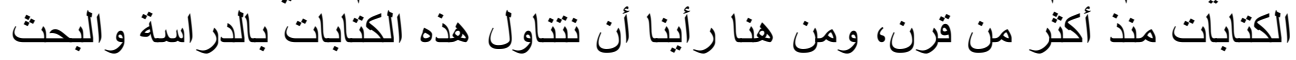

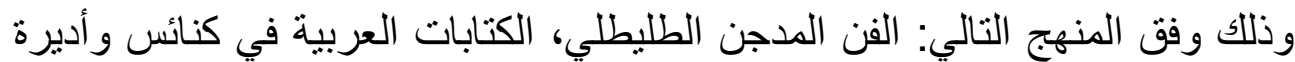

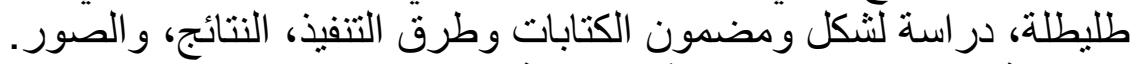
ا - بداية ظهور الفن المدجن في طليطلة:

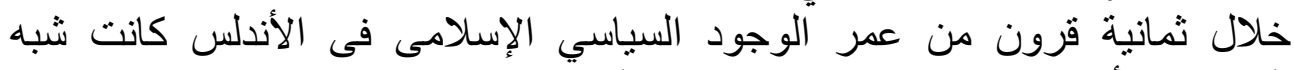

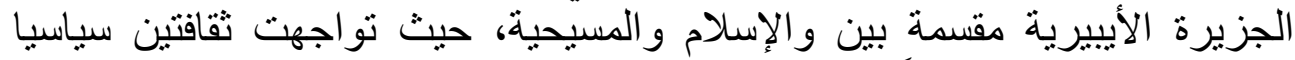

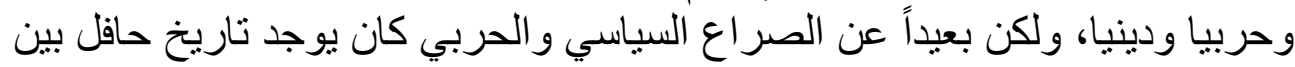

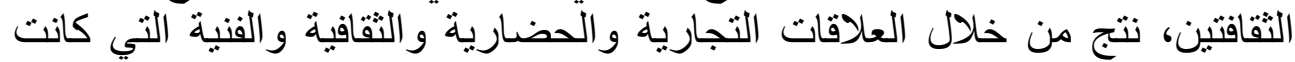

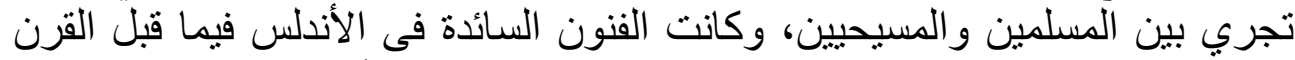

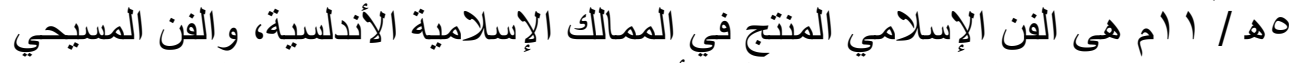

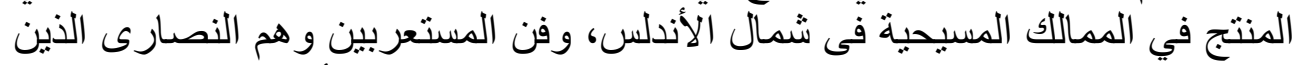

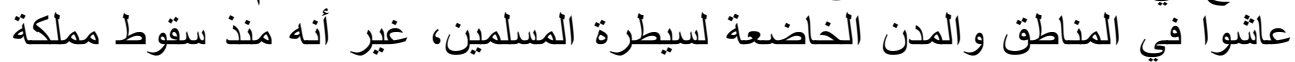

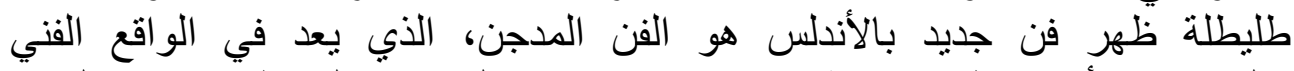
و الحضاري أكبر تظاهرة فنية عرفتها إسبانيا في العصور الوسطى وحتي الوقت الحاضر . - الحهر

ظهر الفن المدجن في البداية عقب سقوط مملكة طليطلة فى أيدى الفونسو السادس النس

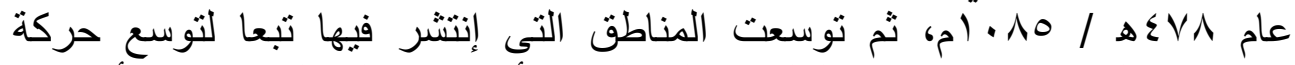

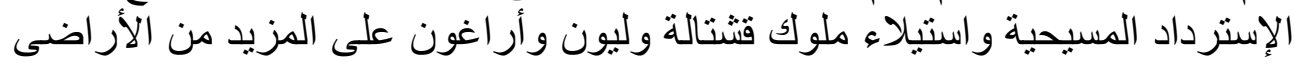

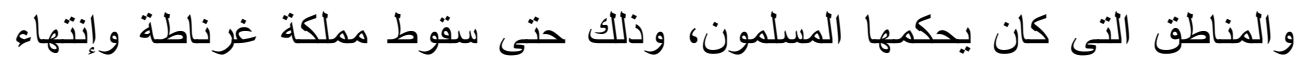




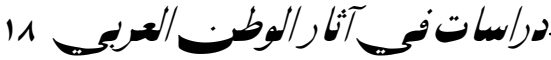

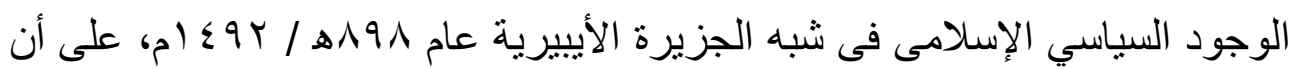

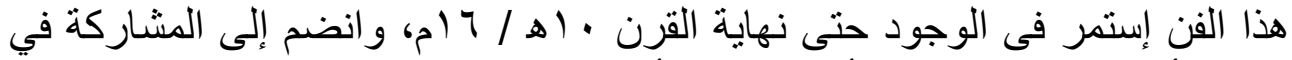

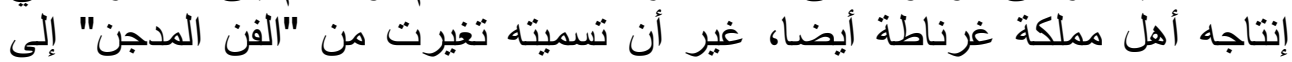

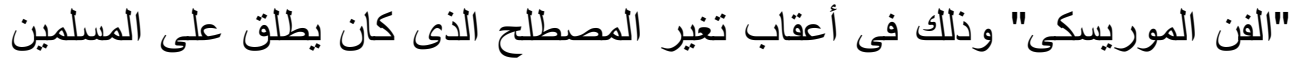

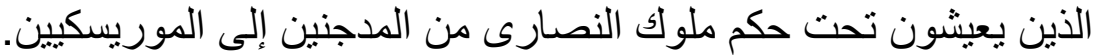

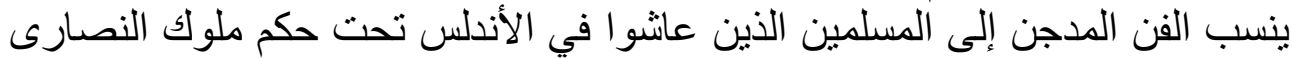

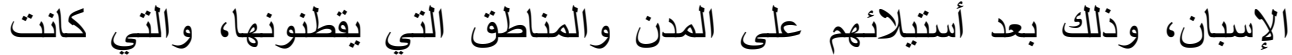

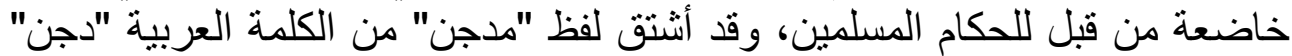

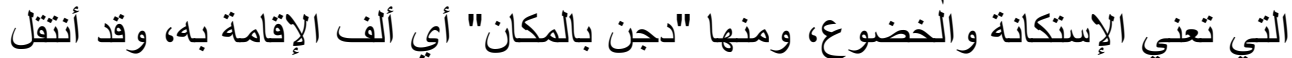

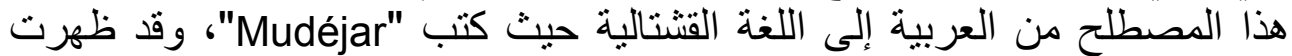

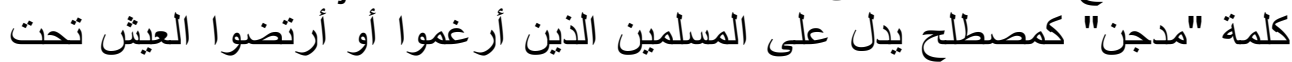

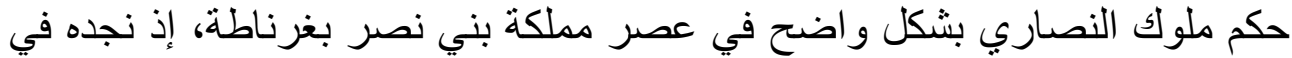

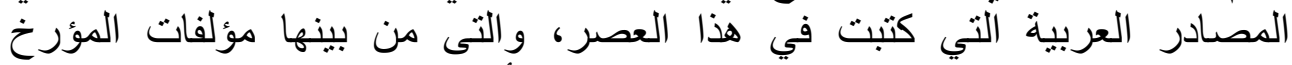

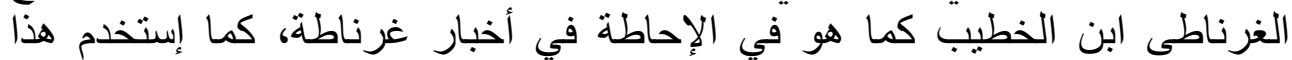

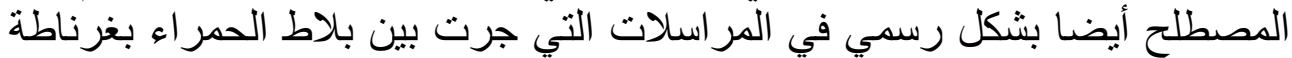
وبين ملوك أر اغون للإلالة على المسلمين المين القاطنين بمملكة أر اغون.

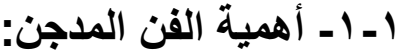

يعد الفن المدجن أحد الأضلاع الأندان الأساسية التى تطور من خلالها الفن الإسلامي في

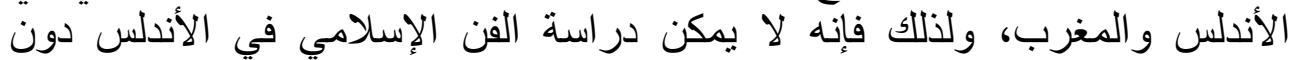

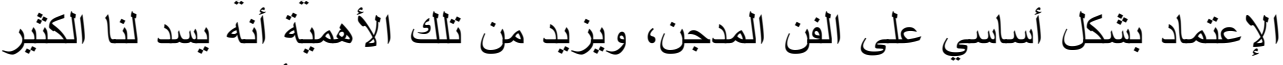

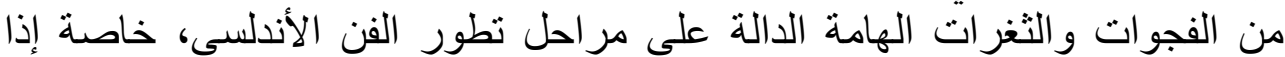

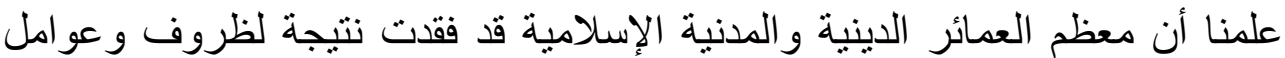

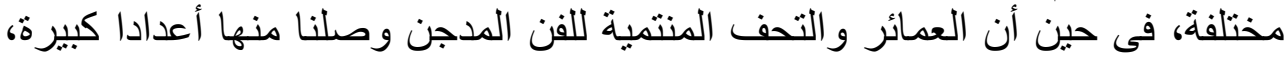

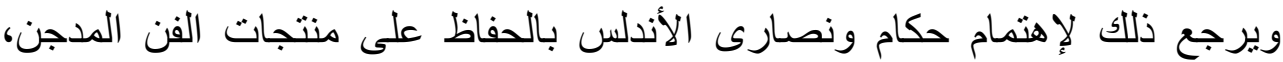
وذللك باعتباره فن منتج لهم، ولهذا فهو يتعلق بهم أكثر مما يتعلق بالمسلمين الذين

ساهمو ا في تشييده و إنتاجه.

يعتبر الفن المدجن ظاهرة فنية متفردة في العصور فئن الوسطى، بل فيعد لغة فنية جديدة

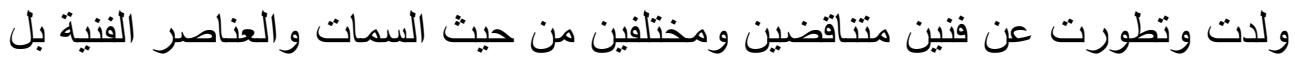

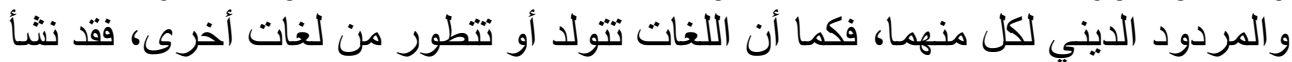

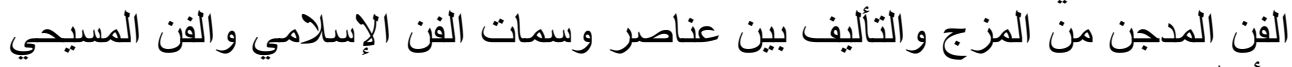
الأندلسي.

ظهر الفن المدجن فى الأندلس عندما إثترك كلا من الفنانيين المسيحيين و المسلمبين



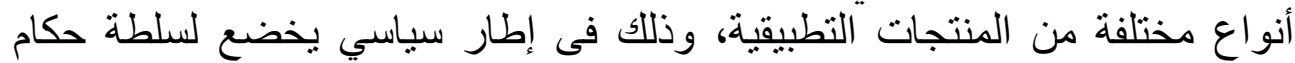
الممالك المسيسحية وبخاصة حكام قتنالة وليون وار اغون، ولذلك فقد جاء هذاء هذا الفن 


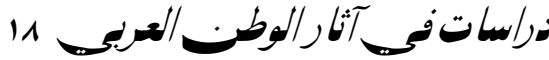

متفردا ومختلفا عن الفن الإسلامي والفن المسيحي الأوروبي، الذي إثتق سماته

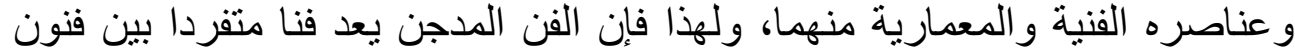

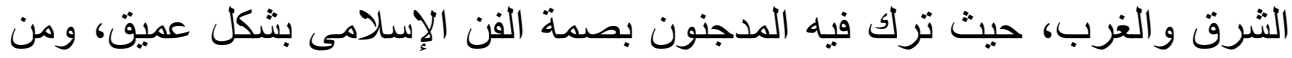

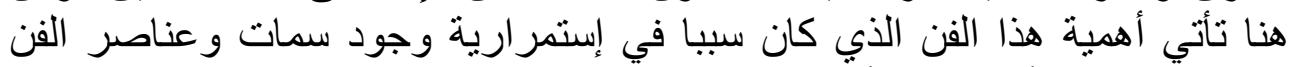

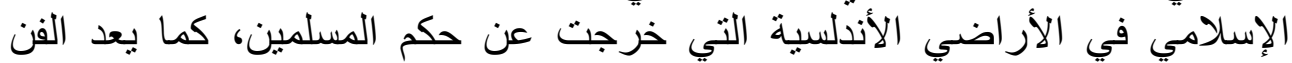

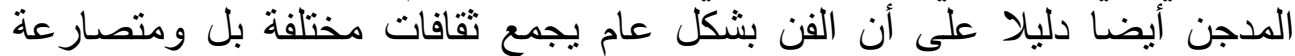

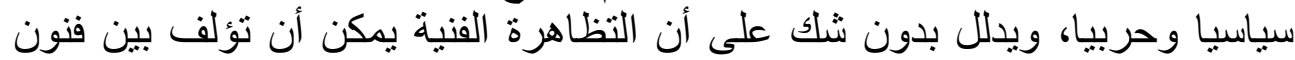

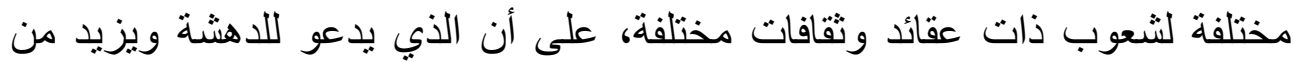

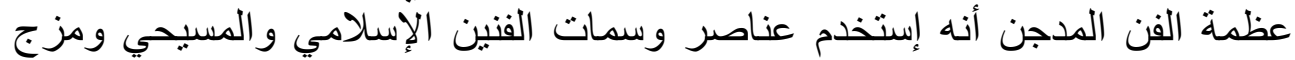

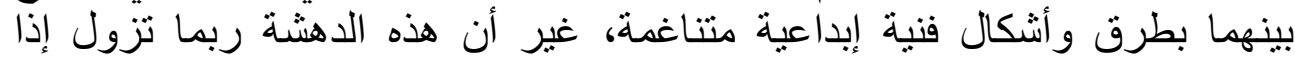

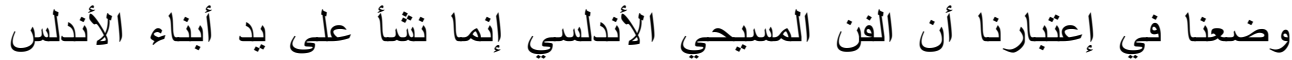

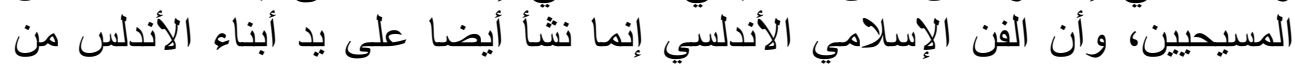

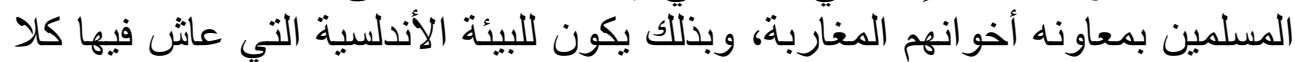

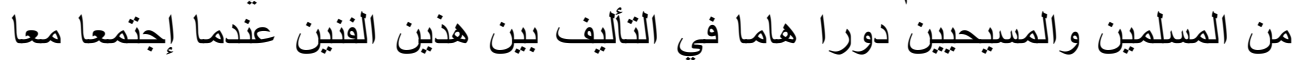
فيما عرف بالفن المدجن.

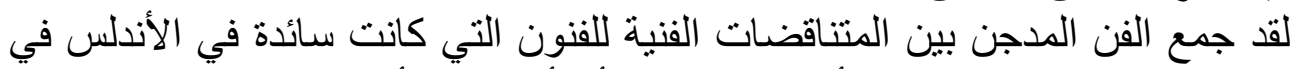

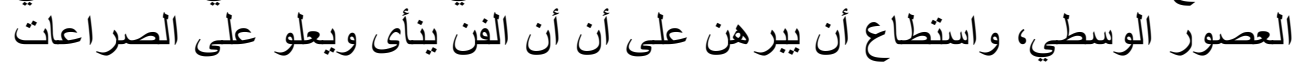

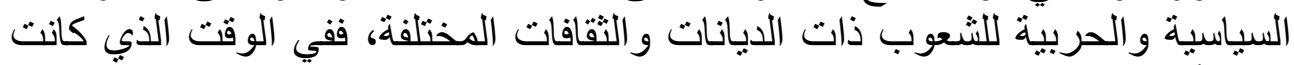

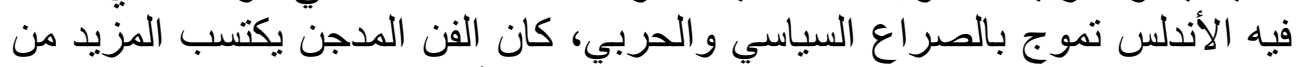

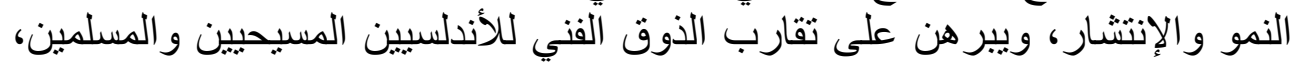

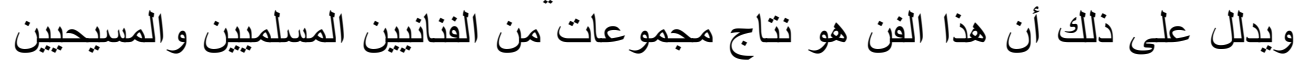

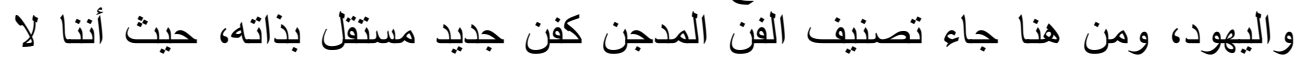

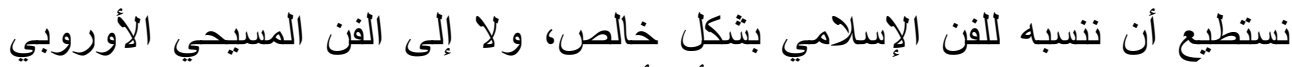

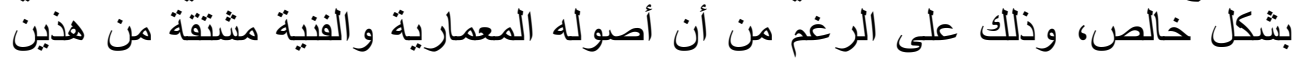

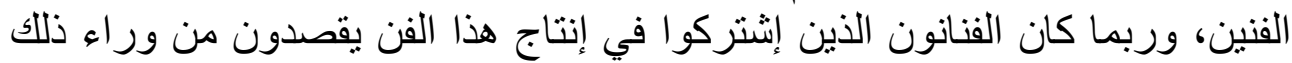

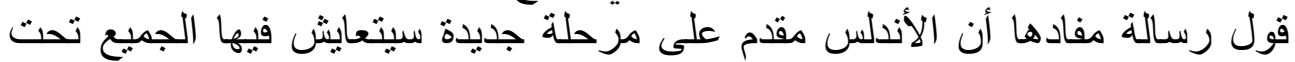

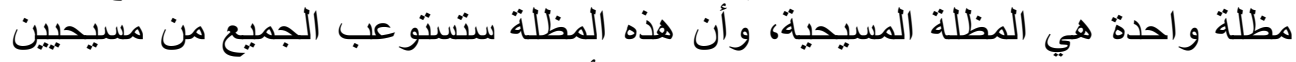

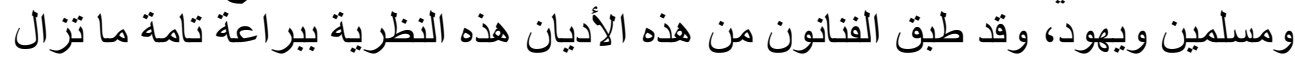

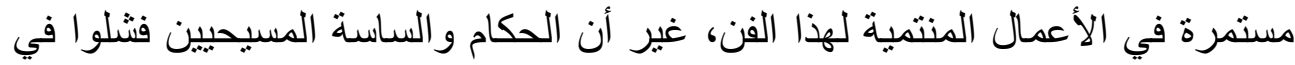

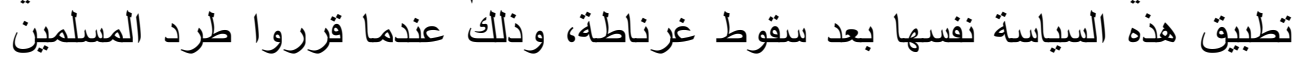

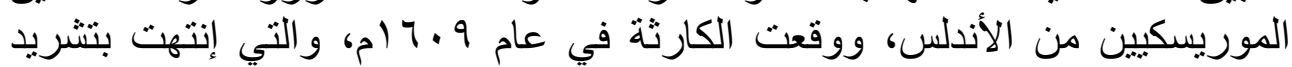

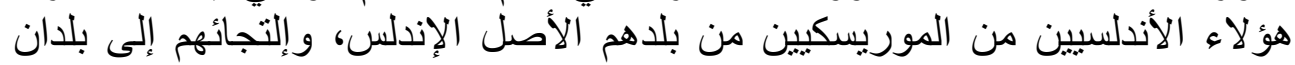
المغرب الإسلامي ومصر وبلاد الثام وغر ها من بلاد الدولة الإنة العثمانية. 


\section{ا - ب- - الفن المدجن الطليطلي:}

كانت طليطلة منذ الفتح الإسلامي للأندلس وحتى الفئ نهايات عصر الدولة الأموية تابعة

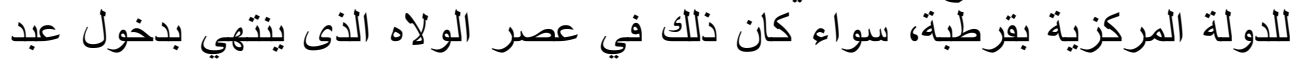

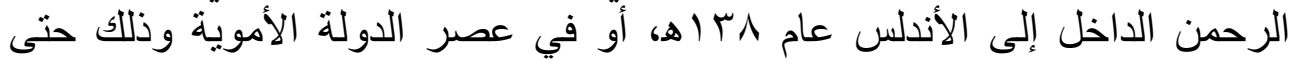

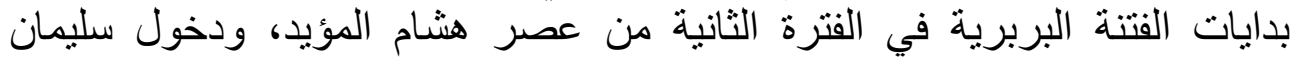

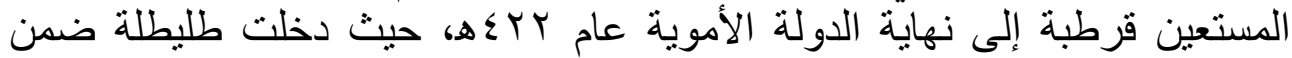

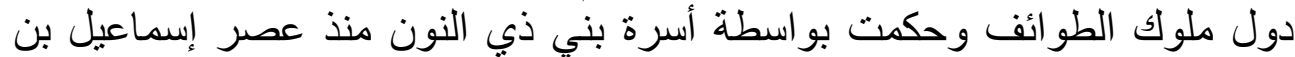

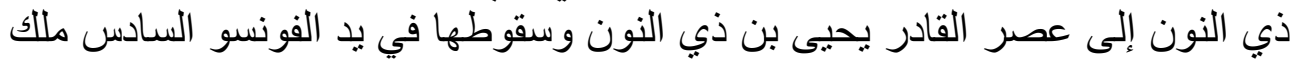

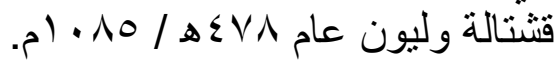

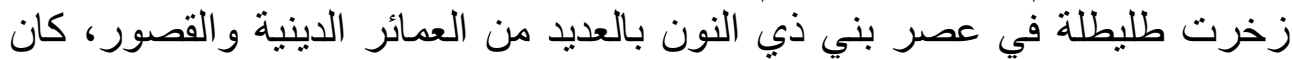

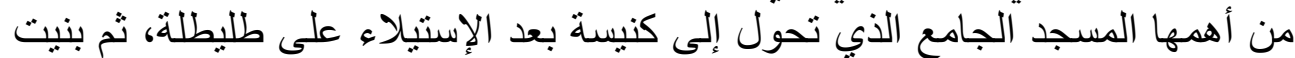

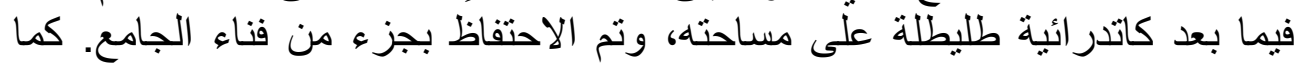
بنيت بعض كنائس طليطلة على مساجد المسلمين، بعد أن تم تعلى تعديلها معماريا بيناء

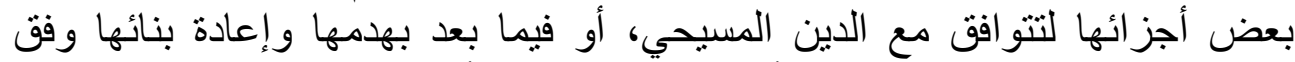

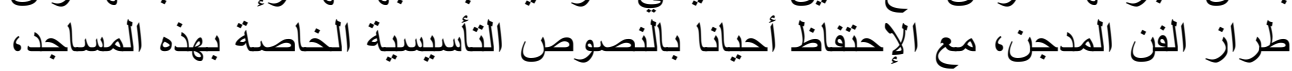

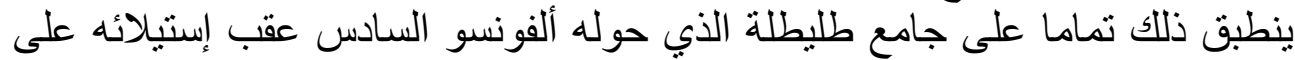

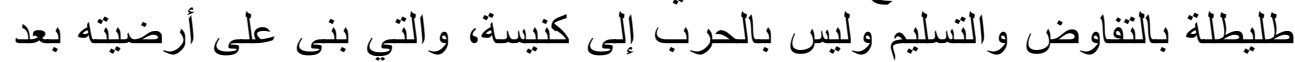

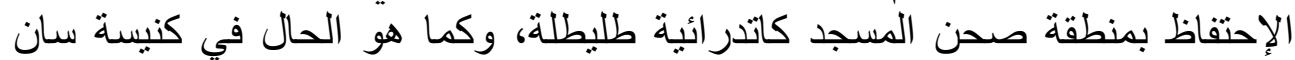



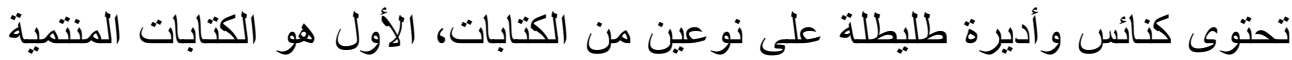

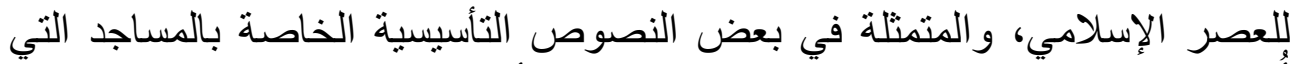

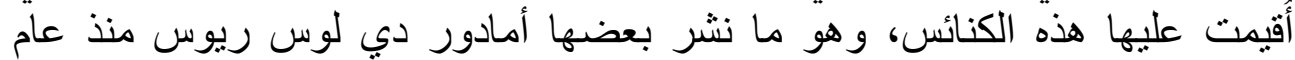

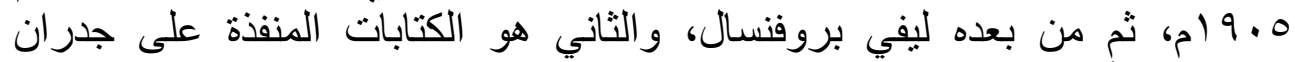

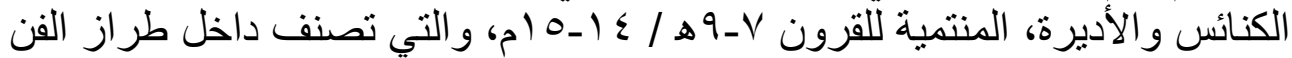

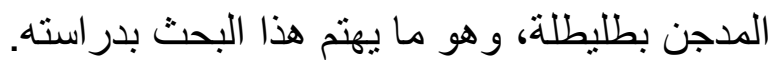

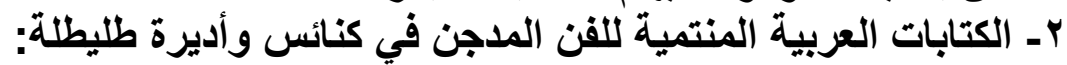

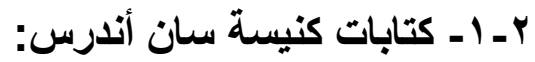

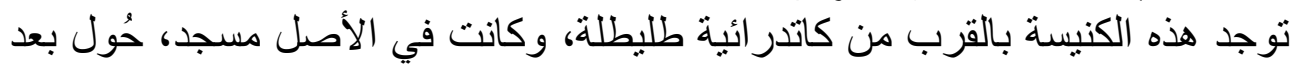

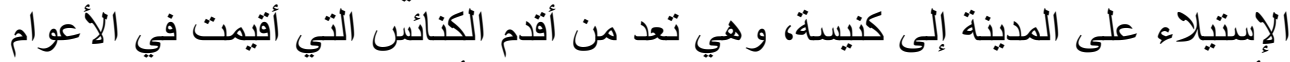

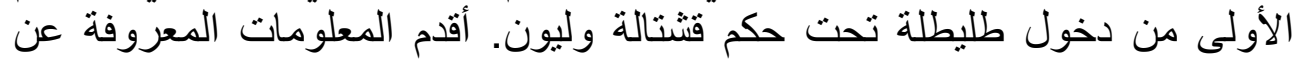

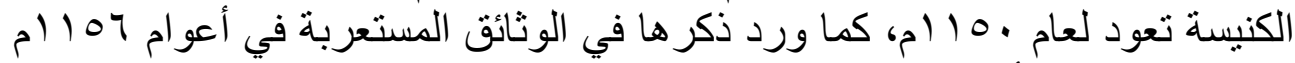

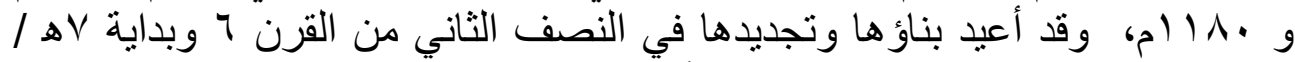

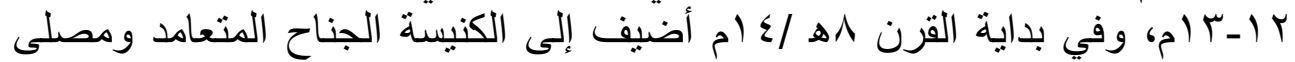




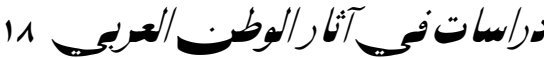

لاإبيفانييا'، الكتابات العربية المتبقية بالكنيسة تعود للتجديدات التي جرت في النصف

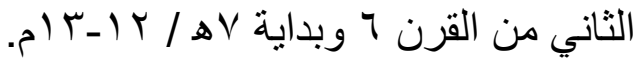

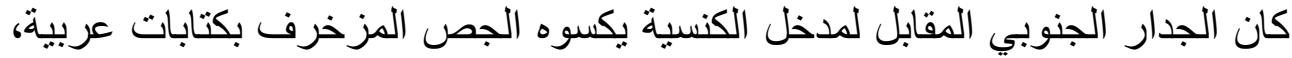

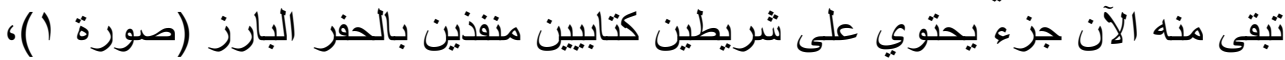

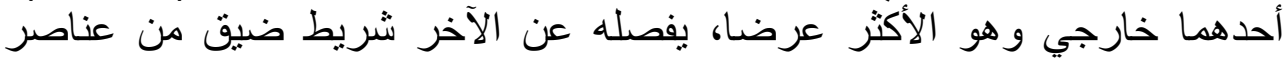

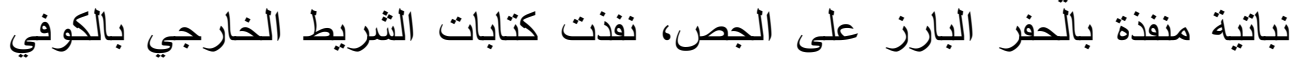

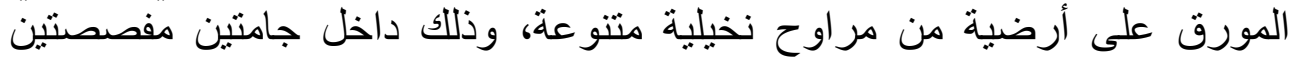

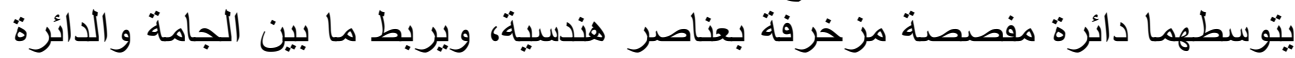

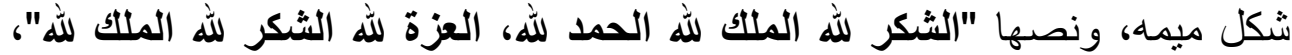

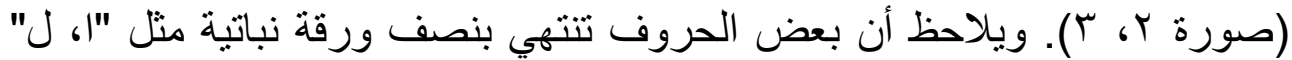

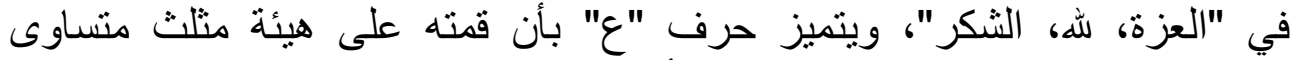

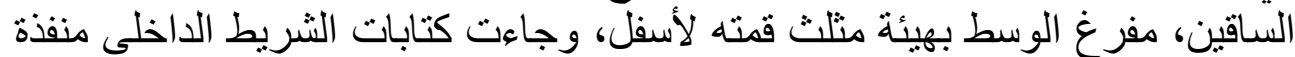

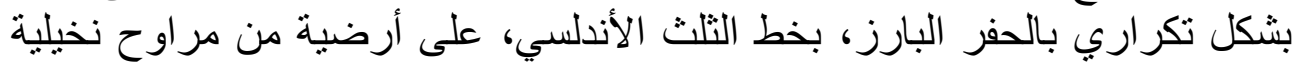

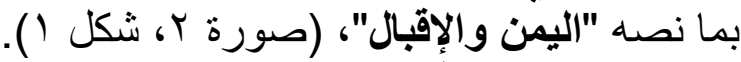

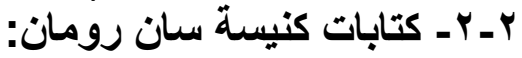

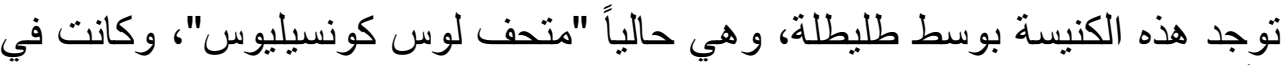

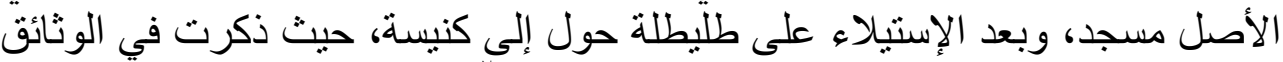

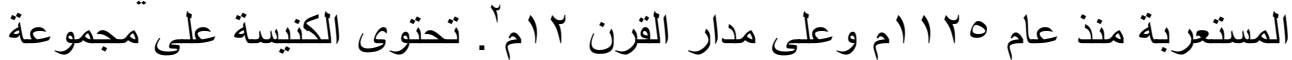

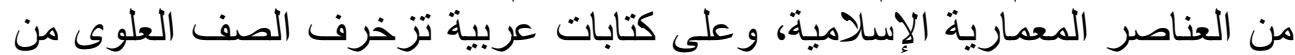

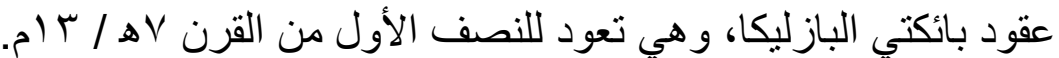

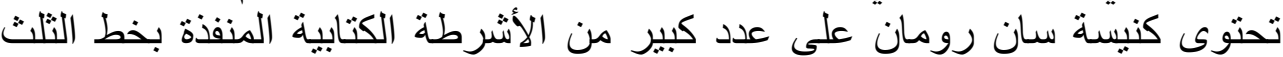

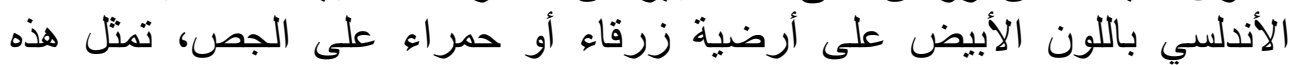

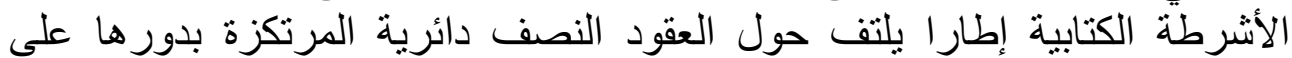

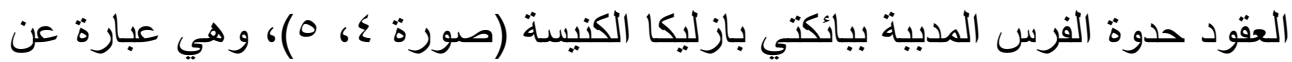

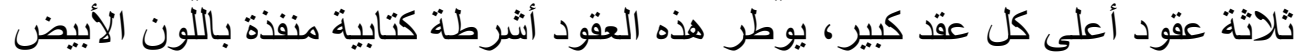

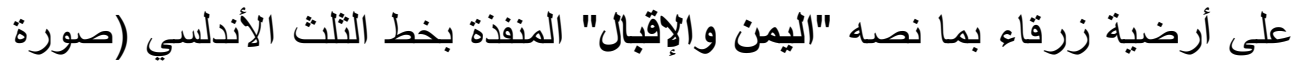
7)، كما تؤطر النو افذ الموجودة باء نالجانب الغربي من الكنيسة شريط كتابي منفذ باللون

1 RAMON PARRO, S., Compendio del Toledo en la mano, Toledo, 1858, p. 158; AMADOR DE LOS RIOS, J., Toledo pintoresca o descripción de sus más celebres monumentos, Barcelona, 1976, p. 160; PAVÓN MALDONADO, B., Arte toledano: Islámico y mudéjar, $2^{\mathrm{a}}$ edición, Madrid, 1988, p. 63; FRANCO MATA, M. A., "Toledo gótico", en: Arquitectura de Toledo. Del Renacimiento al Racionalismo, Toledo, 1992, pp. 533-534; DOKMAK, A., Estudio de los elementos islámicos en la arquitectura mudéjar en España a través de las bóvedas de mocárabes y de ejemplos de la epigrafía árabe, Tesis Doctoral, Universidad Complutense de Madrid, 2001, pp. 138-144.

2 PEREZ HIGUERA, T., "Iglesia de San Román", en: Arquitectura de Toledo. Del Renacimiento al Racionalismo, Toledo, 1992, pp. 233-237. 


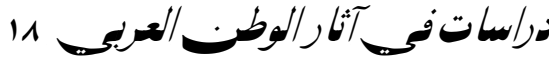

الأبيض على أرضية زرقاء (صورة V)، وكذللك كل نافذة من النافذتين الجانبيتين ذاتا

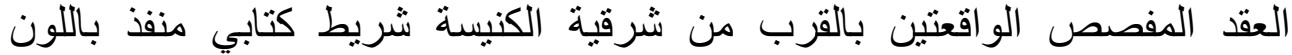

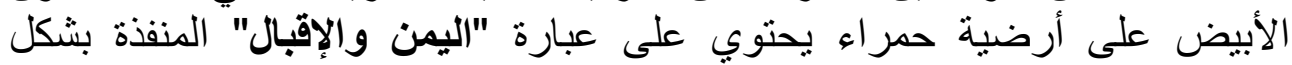
تكر اري بنفس نوع الخط الخط.

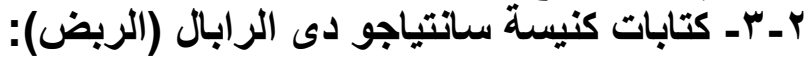

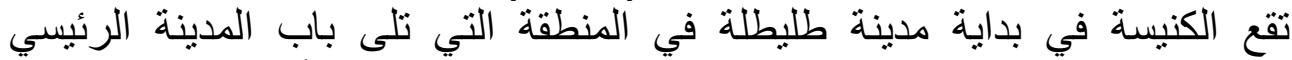

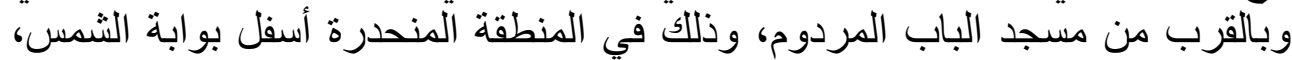

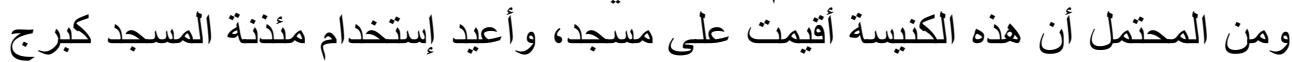

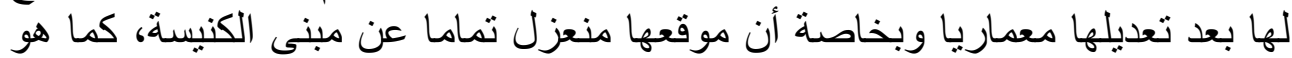

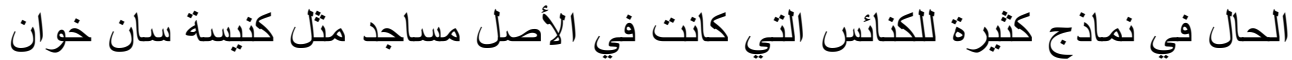

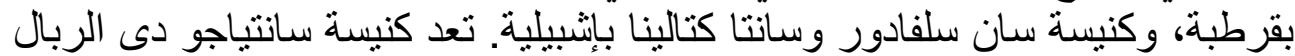

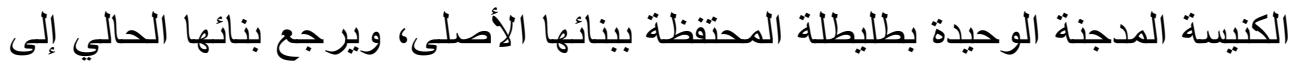

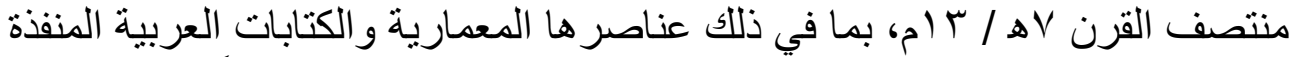

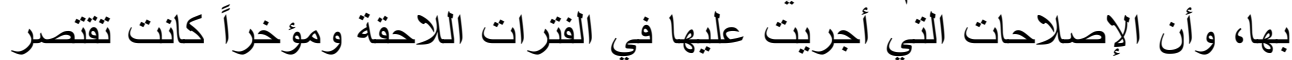
على صيانتها فقط" الإحات. يزخرف الإزار الممتد أسفل جانبي السقف الجملوني للجزء الأوسط من كنيسة

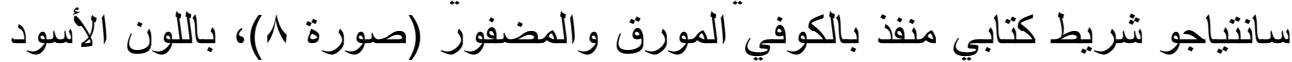

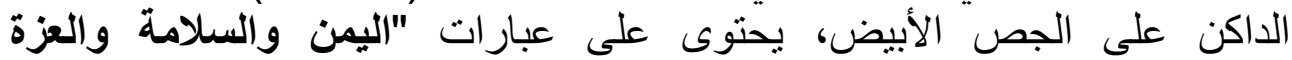

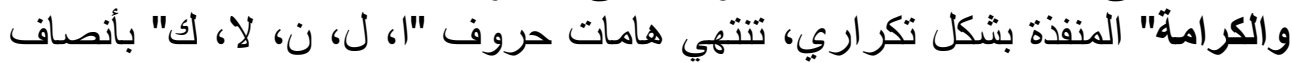

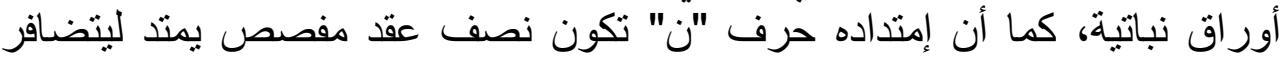

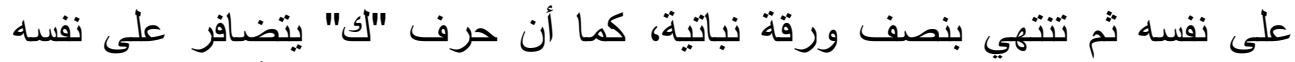

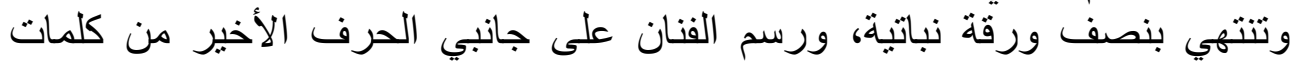

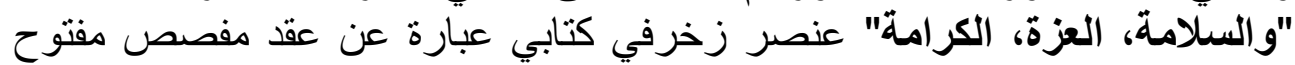

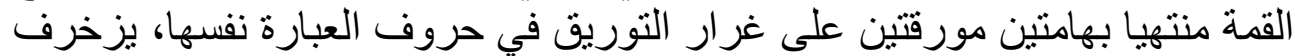

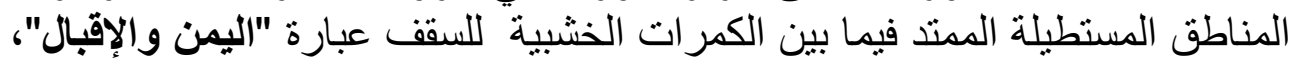

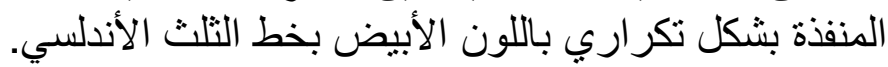

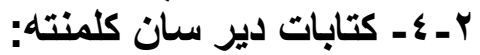

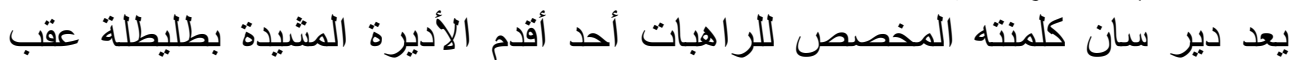

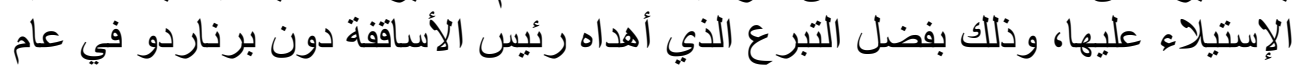

${ }^{3}$ AMADOR DE LOS RIOS Y VILLALTA, R., Monumentos arquitectónicos de España. Toledo, Madrid, 1905, pp. 231-232; PEREZ HIGUERA, T., "Iglesia de Santiago del Arrabal", en: Arquitectura de Toledo. Del Renacimiento al Racionalismo, Toledo, 1992, pp. 285-293. 
9 • ا ( م، و هو العام الذي توفي فيه الملك ألفونسو السادس، و العديد من الوثائق نثير

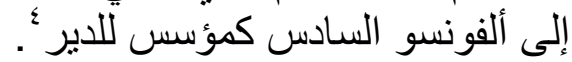
يمثل السقف الخاص بقاعة الطعام بدير سان كلمنته "San Clemente" أحد أقدم أمثلة

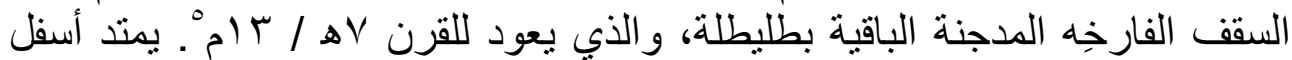

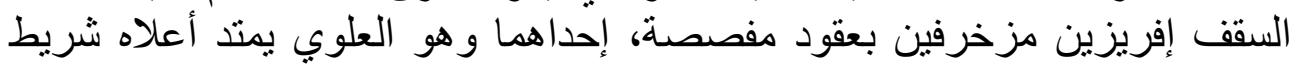

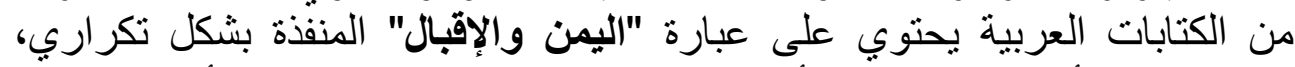

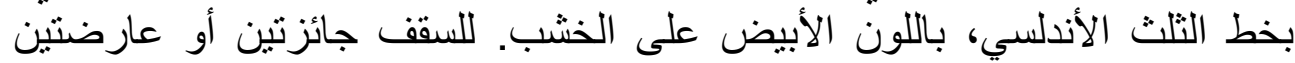

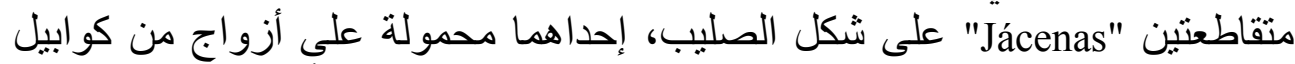

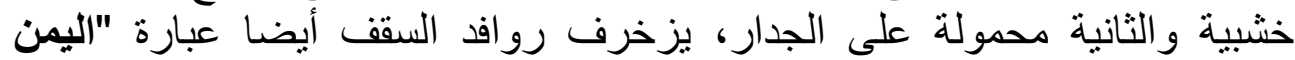

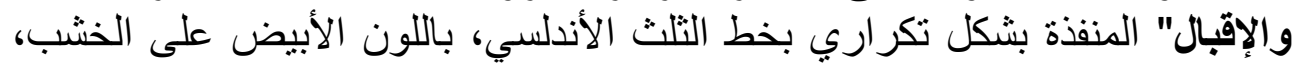

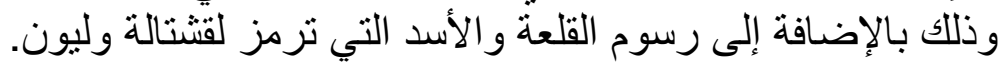

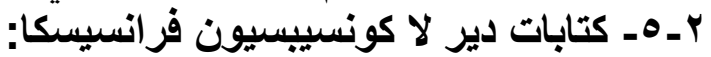

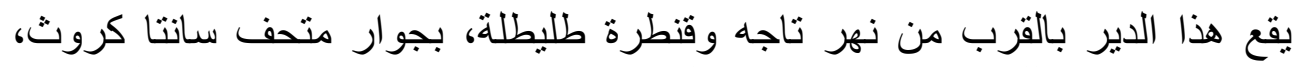

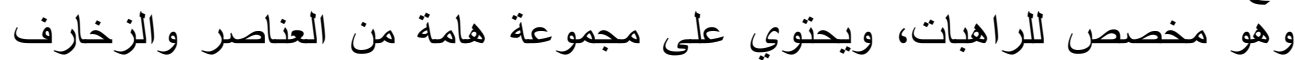

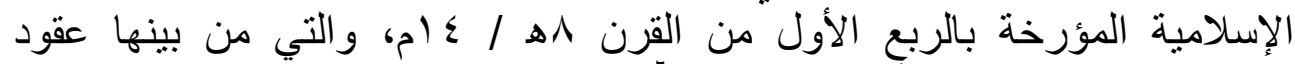

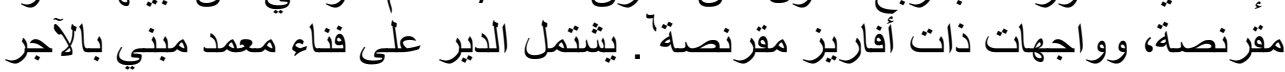

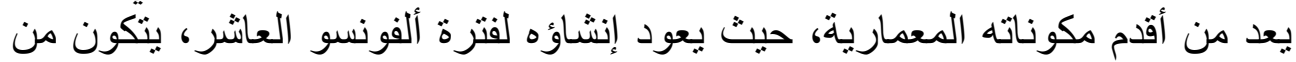

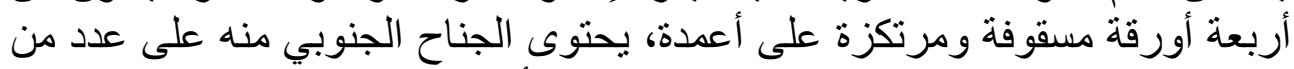

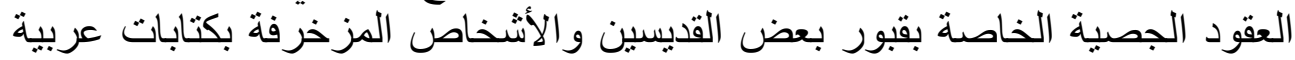
مثتو عة.

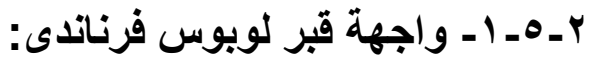

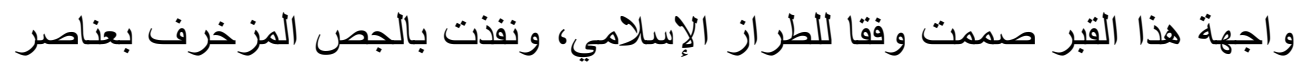

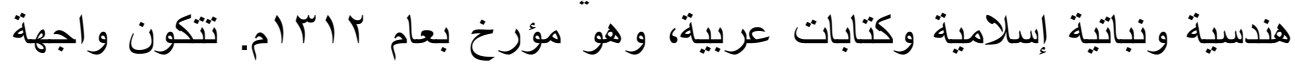

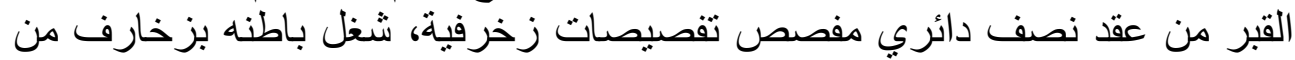

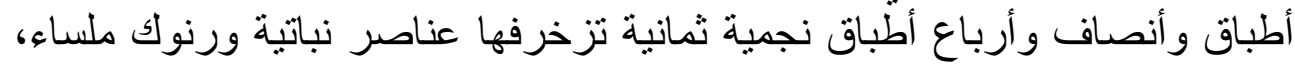

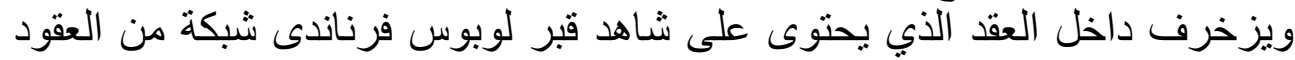

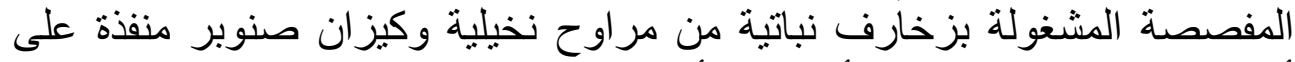
أرضية مصبوغة باللونين الأحمر والأزرق. يزخرف خرف كوشتي العقد زخارف نباتية

${ }^{4}$ MARTíneZ CAVIRO, B., Mudéjar toledano. Palacios y conventos, Madrid, 1980, p. 283.

5 MARTÍNEZ CAVIRO, B., Mudéjar toledano, 1980, p. 287-288, figs. 252, 523; MARTÍNEZ CAVIRO, B., "Carpintería mudéjar toledana", Cuadernos de la Alhambra, 12, Granada, 1976, p. 230, láms. I, II.

${ }^{6}$ AMADOR DE LOS RIOS Y VILLALTA, R., Monumentos arquitectónicos de España, pp. 368-374; MARTÍNEZ CAVIRO, B., Mudéjar Toledano, 1980, pp. 48, 52, figs. 15, 2528. 


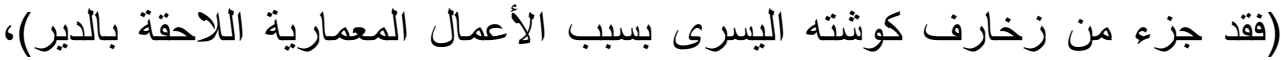

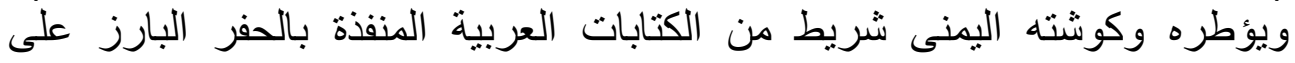

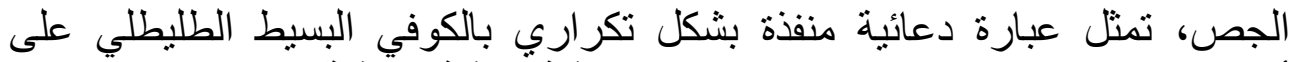

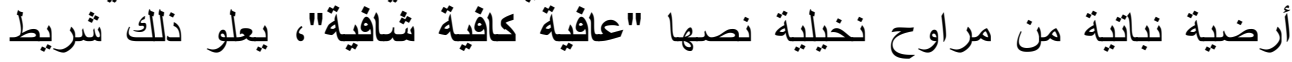

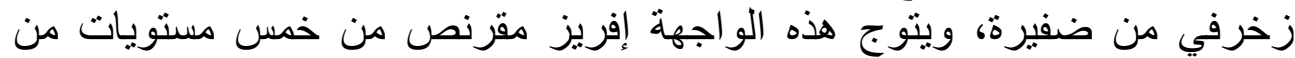

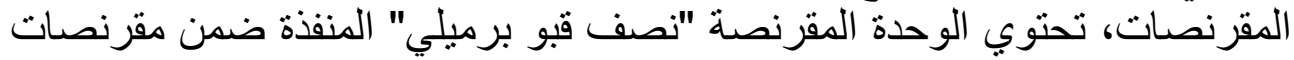

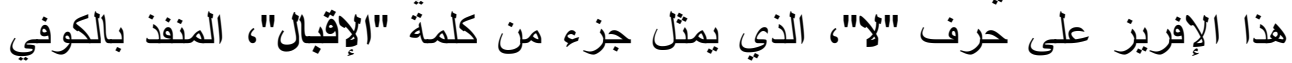

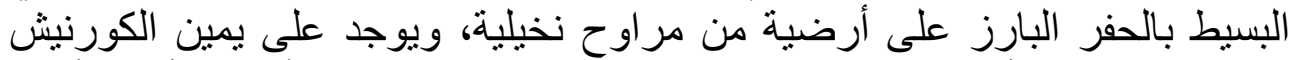

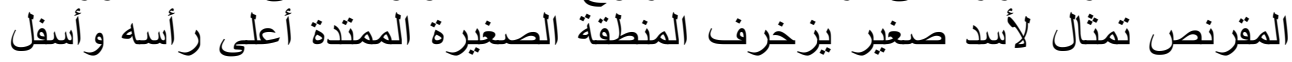

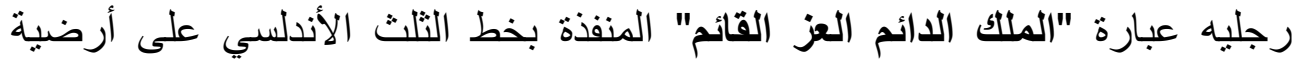

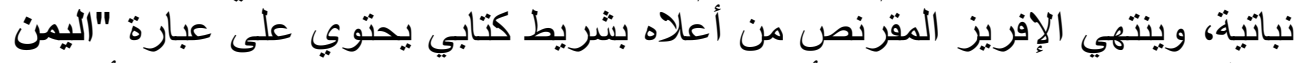
والإقبال"المنفذة بخط الثلث الأندلسي بشكل تكراري بالحفر البارز على على أرضية

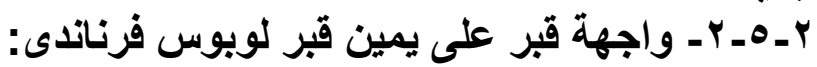

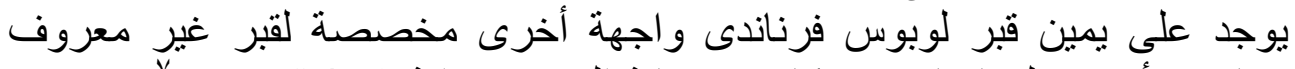

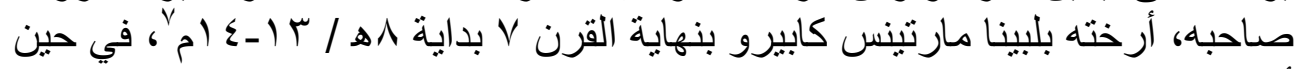

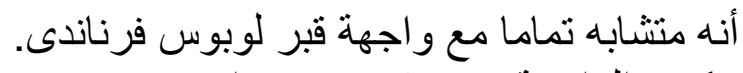

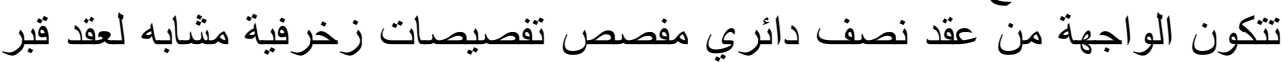

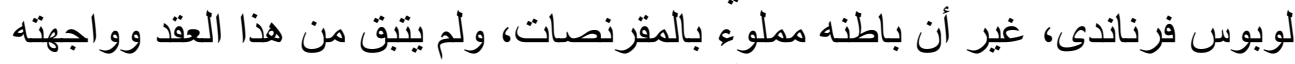

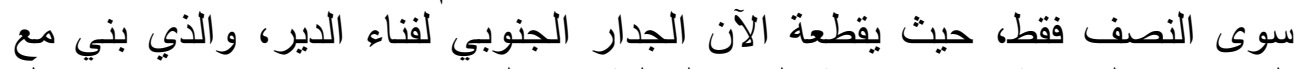

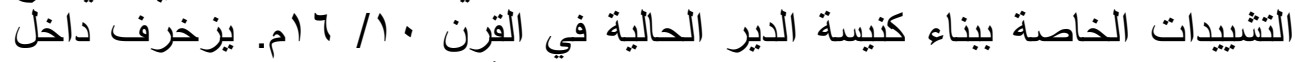

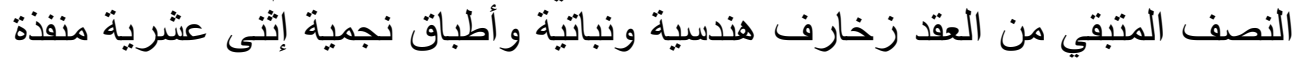

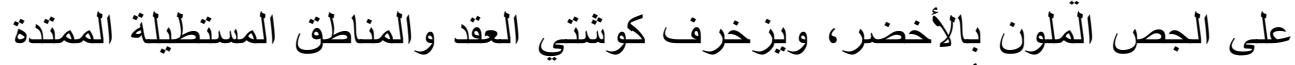

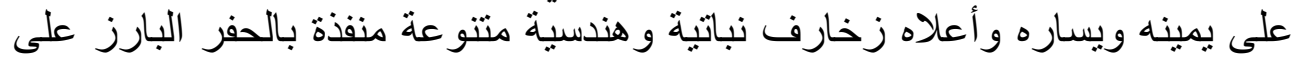

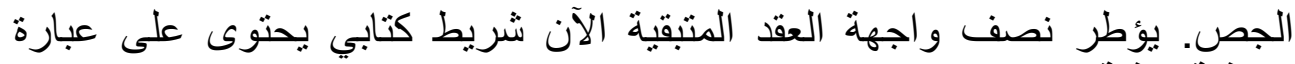

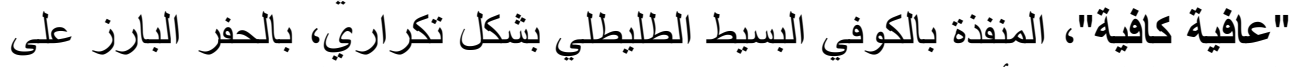

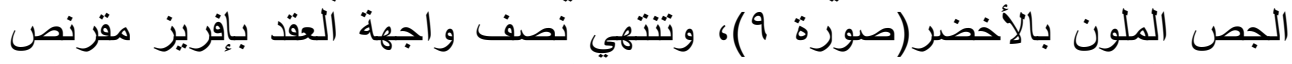

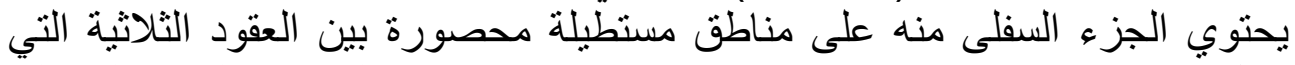

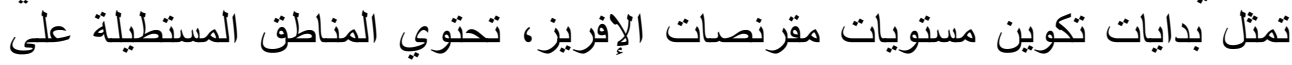

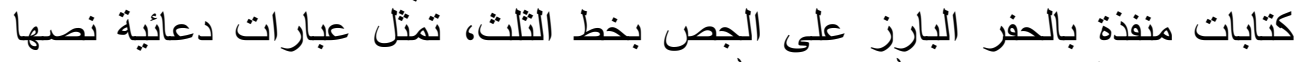

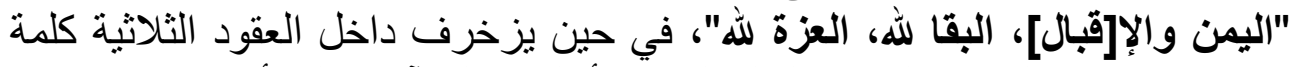
"يم[ن]" منفذة بالكوفي البسيط الطليطلي، بالأسلوب المر آني على أرضية نباتية من النية

${ }^{7}$ AMADOR DE LOS RIOS Y VILLALTA, R., Monumentos arquitectónicos de España, pp. 248-263; MARTÍNEZ CAVIRO, B., Mudéjar toledano, pp. 57, 59-60, figs. 31, 32. 


\section{1}

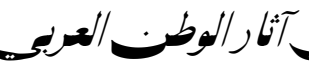

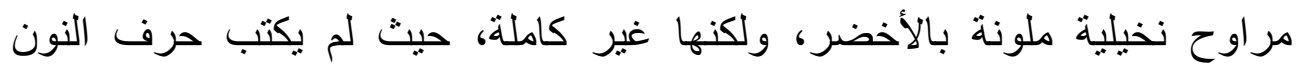

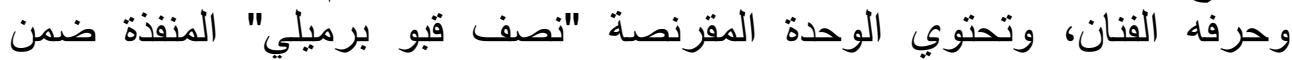

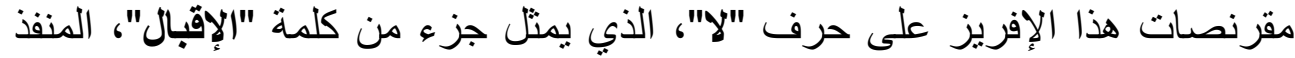

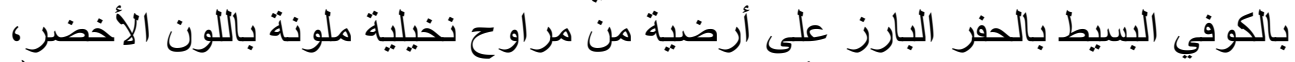

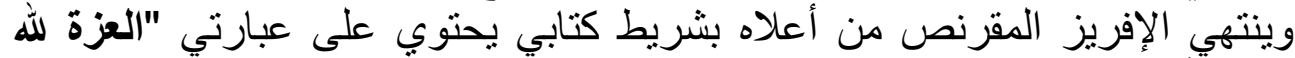

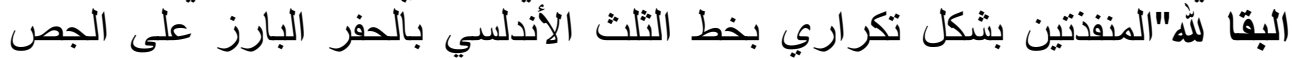

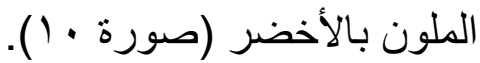

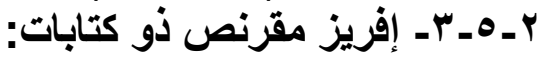

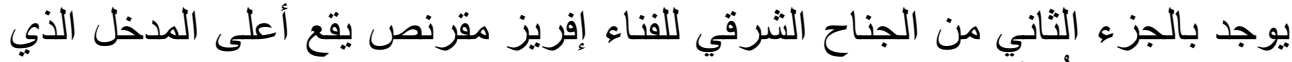

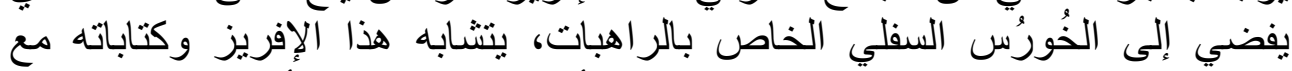

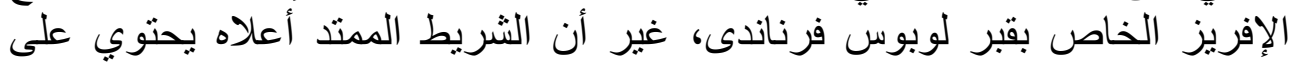

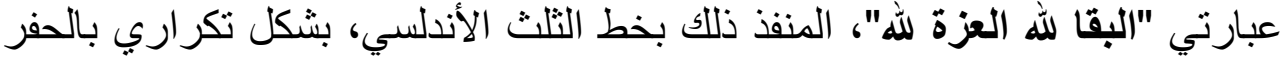

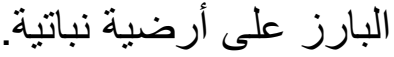

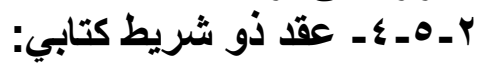

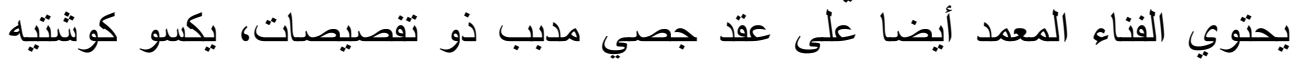

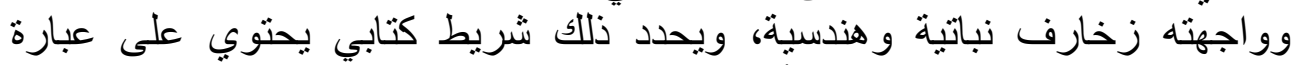

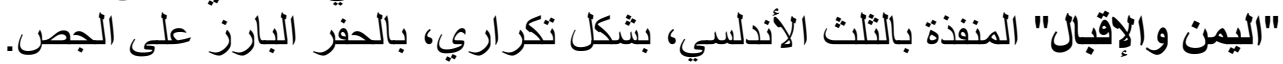

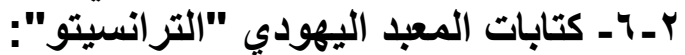

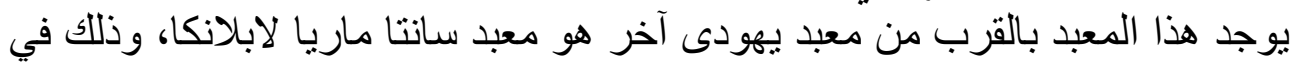

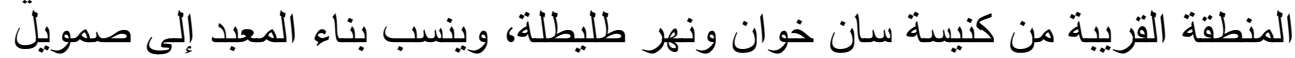

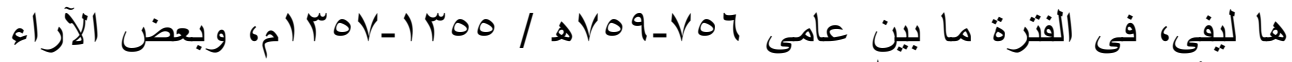

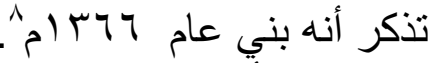
يزخرف الأجزاء العلوية من جدران القاعة الرئيسية المستطيلة إطار جصي عريض

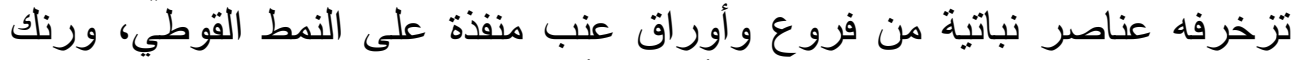

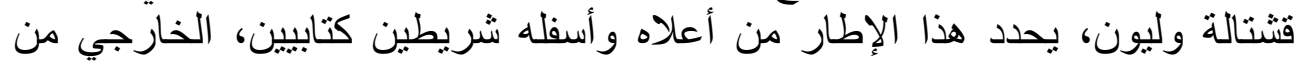

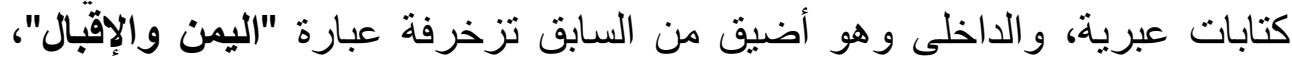

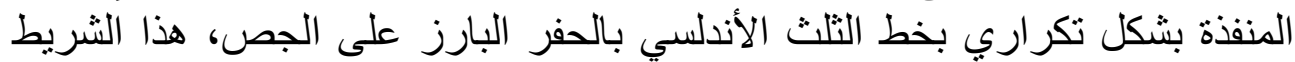

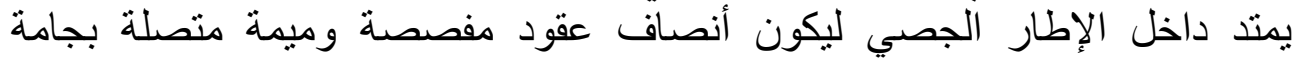

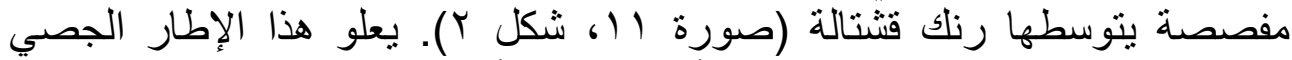

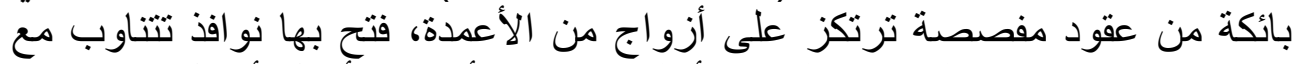

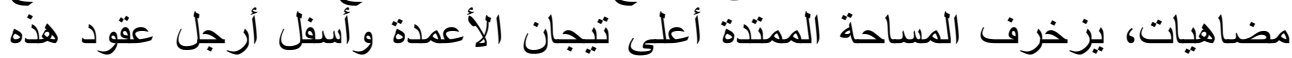
البائكة شريط كتابي ضيق يحتوي على عبارة "اليمن والأقبال" المنفذة بنفس الأسلوب الأب الئل

${ }^{8}$ CAMON AZNAR, J., Sinagogas de Toledo, Segovia y Córdoba, Madrid, 1973, pp. 4950; CONTRERAS, J. DE., Historia del arte hispánico, tomo 2, $1^{\text {a }}$ ed., Barcelona, 1934, pp. 452-453, fig. 469. 


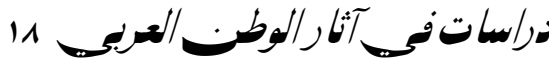

السابق، ويزخرف الأفريز الخشبي الممتد أسفل السقف الخشبي للصالة الرئيسية

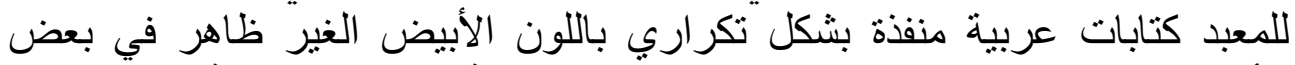

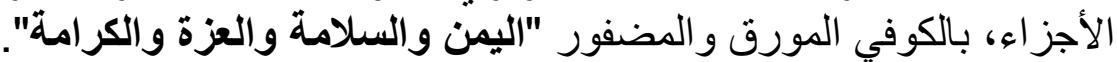

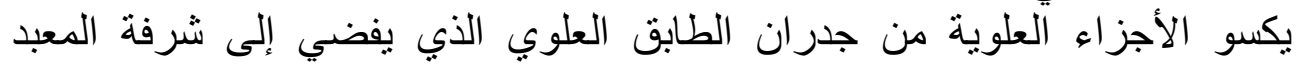

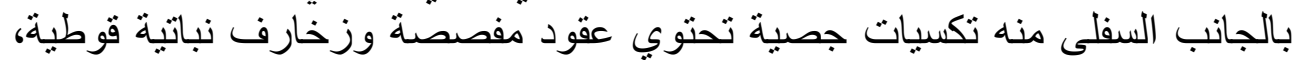

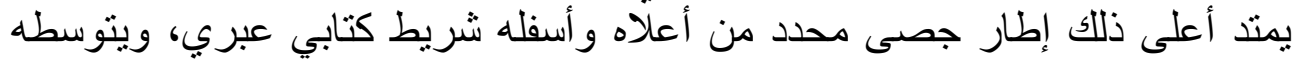

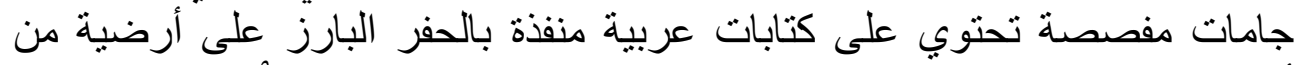

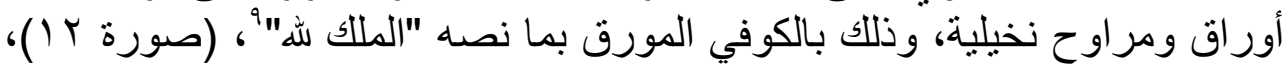



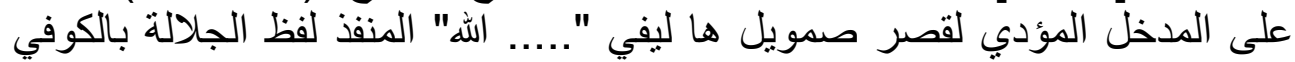

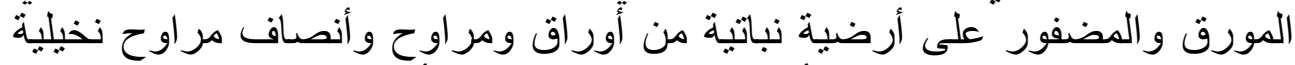

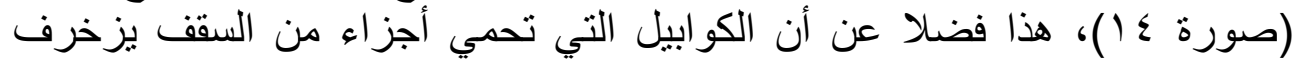

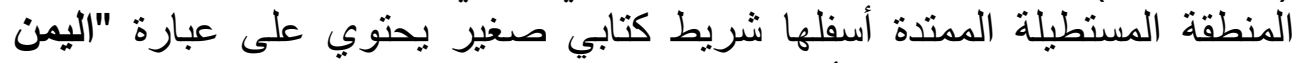

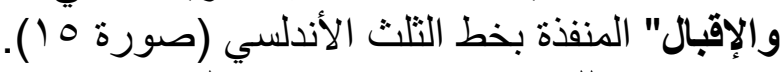

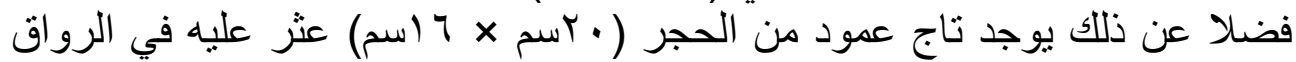

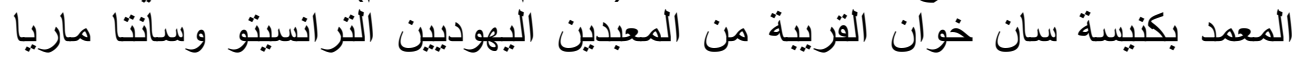

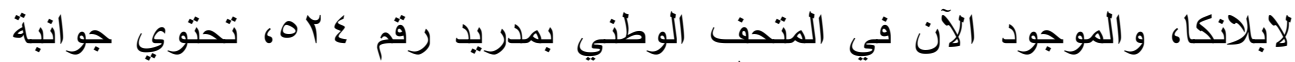

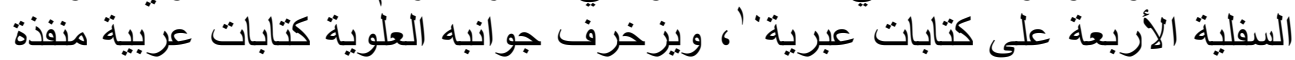

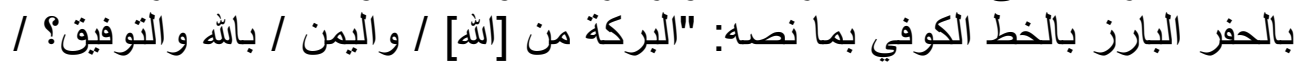

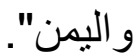

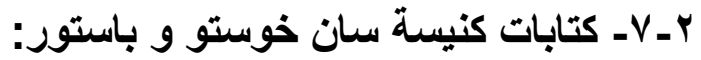

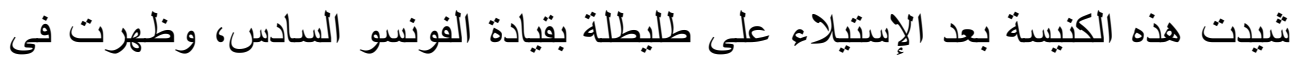

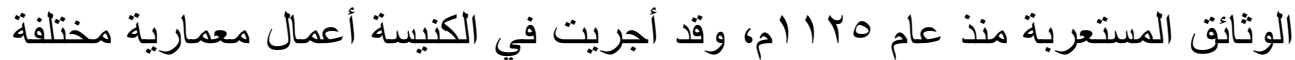

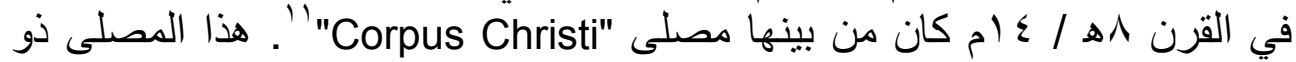

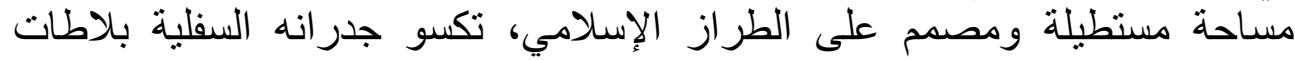

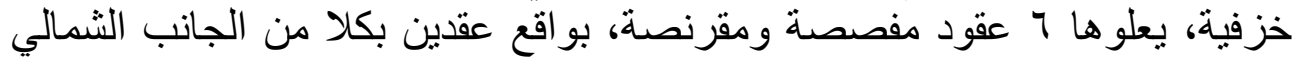
والجنوبي، وعقد بكلا من الجانب الثرقي والغربي. يؤطر جميع هذه العقود بشكل

9 TORRES BALBÁS, L.: Arte almohade, arte nazarí, arte mudéjar, Ars Hispaniae, IV, Madrid, 1949, p. 308; CANTERA Y BURGOS, F.: Sinagogas de Toledo, Segovia, y Córdoba, Madrid, 1973, pp. 174, 176.

10 AMADOR DE LOS RIOS Y VILLALTA, R., Monumentos arquitectónicos de España, pp. 281-283; CANTERA, F., MILLÁS, J. M. ${ }^{\text {, }}$ Las inscripciones hebraicas de España, Madrid, 1956, pp. 333-335, láms. VX-VXIII.

${ }^{11}$ AMADOR DE LOS RIOS Y VILLALTA, R., Monumentos arquitectónicos de España, pp. 316-323; SUAREZ QUEVEDO, D., "Toledo barroco", en: Arquitectura de Toledo. Del Renacimiento al Racionalismo, Toledo, 1992, pp. 261-262. 
متصل شريط من كتابات عربية منفذة بالحفر البارز على الجص بشكل تكراري

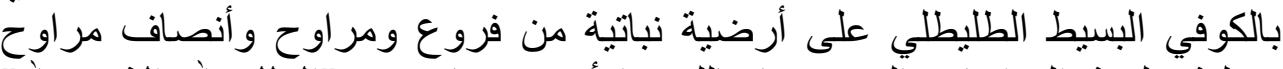

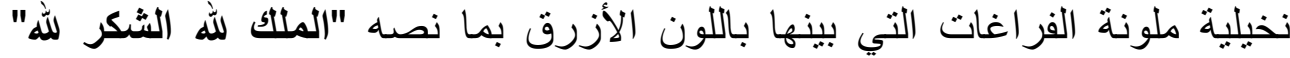

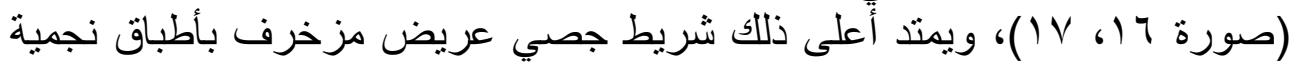

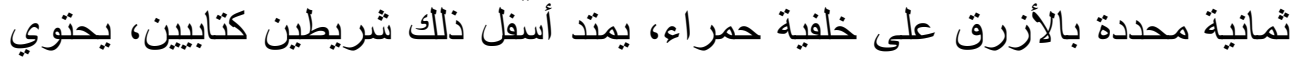

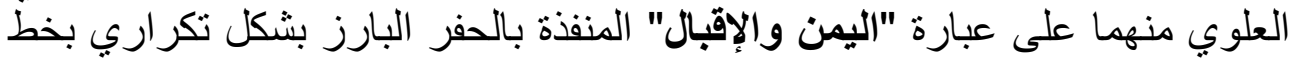

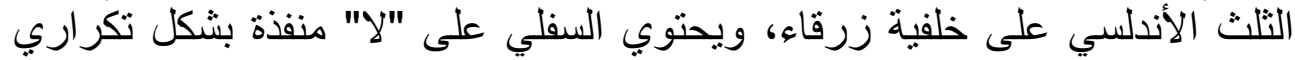

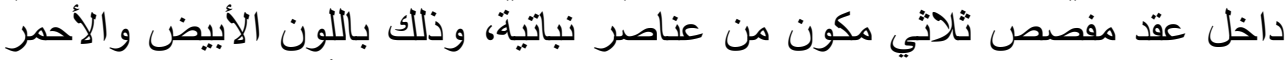

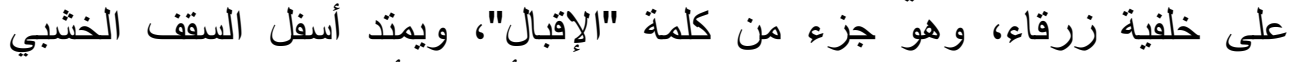

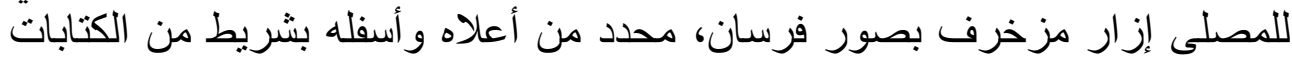

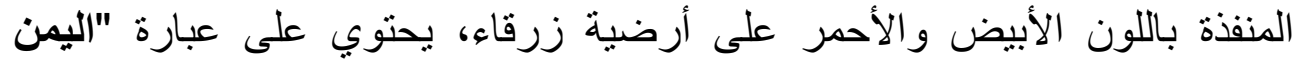



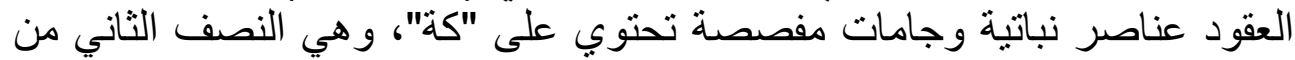

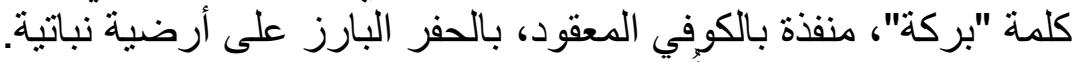

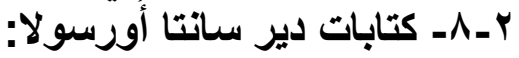

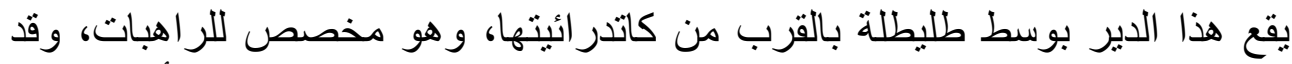

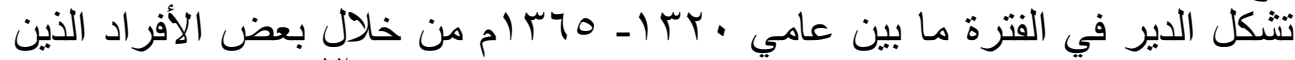

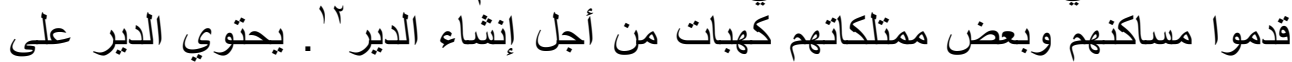

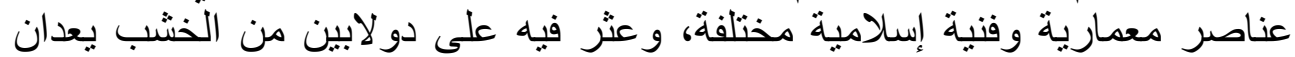

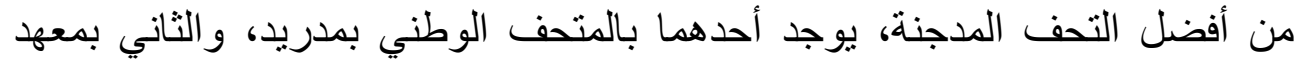
بلنسية دى دون خوان بمدريد، وتنتمي الأعمال المعمارية و الفنية و الكتابية الكتابات العربية

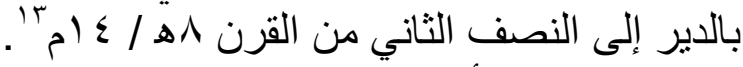

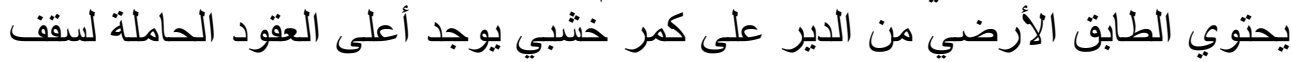

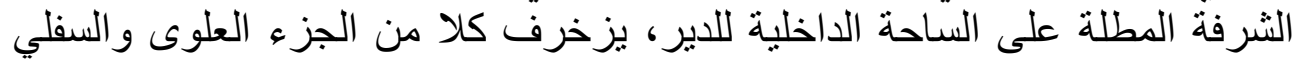
منه شريط من وحدات نباتية زخرفية منكررة منفذة بالحفر البارز، ولئه ويمتد أسفل

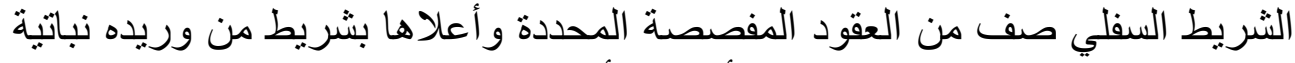

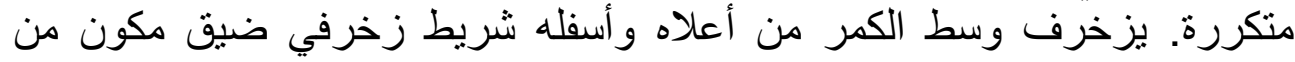

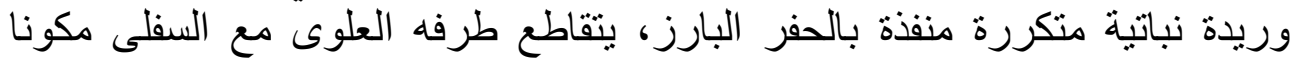

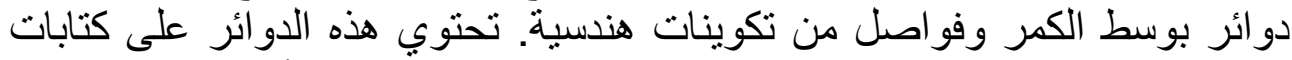

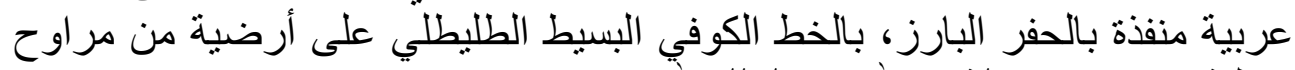

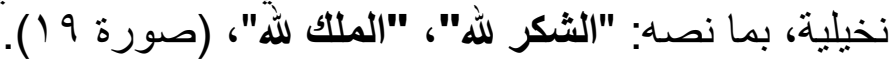

${ }^{12}$ PEREZ HigUeRA, T., "Convento de Santa Úrsula", en: Arquitectura de Toledo. Del Renacimiento al Racionalismo, Toledo, 1992, pp. 193-194.

${ }^{13}$ MARTÍNEZ CAVIRO, B., Mudéjar toledano, pp. 409-411, figs. 367-368. 
ץ ـ ـ ـ كتابات دير سان خوان دى لا بينيتينسيا:

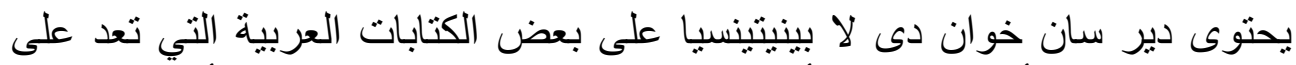

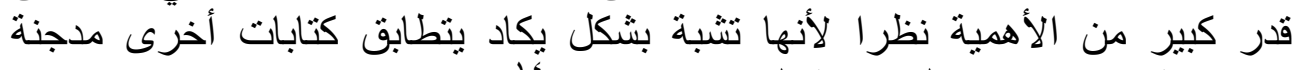

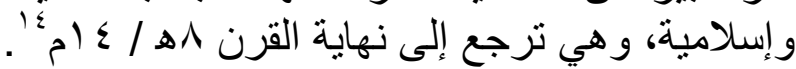

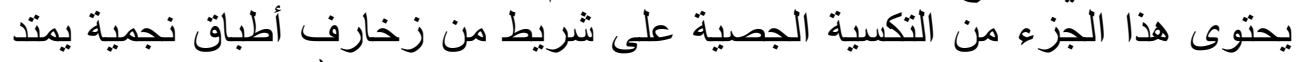

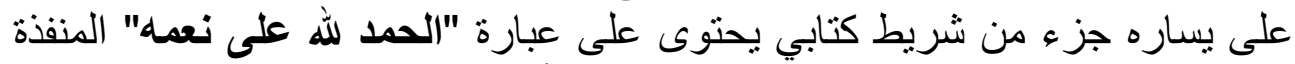

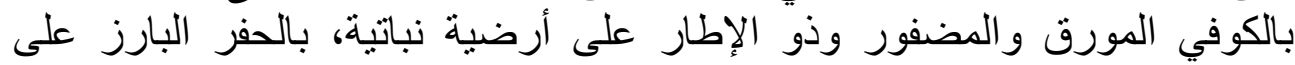

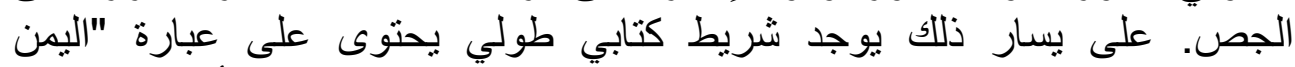

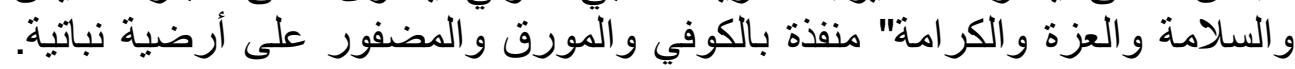

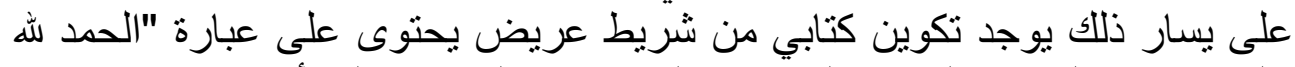

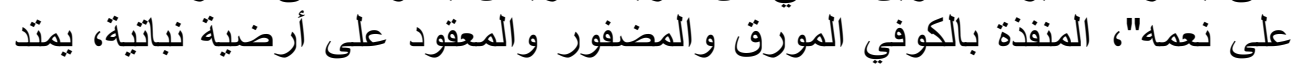

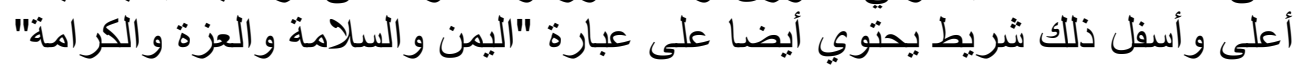

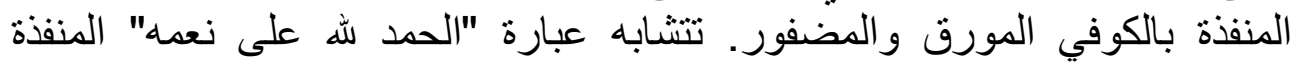

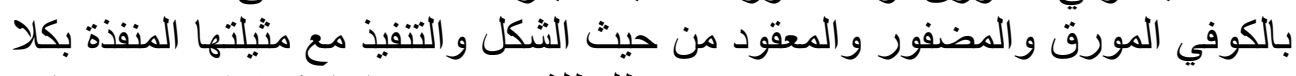

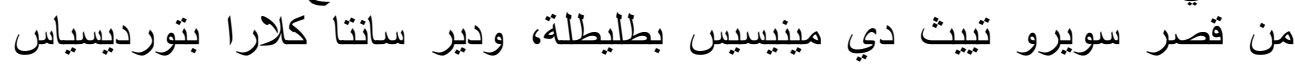

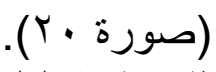

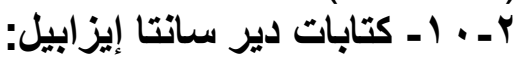

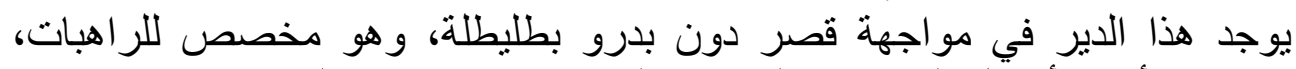

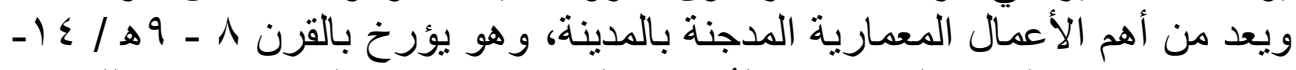

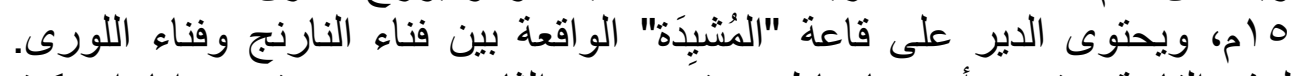

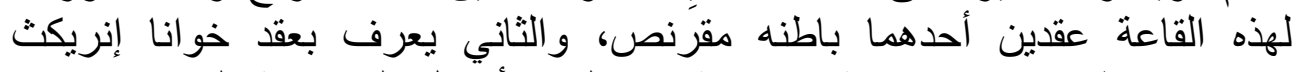

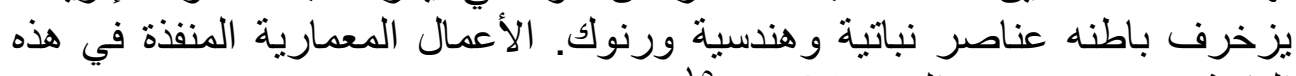

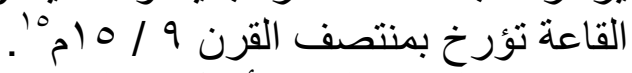

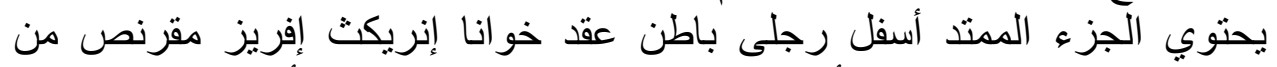

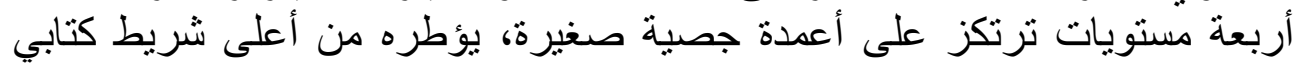

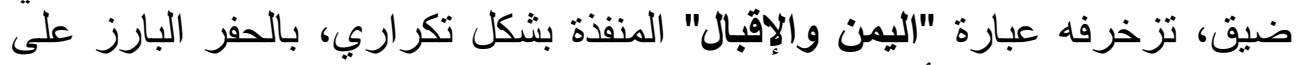

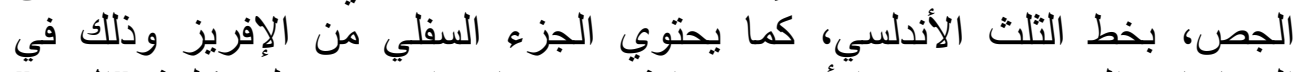

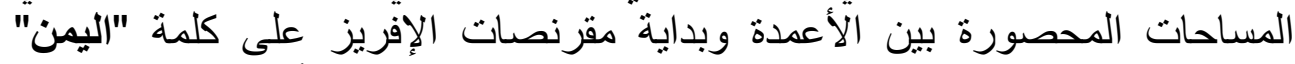

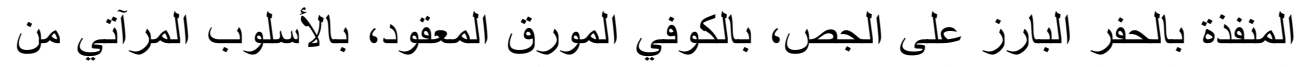

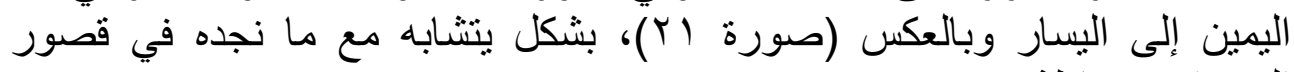
الحمر اء بغرناطنة.

${ }^{14}$ AMADOR DE LOS RIOS Y VILLALTA, R., Monumentos arquitectónicos de España, pp. 377-385; CONTRERAS, J. DE., Historia del arte hispánico, tomo 2, p. 457, fig. 476; MARTÍNEZ CAVIRO, B., Mudéjar toledano, pp. 199-200, fig. 170.

${ }^{15}$ MARTíNEZ CAVIRO, B., Mudéjar toledano, pp. 142-152, figs. 114, 120-122. 
يقع دير سان خوان الملكي بالقرب من كلان من المبان المعبدين اليهوديين سانتا ماريا

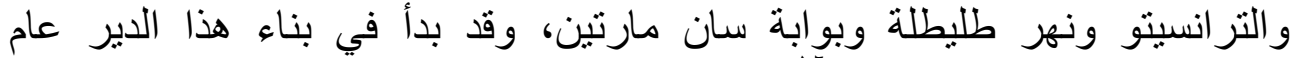
\&V9

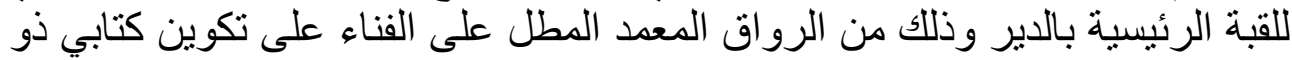

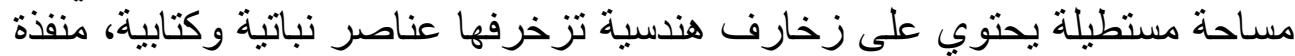

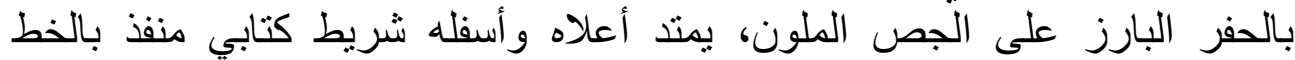

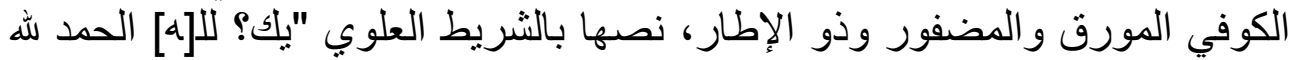

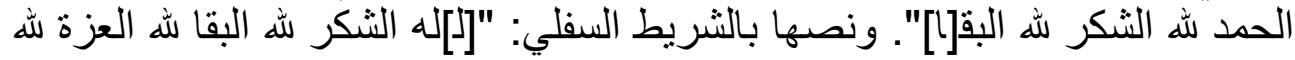

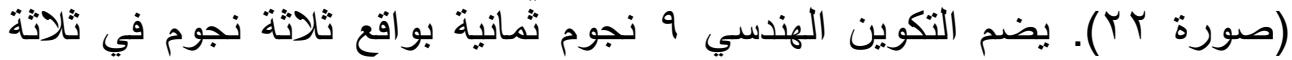

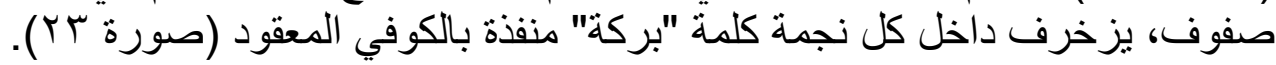

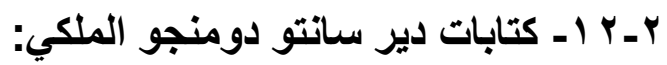

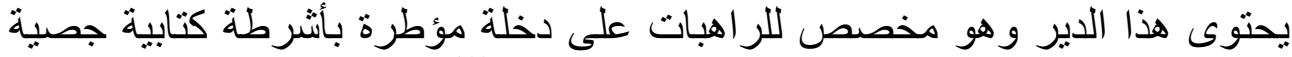

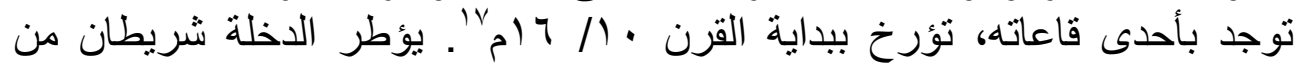

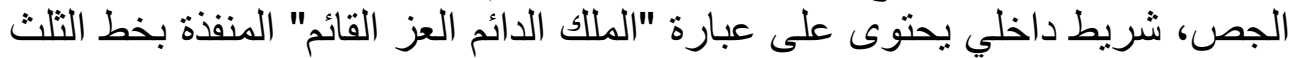

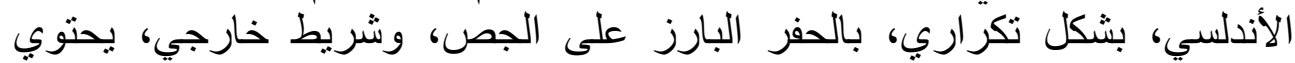

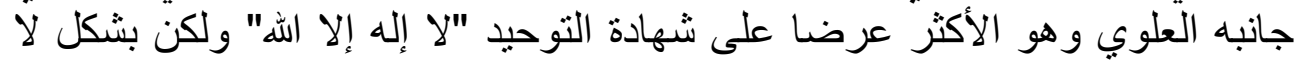
يخلو من المواراة، المنفذ ذلك بخط التلث على على أرضية نباتية التية، في حين أن كتابات

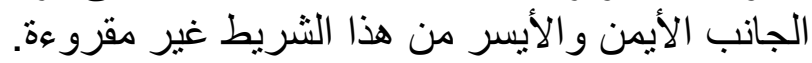

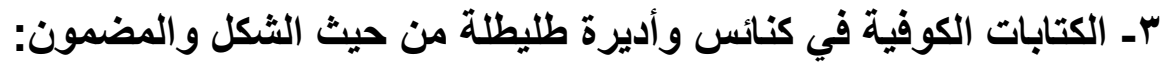

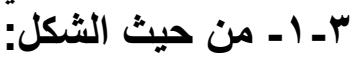

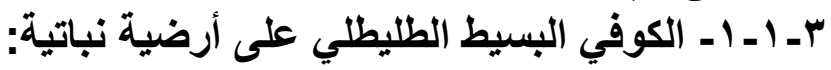

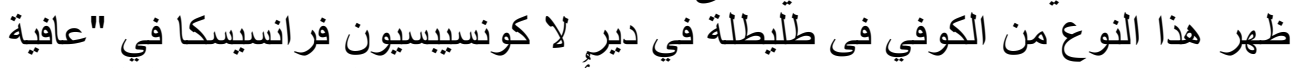

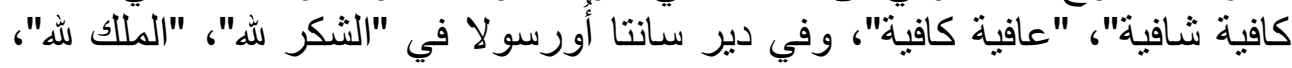

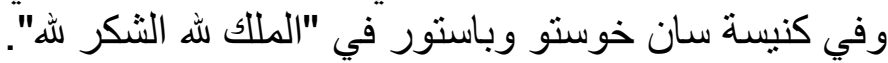
إستخدم الكوفي البسيط في الفن المدجن لكتابة العديد من العبار ات الدينية الدينية و الدعائية،

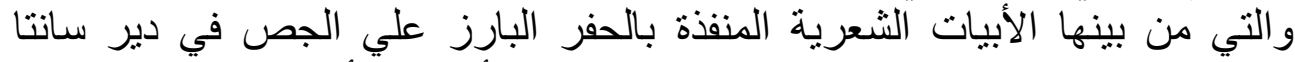

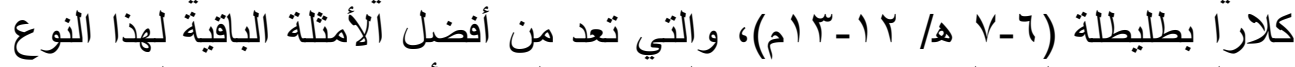

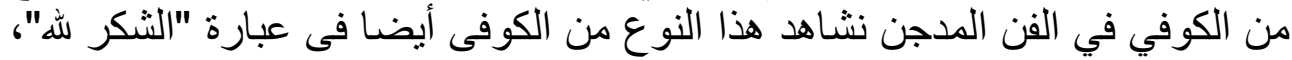

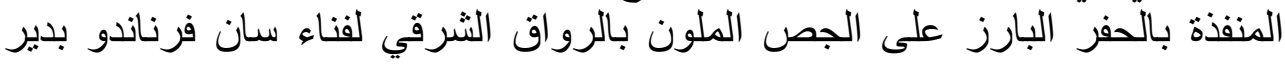

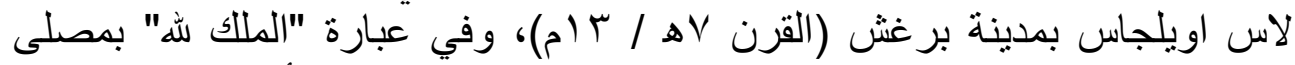

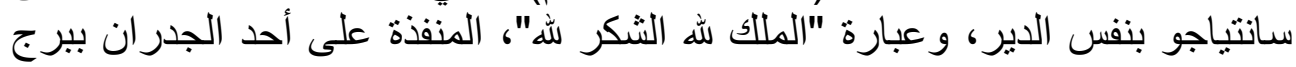

${ }^{16}$ FRANCO MATA, M. A., "Toledo gótico", 1992, pp. 489-502.

${ }^{17}$ MARTÍNEZ CAVIRO, B., Mudéjar toledano, pp. 385, 388, fig. 359. 
إيرقولس بشقوبية (القرن ^ هـ/ ع (م)، و عبارات "الحمد لله العزة لله الملك لله الثكر

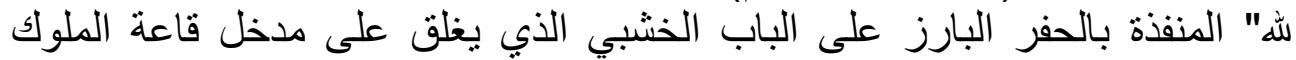

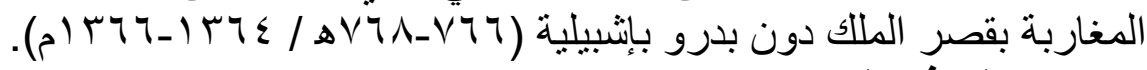

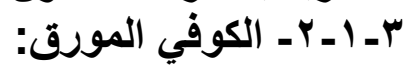
ظهر هذا النوع من الكوفي في كنيسة سان أندرس في عبار ات "النكر الله الملك لله الحمد لله، العزة لله"، وفي معبد التر انستو في "المئ الملك لله".

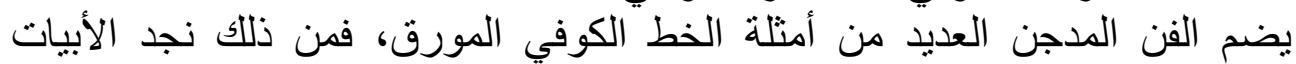

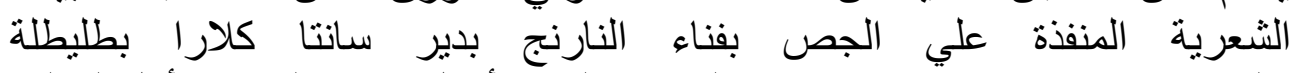



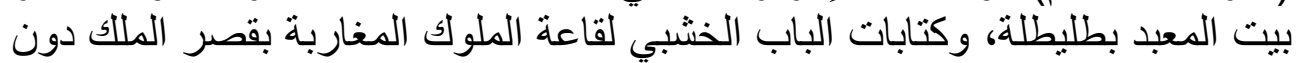

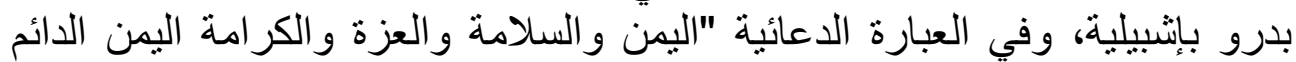

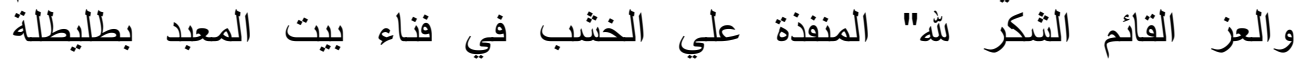

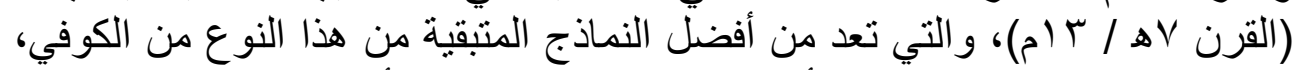

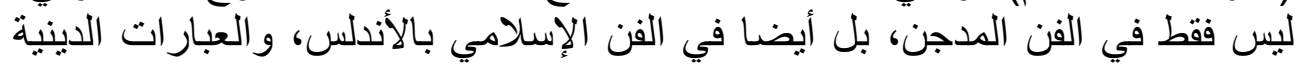

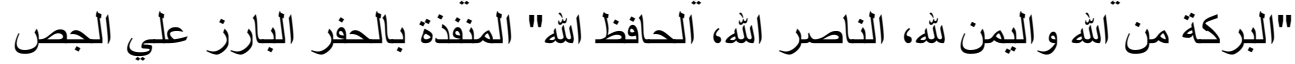

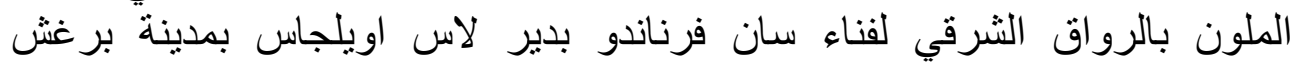

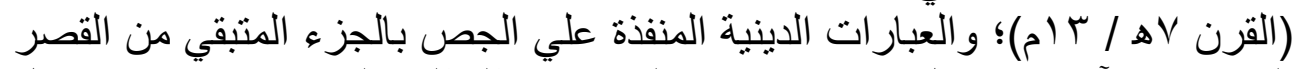

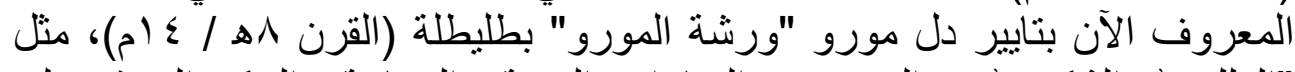

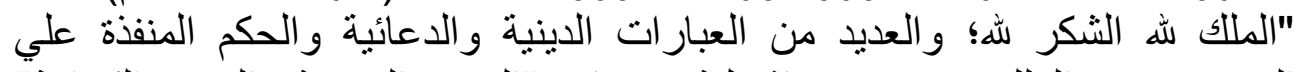

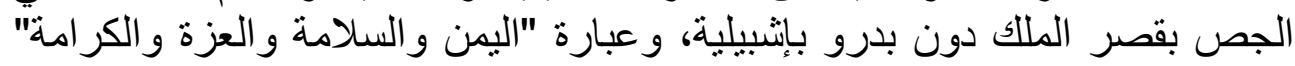

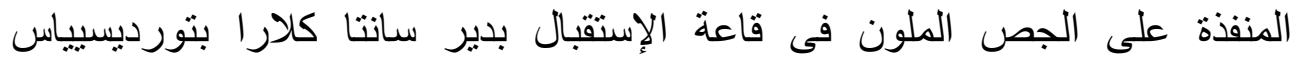

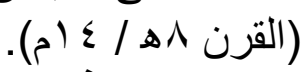

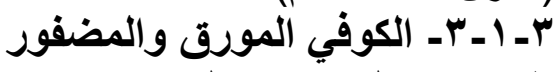

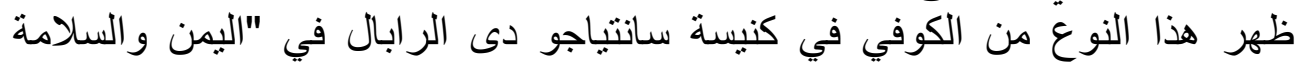

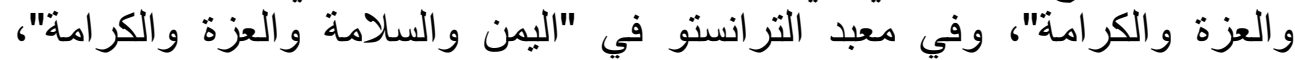

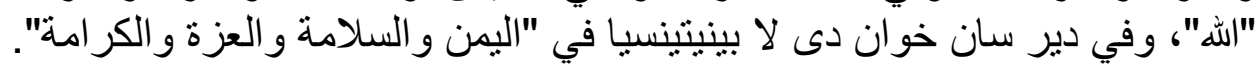

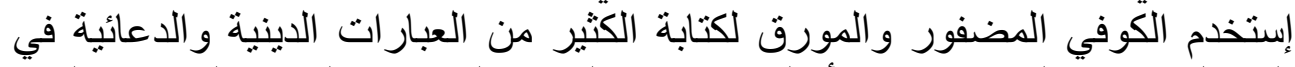

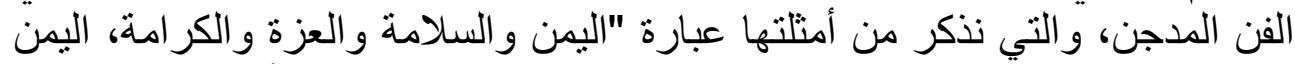

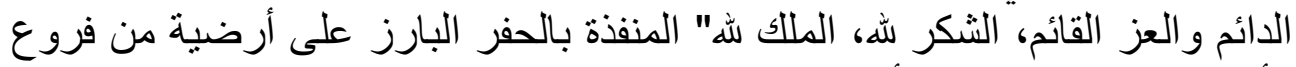

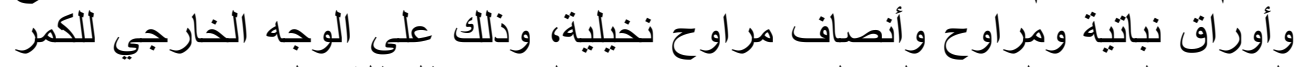

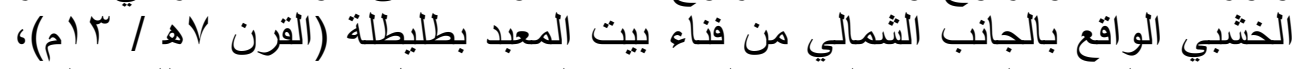

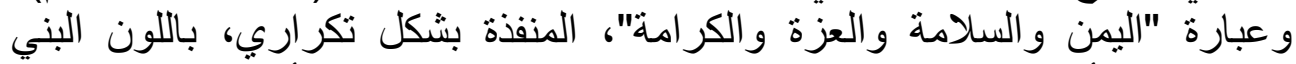

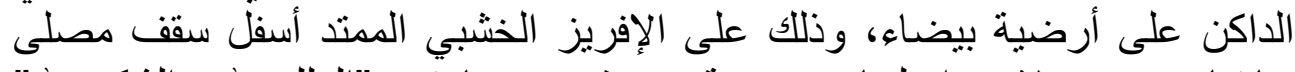

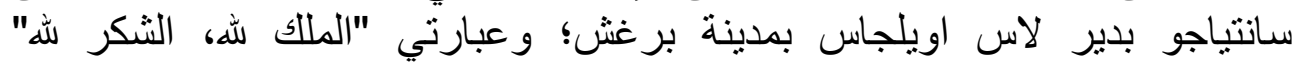
المنفذتين بالحفر البارز علي الحجر، وعبارة "النعمة الثأملة" المنفذة بالحفر البارز 


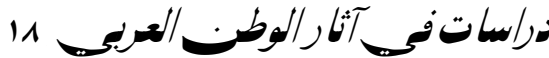

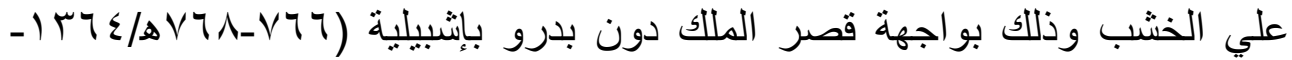

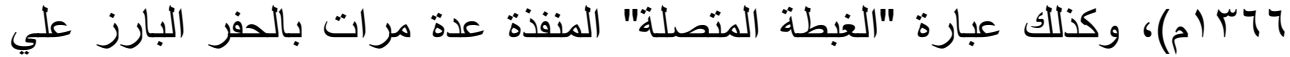

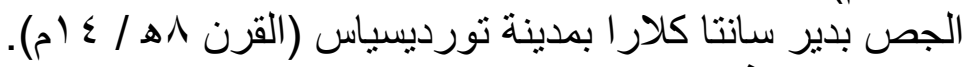

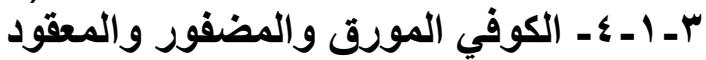

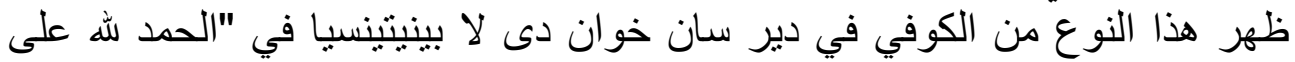

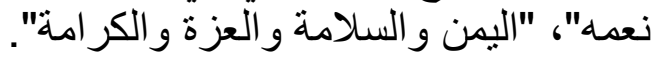

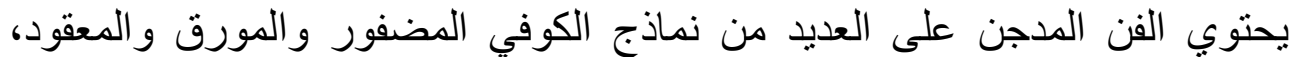

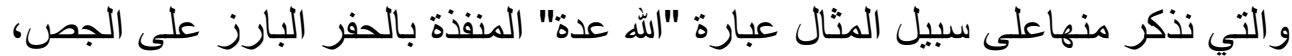

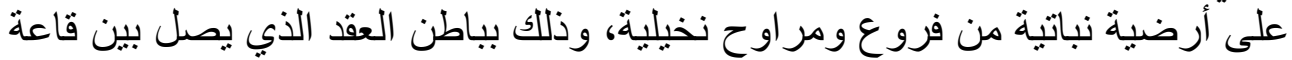

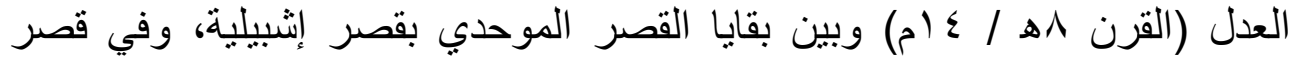

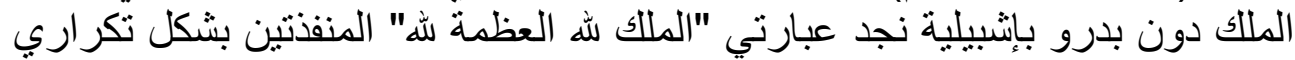

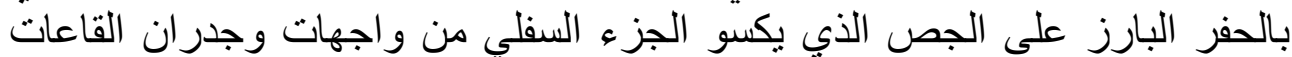

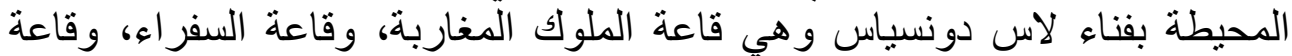

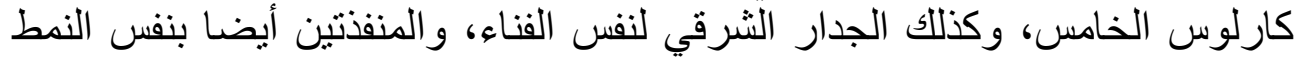



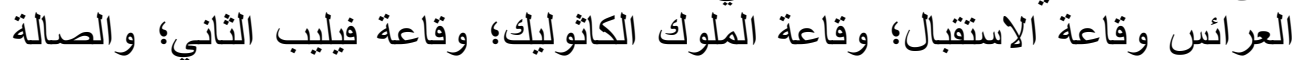

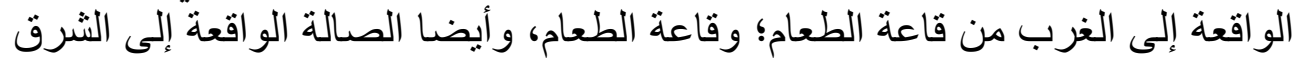

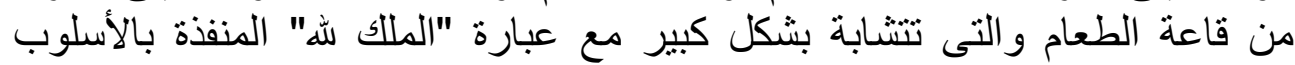

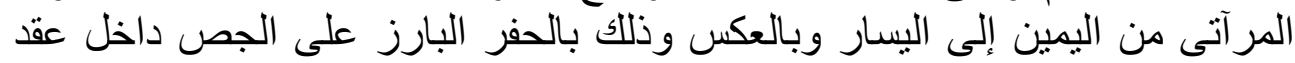

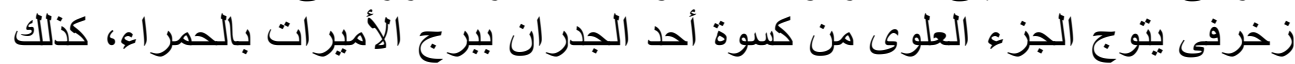

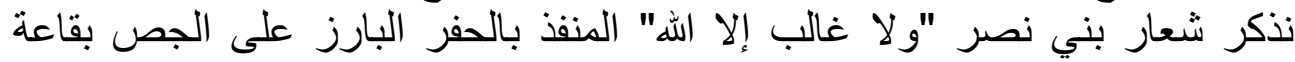

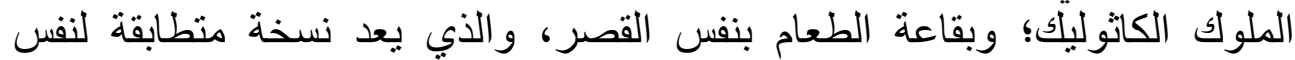

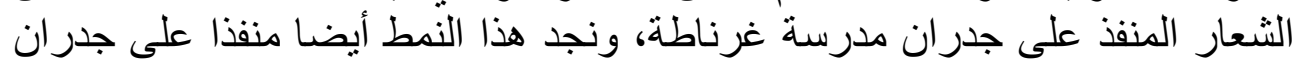

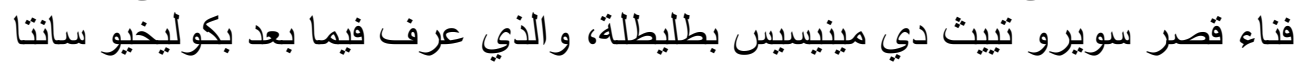

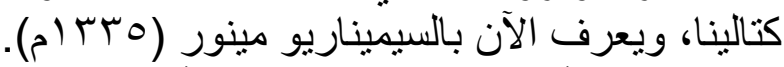

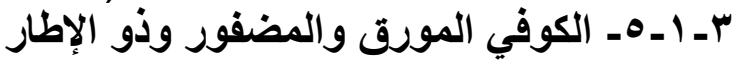

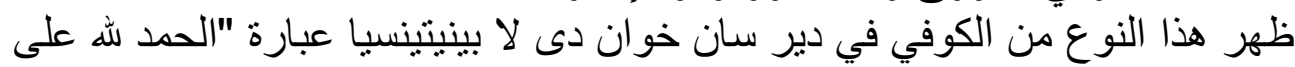

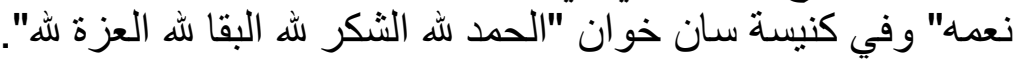

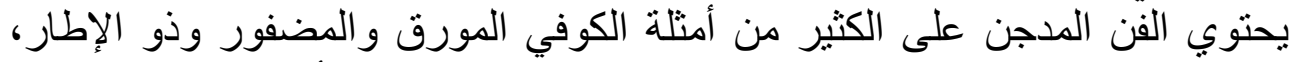

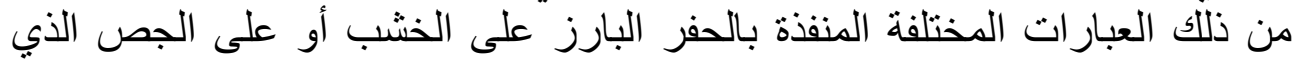

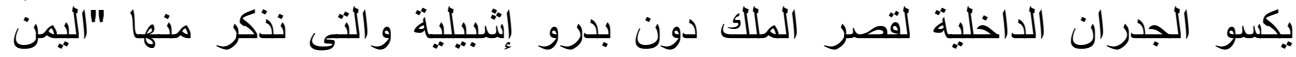

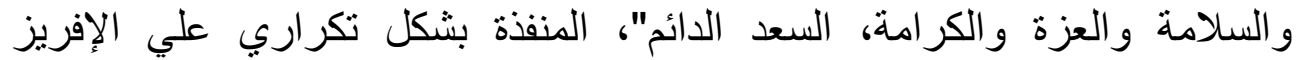

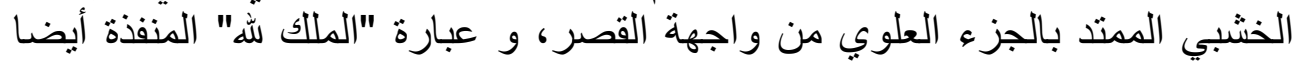

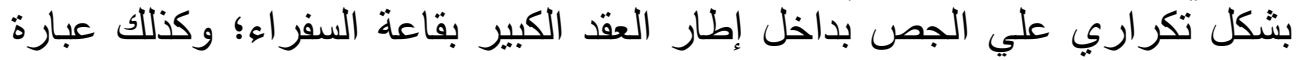




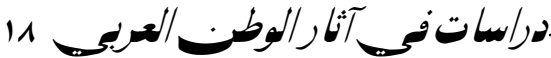

"عز لمو لانا السلطان ضن بدر أيده الله" المنفذة علي الجص بالأجز اء السفلية لجدران

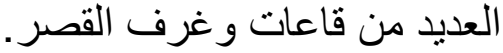

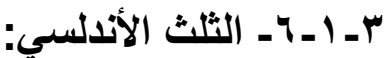
ظهر هذا النوع من الكوفي في معظم الكتابات المنفذة بكنائس وكاتدر ائيات طليطلة،

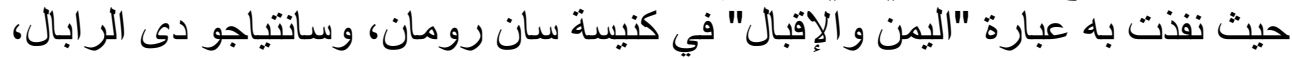

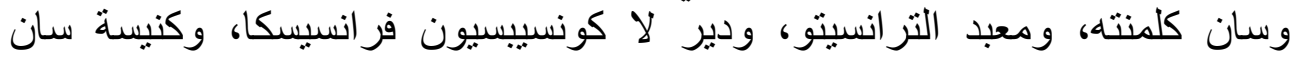
خوستو وباستور، ودير سانتا إيز ابيل،

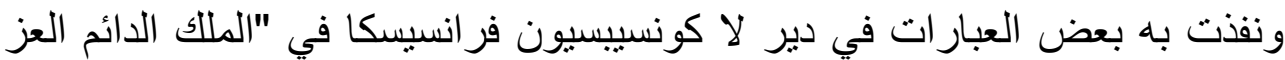

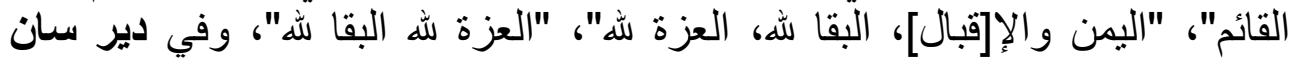

\section{خوان دى لا بينيتينسيا}

انتشر استخدام خط التثلث في الفن المدجن لتنفيذ العديد من الكتابات سواء كانت أشعار أو عبار ات دينية ودعائية، ويمكن أن نشاهد ذلك في معظم الكتابات المنفذة

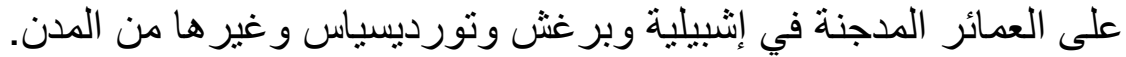

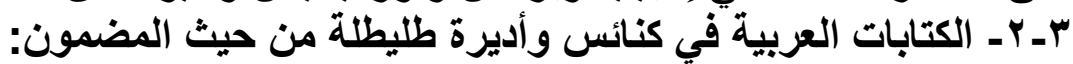

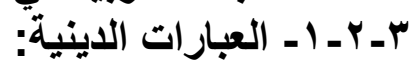

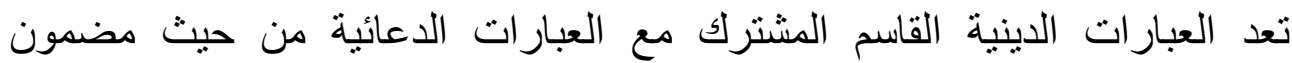

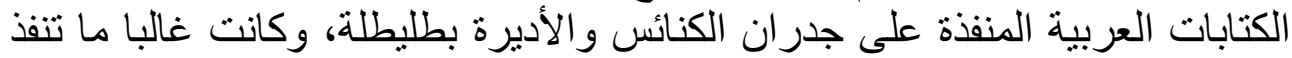

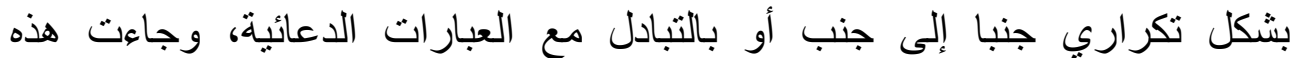

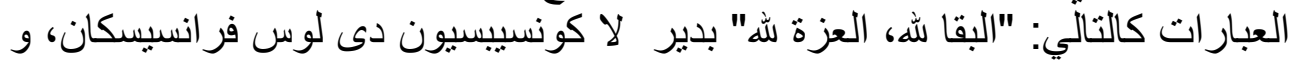

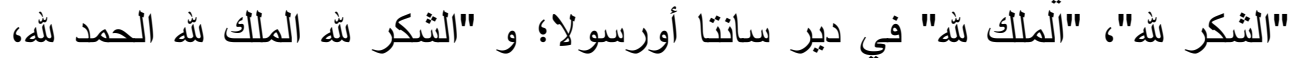
العزة لله" في كنيسة سان أندرس؛ و و "الحمد لله، الشكر لله، البقا لله، العزة لله" في لله كنيسة سان خوان.

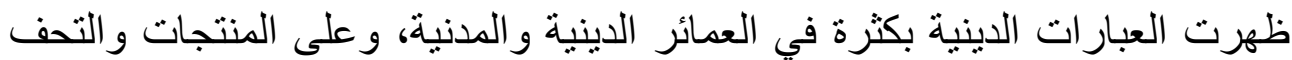

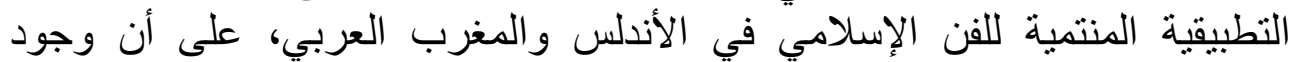

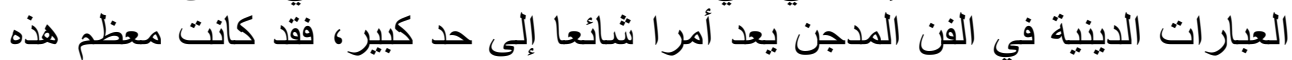

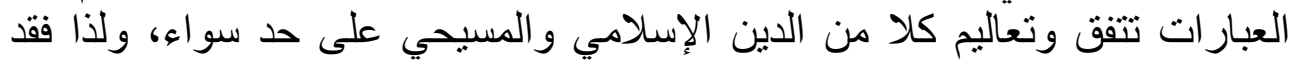

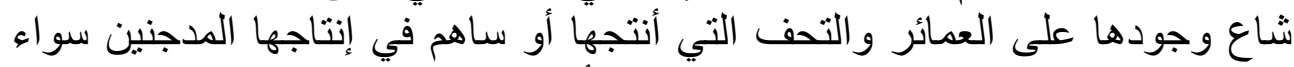

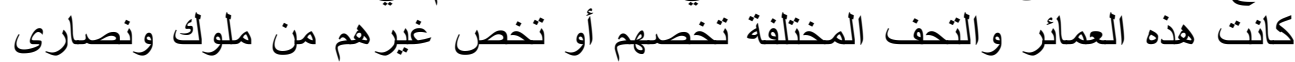



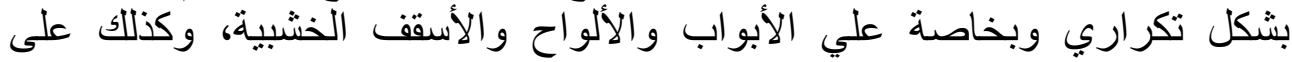

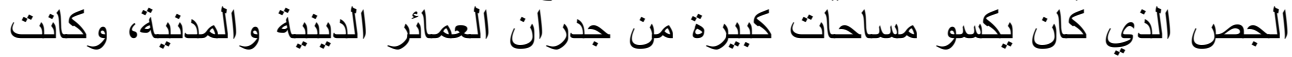

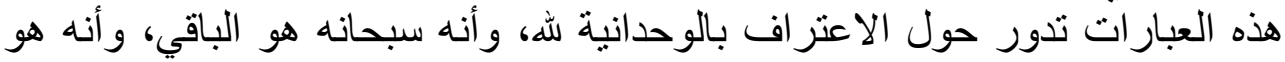

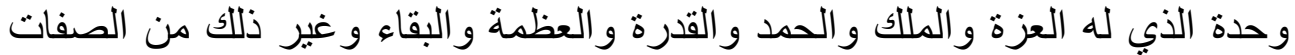

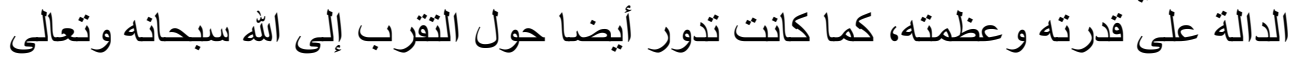
من خلال ذكر بعض العبارات التي تعترف بالثكر و الحمد لله، مثل عبارة "الحمد لله 
على نعمه"، ومن هنا نجد أن العبارات الدينية التي ظهرت في الفن المدجن هي

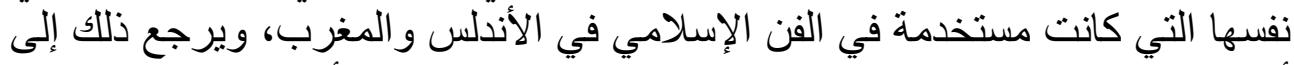

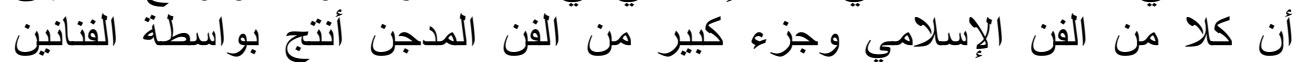

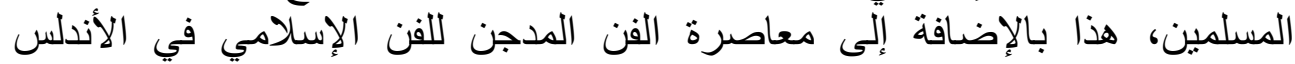

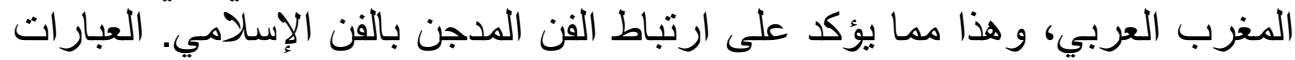

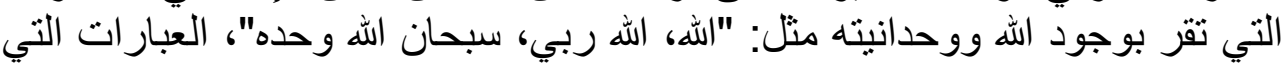

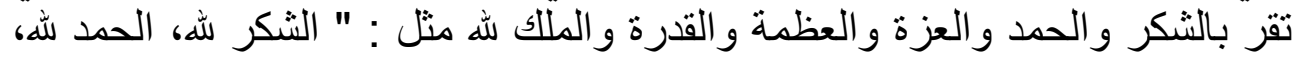

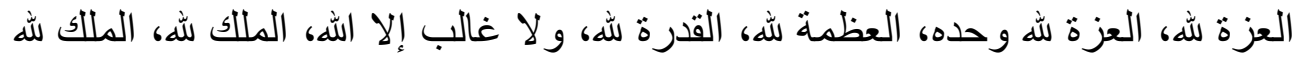

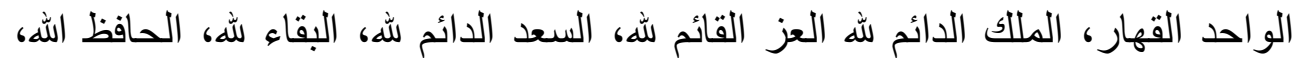
الحمد لله على نعمده".

من بين أمثلة العبارات الدينية في الفن المدجن نجد عبارة "الحمد لله على نعمده"

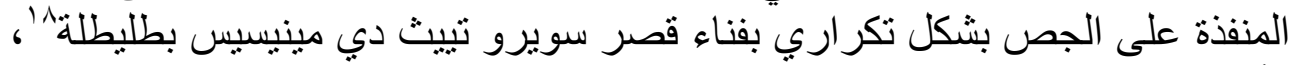

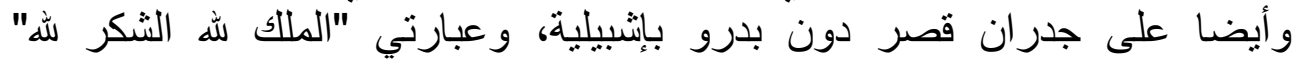

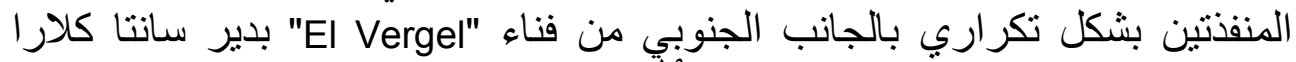

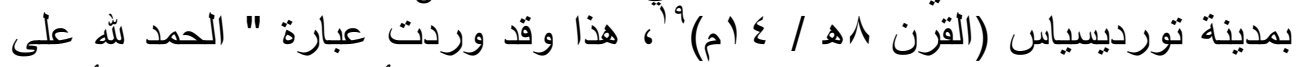

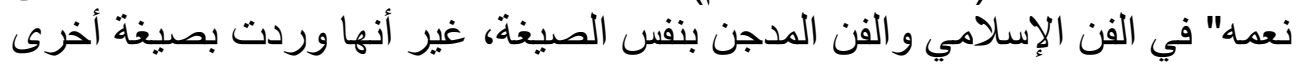

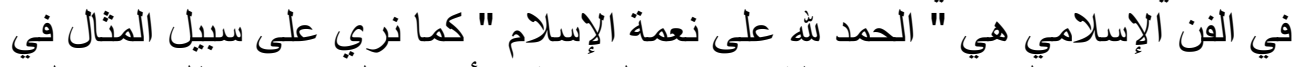

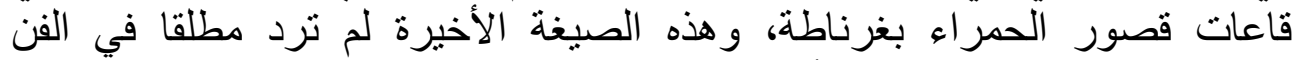

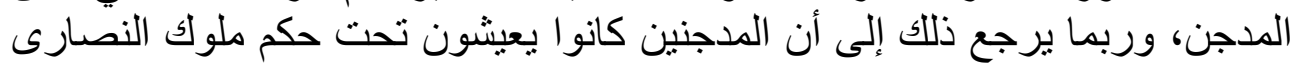

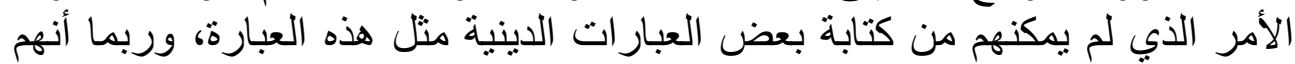

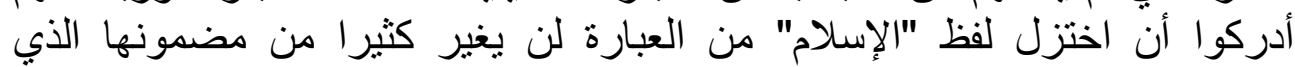

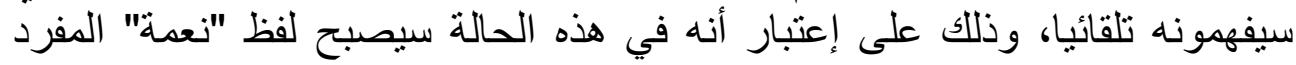

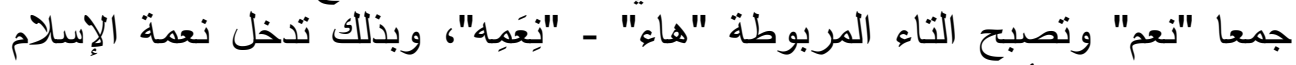

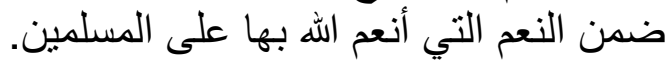

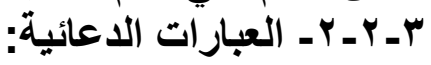

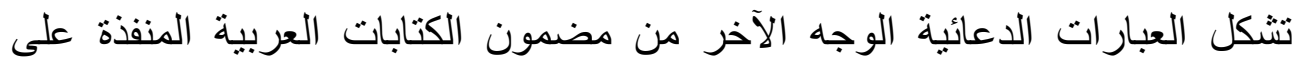

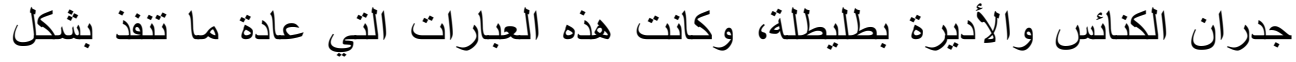

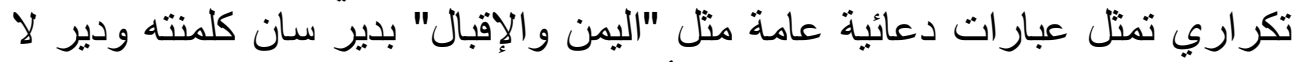

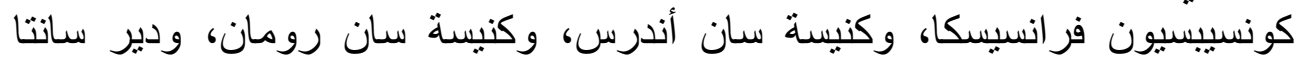

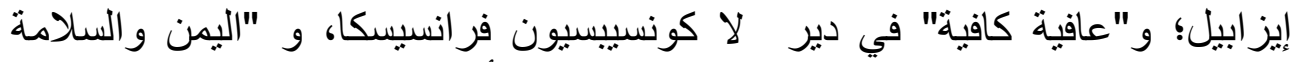

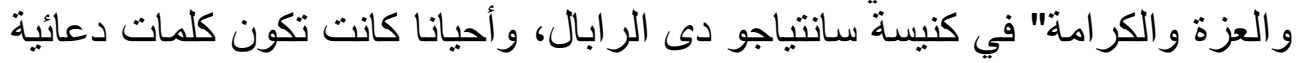

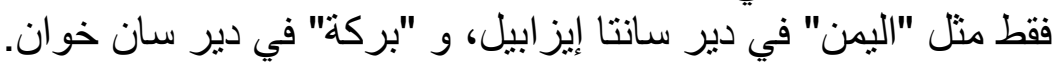

${ }^{18}$ MARTÍNEZ CAVIRO, B.: Mudéjar toledano. Palacios y conventos. pp. 409-410.

19 PÉREZ HIGUERA, T.: Arquitectura mudéjar en Castilla y León, Junta de Castilla y León, 1993, pp. 92- 94. 
أن معظم الكلمات و العبار ات ذات الصفة الدعائية التي نفذت على العمائر و التحف

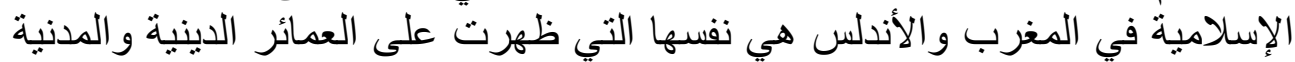

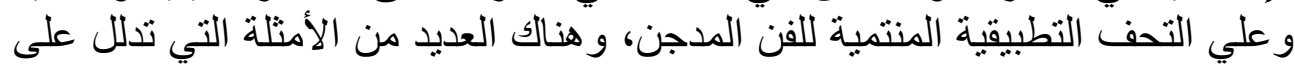

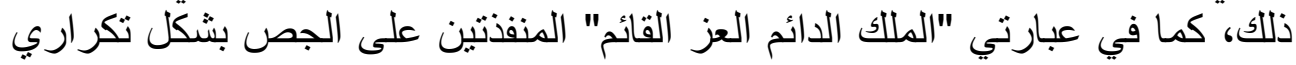

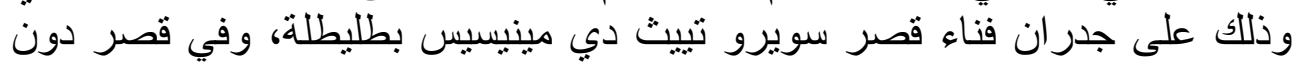

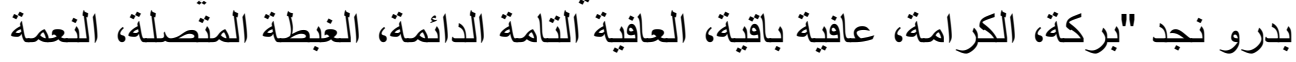

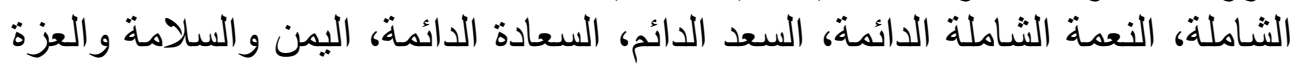
و الكر امة و السعد الدائم". ع - طرق تثفيذ الكتابات:

لم تخرج طرق تنفيذ الكتابات المدجنة في كنائس وأديرة طليطلة عن الأساليب

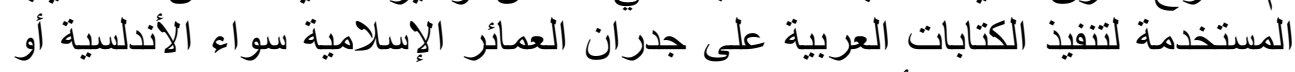



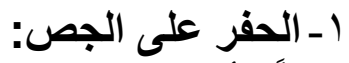

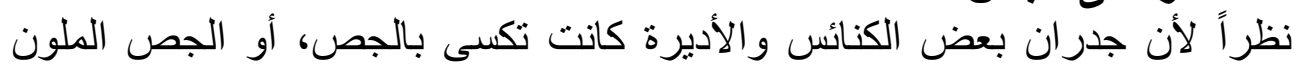

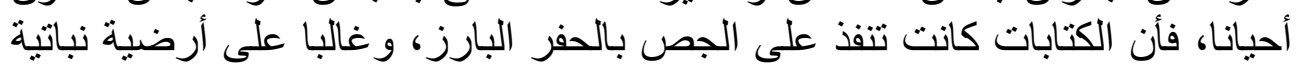

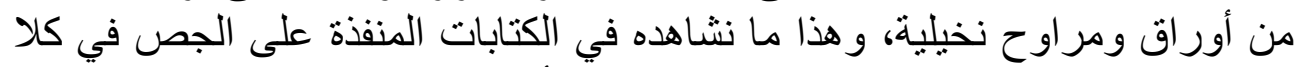

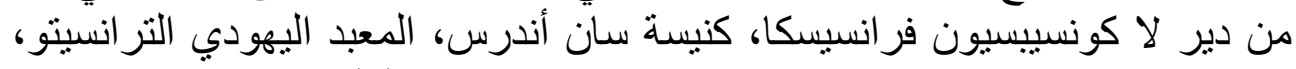

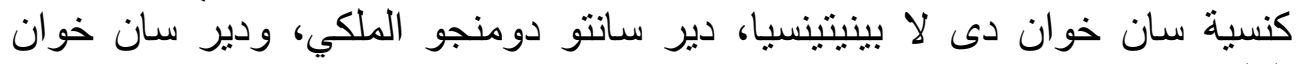
الملكي.

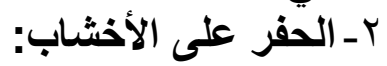
استخدم أسلوب الحفر على الخشى الخشب لتنفيذ بعض الكتابات في كنائس و أديرة طلبطلة

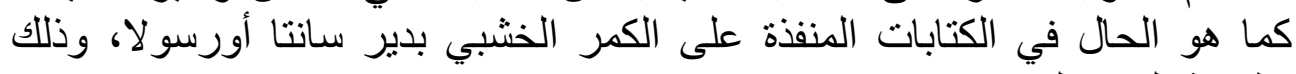

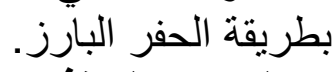

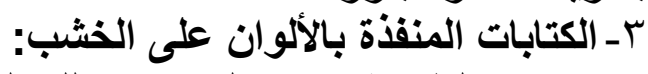

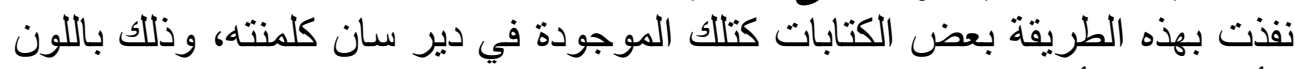

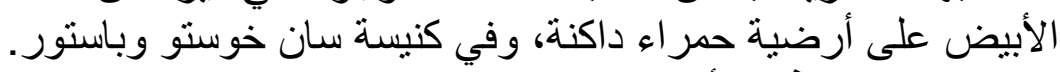

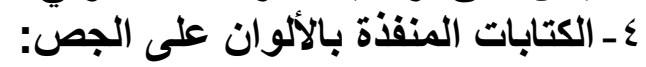

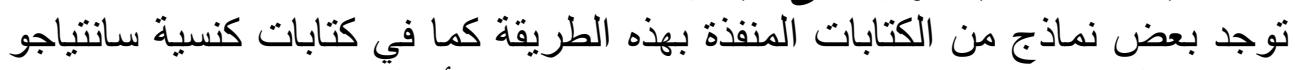

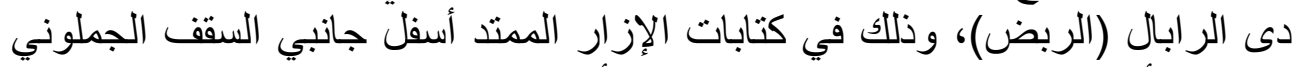

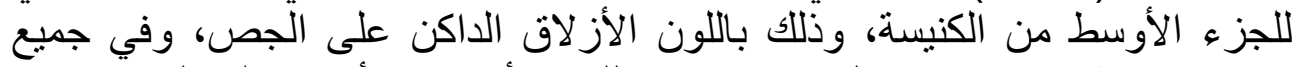

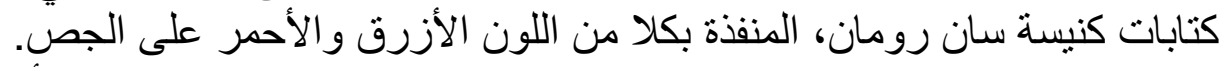

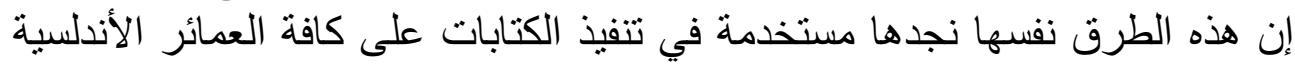

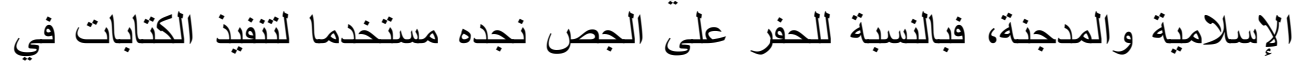

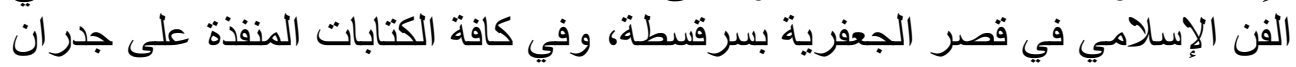

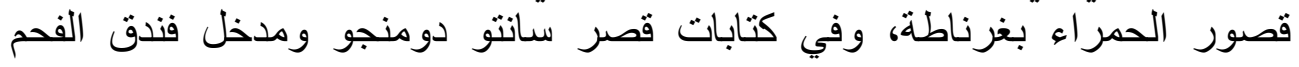


بغرناطة، وفي الفن المدجن نجده في الكتابات في دير لاس إويلجاس ببرغ غش، وفي وني

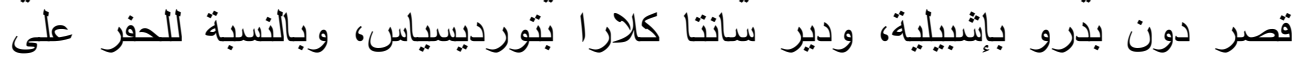

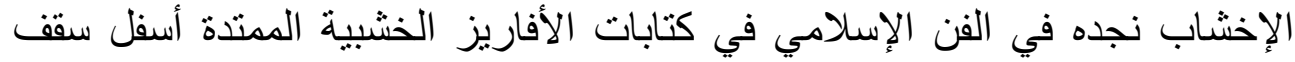

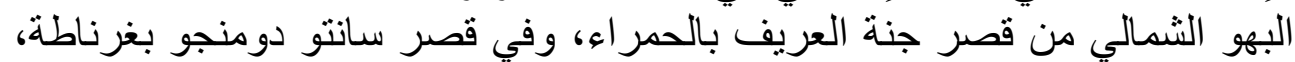

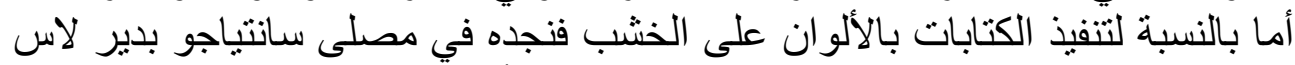

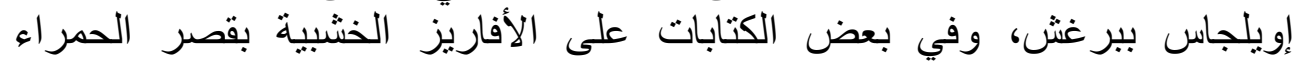
بغر ناطة.

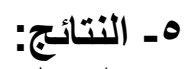
بعد التناول الميداني و الوصفي و التحليلي للكتابات العربية في كنائس و أديرة طليطلة يمكن تلخيص نتائج البحث في البي: ا ـتناول البحث موضو عالخ جديدا بالنسبة للار اسات الأثرية العربية المتعلقة بالأندلس،

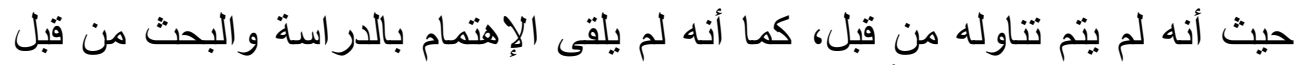

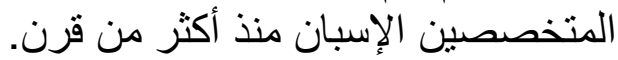

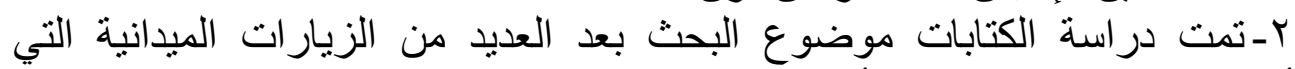



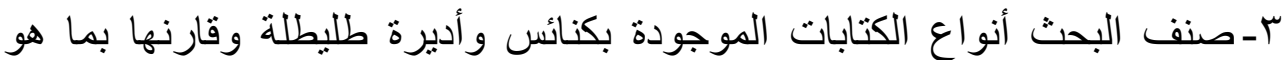
معاصر لها في الفن المدجن.

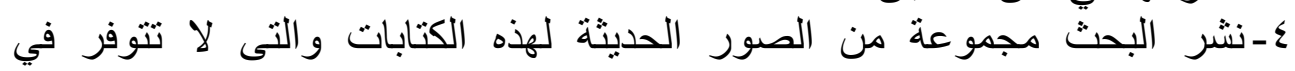
المر اجع الإسبانية الحديثة. هـتناول البحث بالإنة الدة استة والتحليل دراسة الكتابات من حيث الثكل والمضمون وأسلوب التنفيذ. 


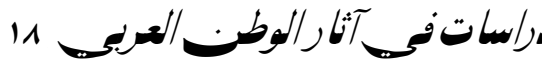
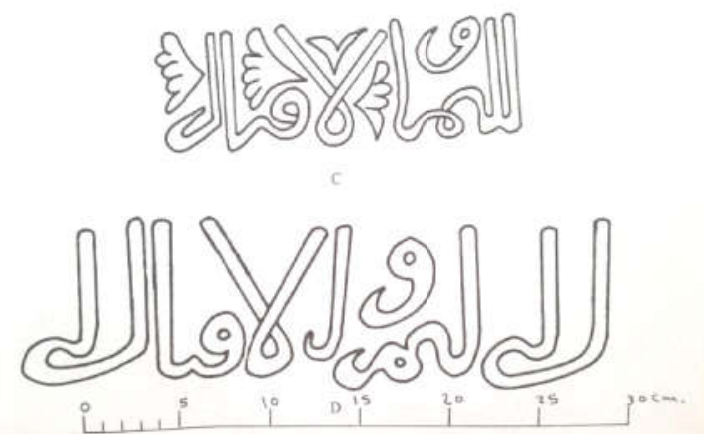

شكل ا : الكتابات العربية في دير لا كونسيسيون فرانسيسكا،



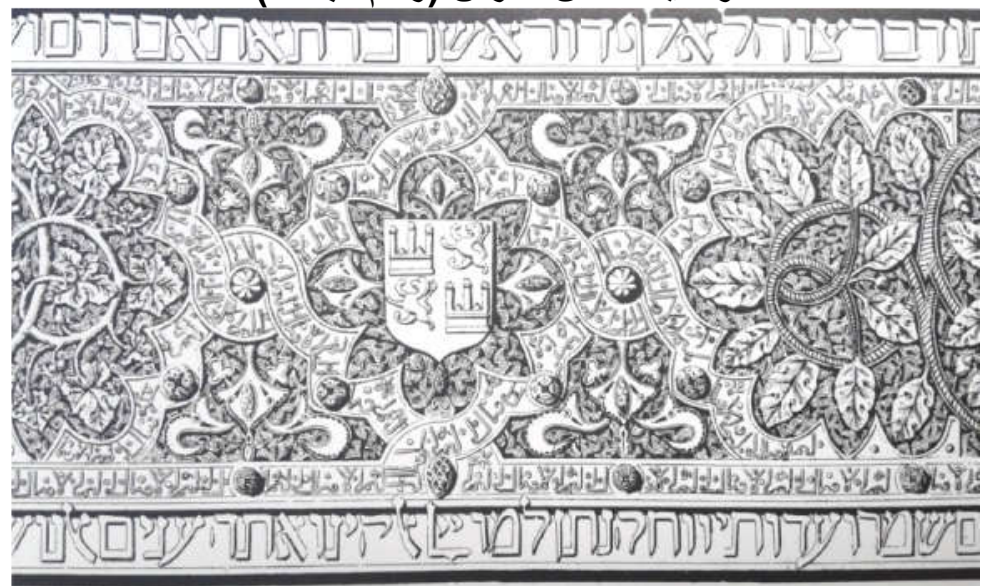

شكل ץ ب طليطلة، الكتابات العربية بمعبد الترانسيتو، (عن T. PEREZ HIGUERA).

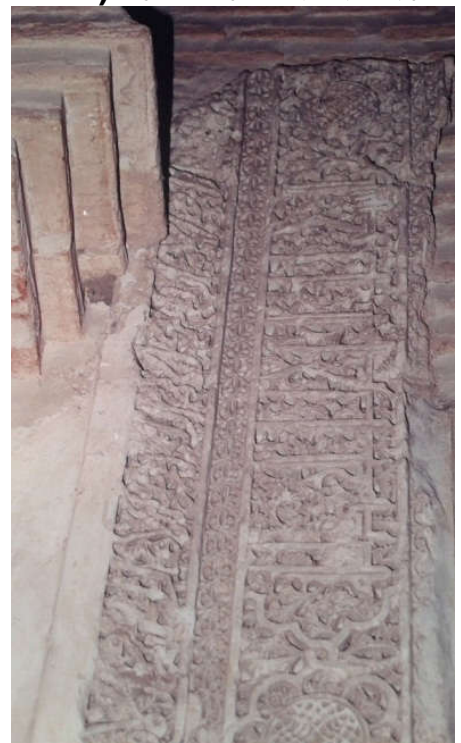

صورة ا : طليطلة، الكتابات العربية بكنيسة سان أندرس، (تصوير الباحث). 


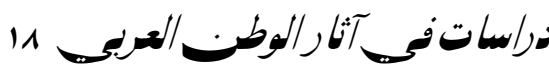

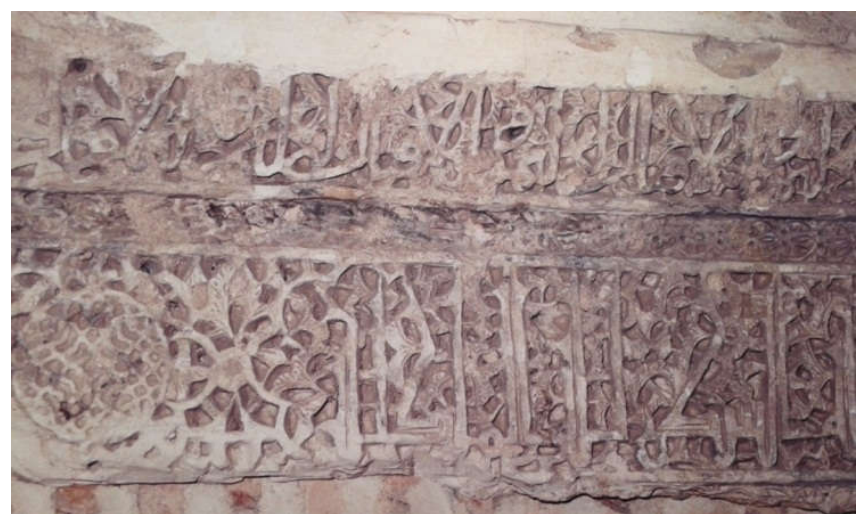

صورة ץ: طليطلة، الكتابات العربية بكنيسة سان أندرس، (تصوير الباحث).

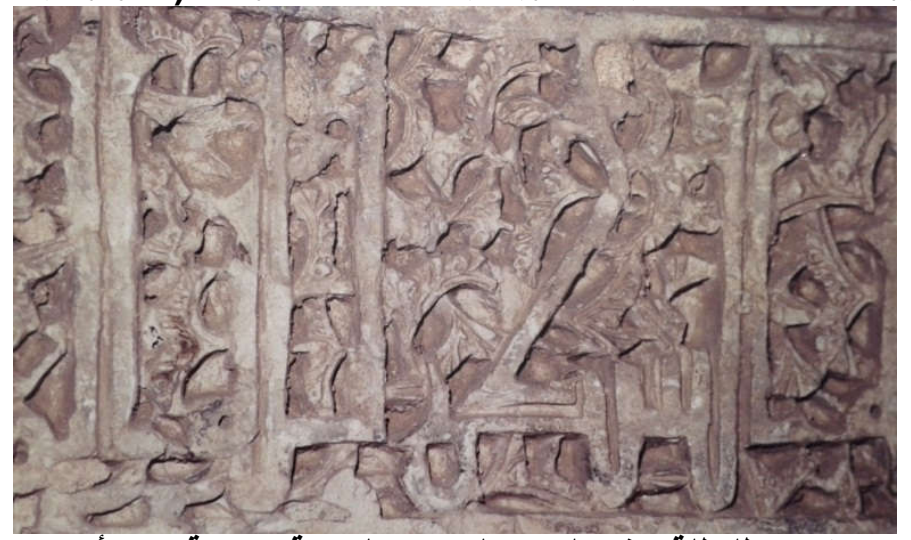

صورة ب: طليطلة، تفصيل من الكتابات العربية بكنيسة سان أندرس،

(تصوير الباحث).

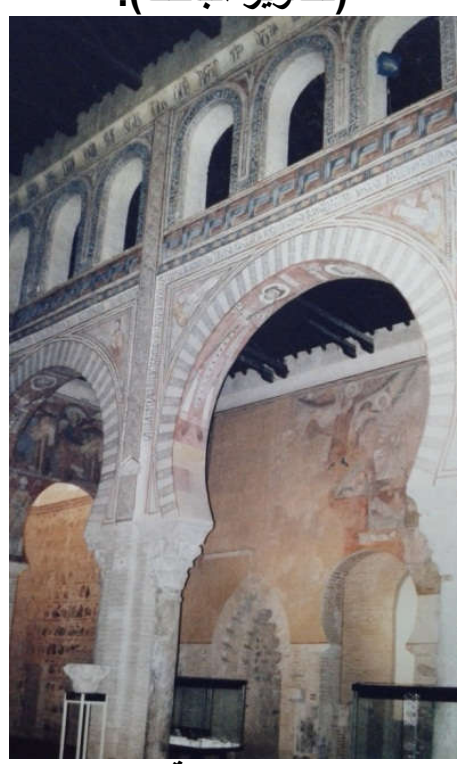

صورة ؛ : طليطلة، عقود البازليكا بكنيسة سان رومان، (تصوير الباحث). 


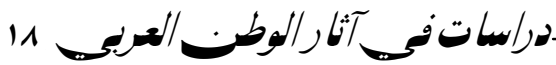

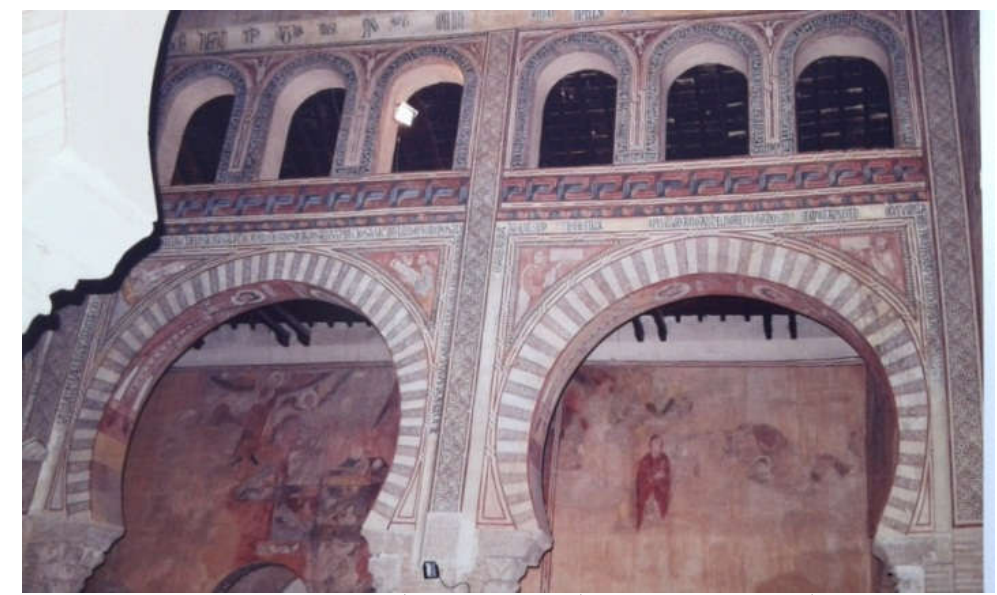

صورة ه: طليطلة، الكتابات العربية بعقود كنيسة سان رومان، (تصوير الباحث).

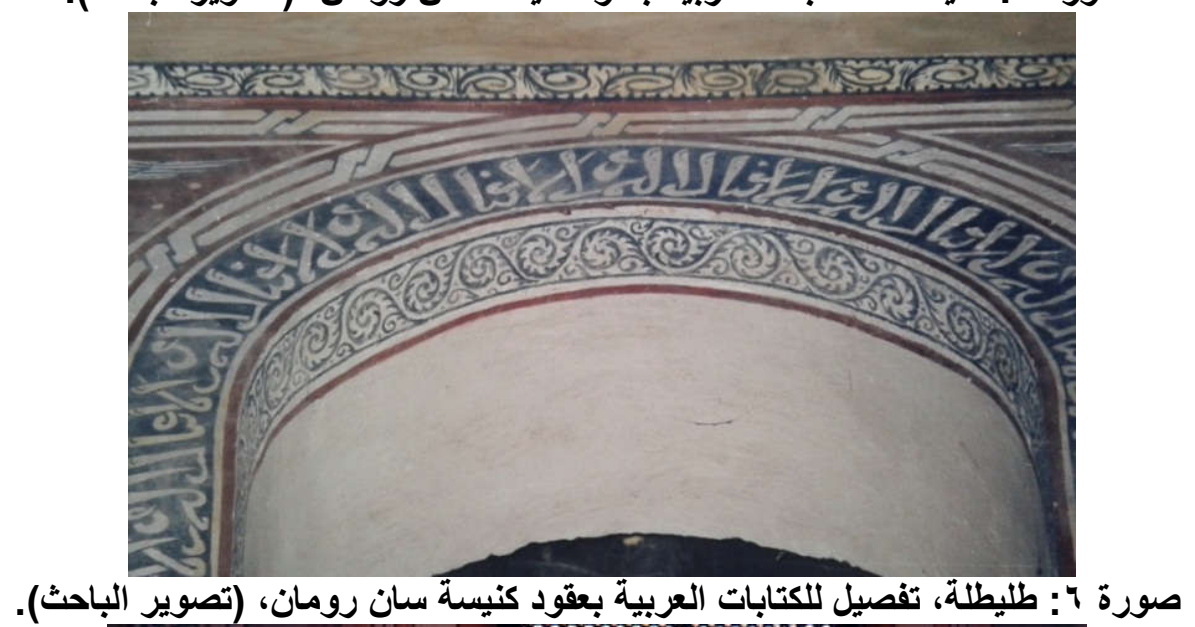

صورة 7 : طليطلة، تفصيل للكتابات العربية بعقود كنيسة سان رومان، (تصوير الباحث).

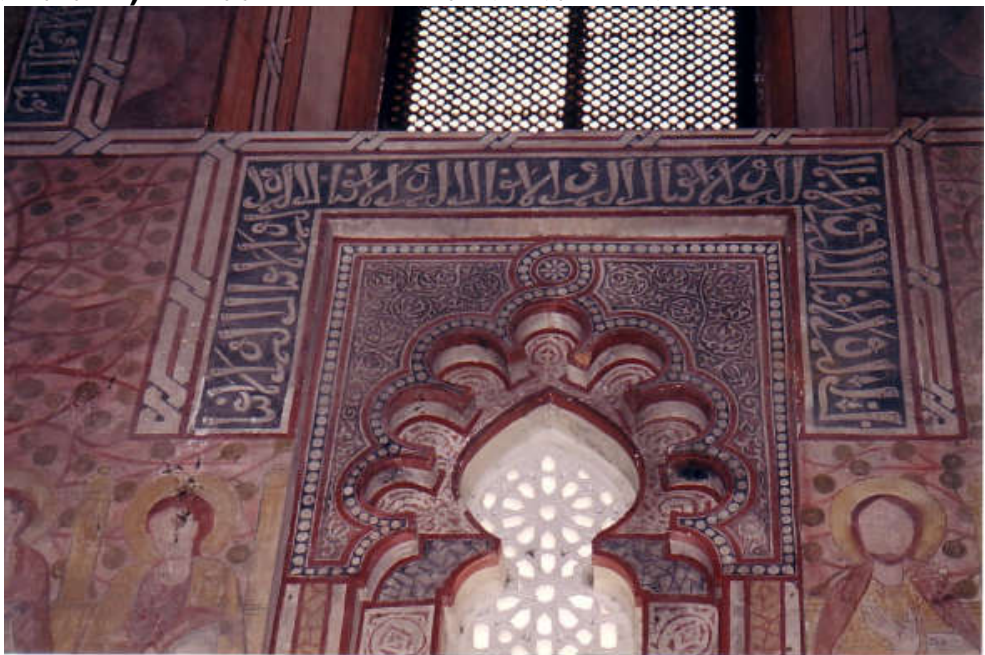

صورة V: طليطلة، الكتابات العربية بنوافذ كنيسة سان رومان، (تصوير الباحث). 


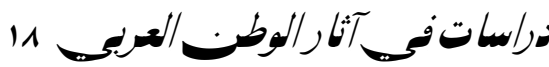

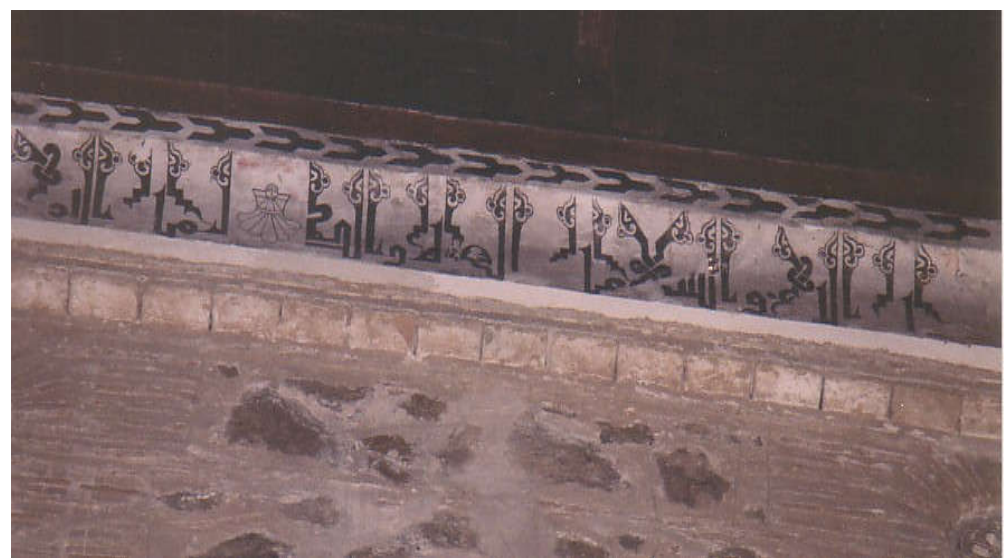

صورة ^: طليطلة، الكتابات العربية بكنيسة ساتتياجو دى الرابال، (تصوير الباحث).



صورة 9: طليطلة، الكتابات العربية باير لاكونسيبسيون فرانسيسكا، (تصوير الباحث).

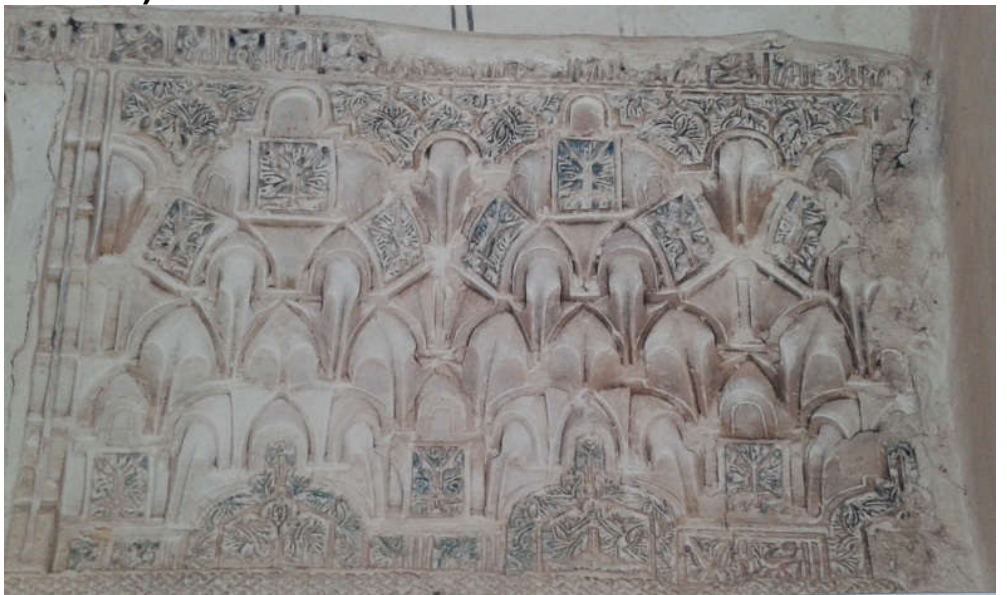

صورة • 1: طليطلة، الكتابات العربية بدير لاكونسيبسيون فرانسيسكا، (تصوير الباحث). 
11

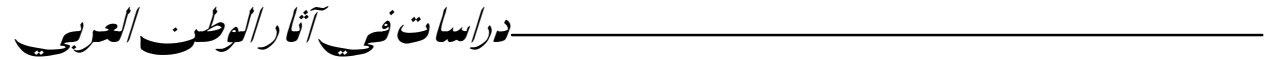

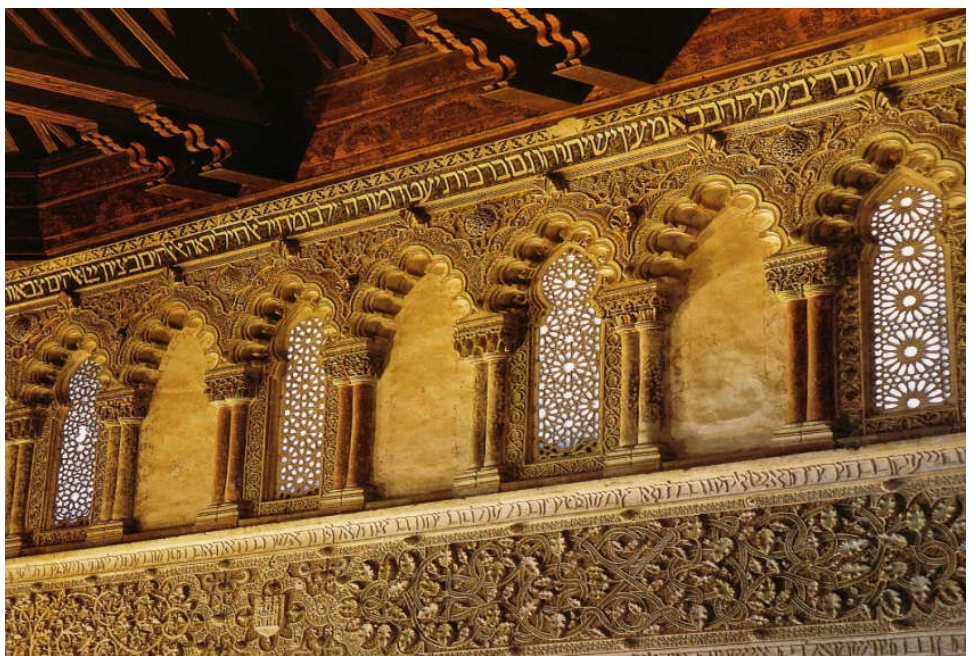

صورة 11: طليطلة، الصالة الرئيسية بمعبد الترانسيتو.

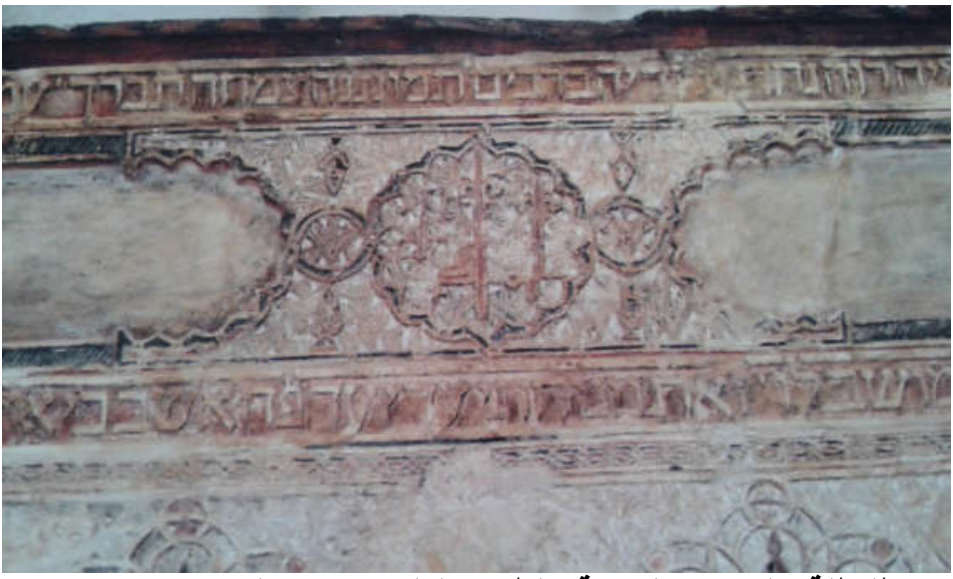

صورة r 1 : طليطلة، الكتابات العربية بالطابق العلوي بمعبد الترانسيتو، (تصوير الباحث).

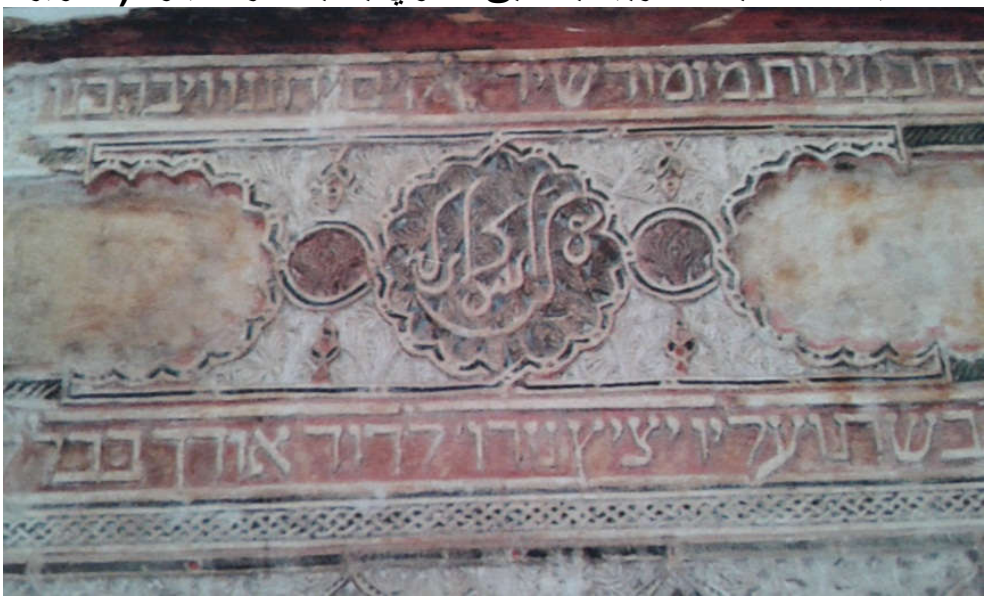

صورة س 1 : طليطلة، الكتابات العربية بالطابق العلوي بمعبد الترانسيتو، (تصوير الباحث). 

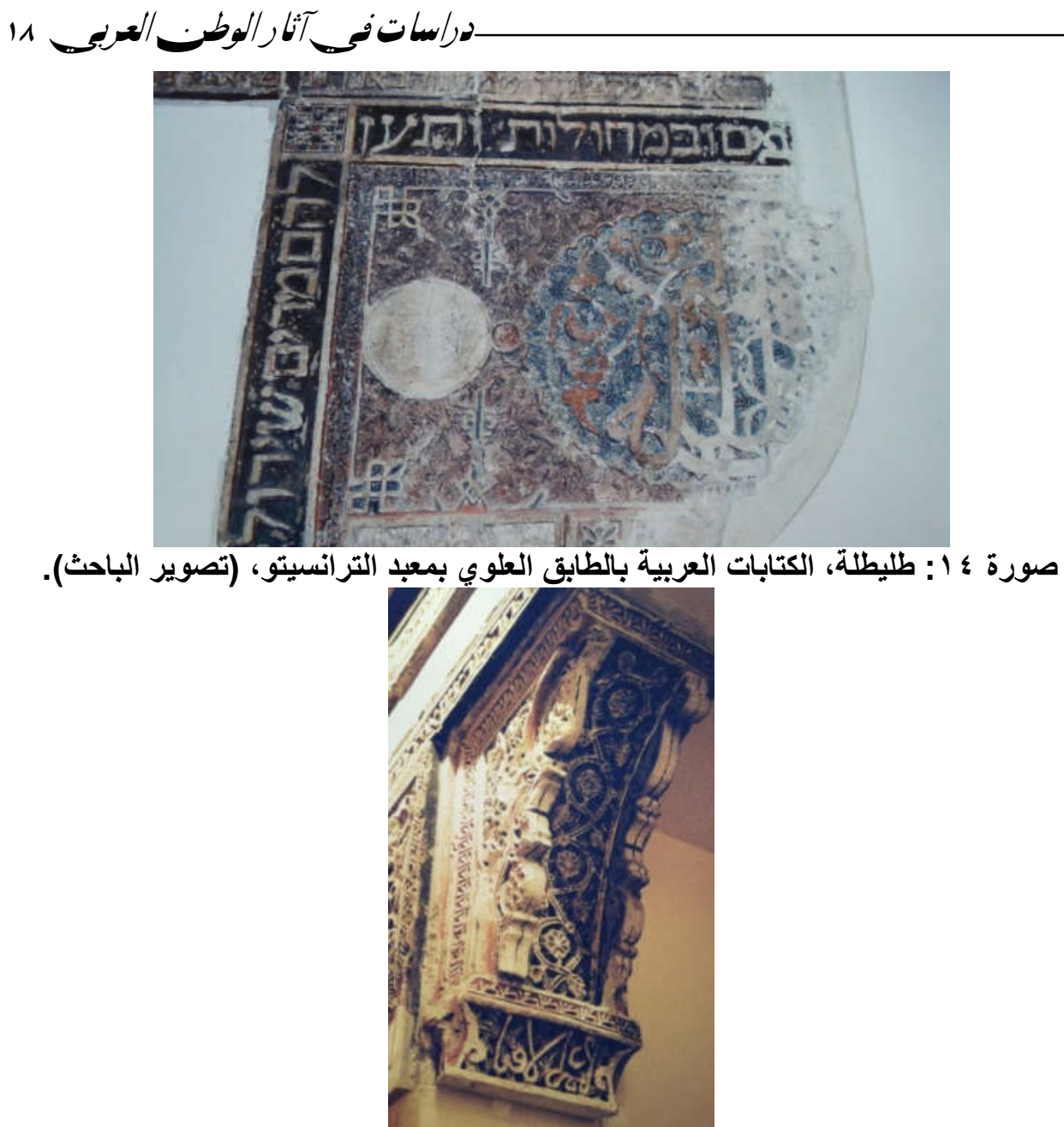

صورة ه 1 : طليطلة، الكتابات العربية بالطابق العلوي بمعبد الترانسيتو، (تصوير الباحث).

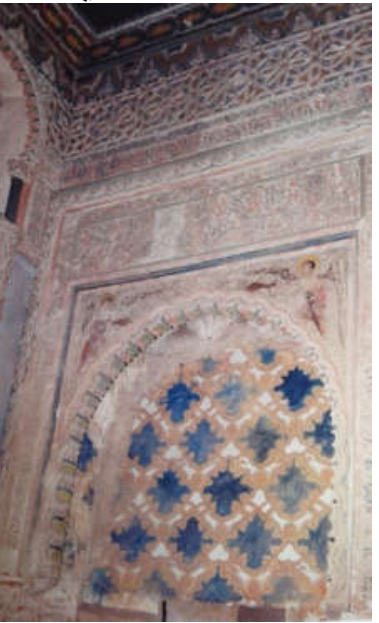

صورة 7 ا : طليطلة، كنيسة سان خوستو و باستور، (تصوير الباحث). 


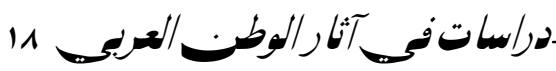

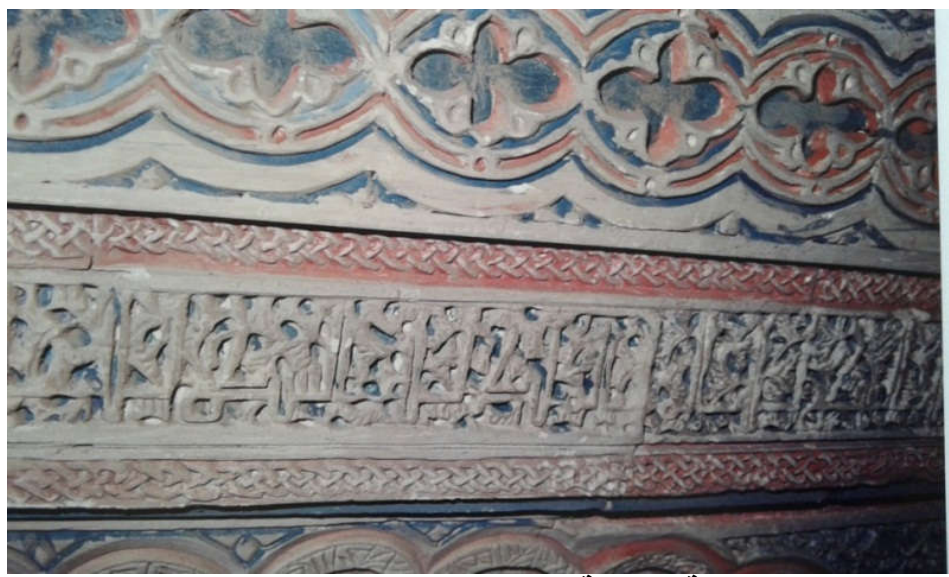

صورة V l : طليطلة، كنيسة سان خوستو و باستور، (تصوير الباحث).

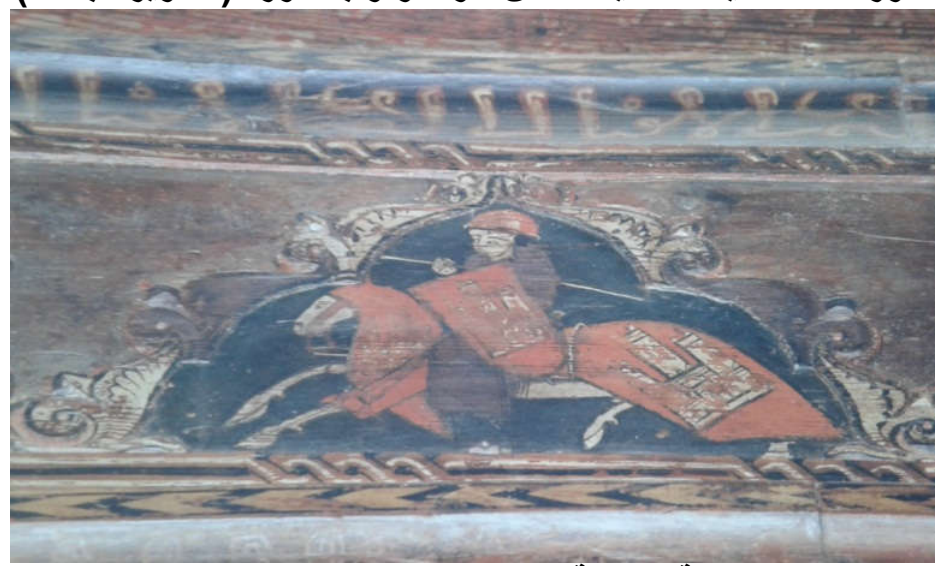

صورة 1 ا : طليطلة، كنيسة سان خوستو و باستور، (تصوير الباحث).

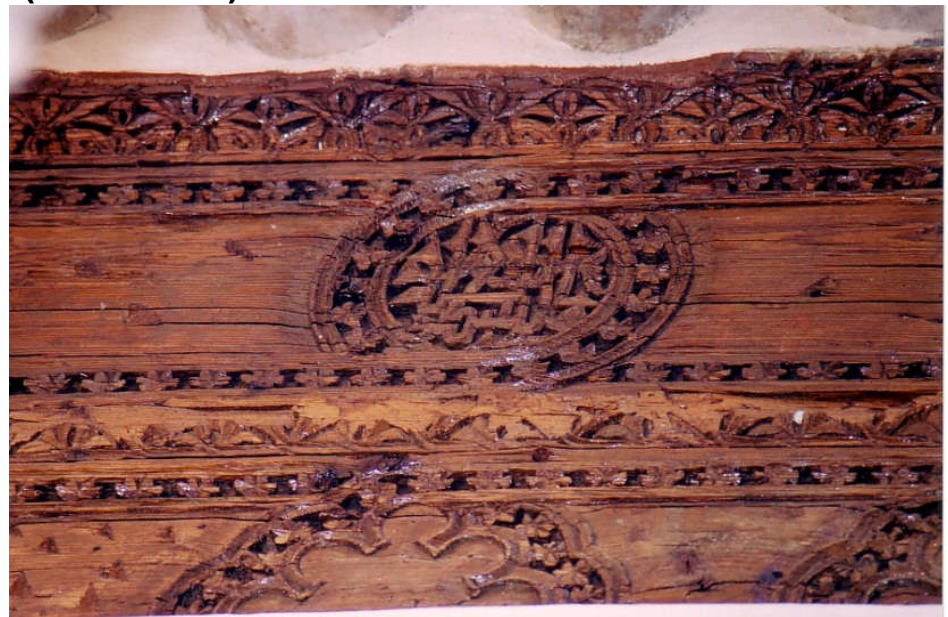

صورة 9 1 : طليطلة، كتابات دير سانتا أورسولا، (تصوير الباحث). 


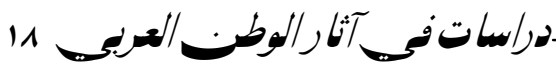

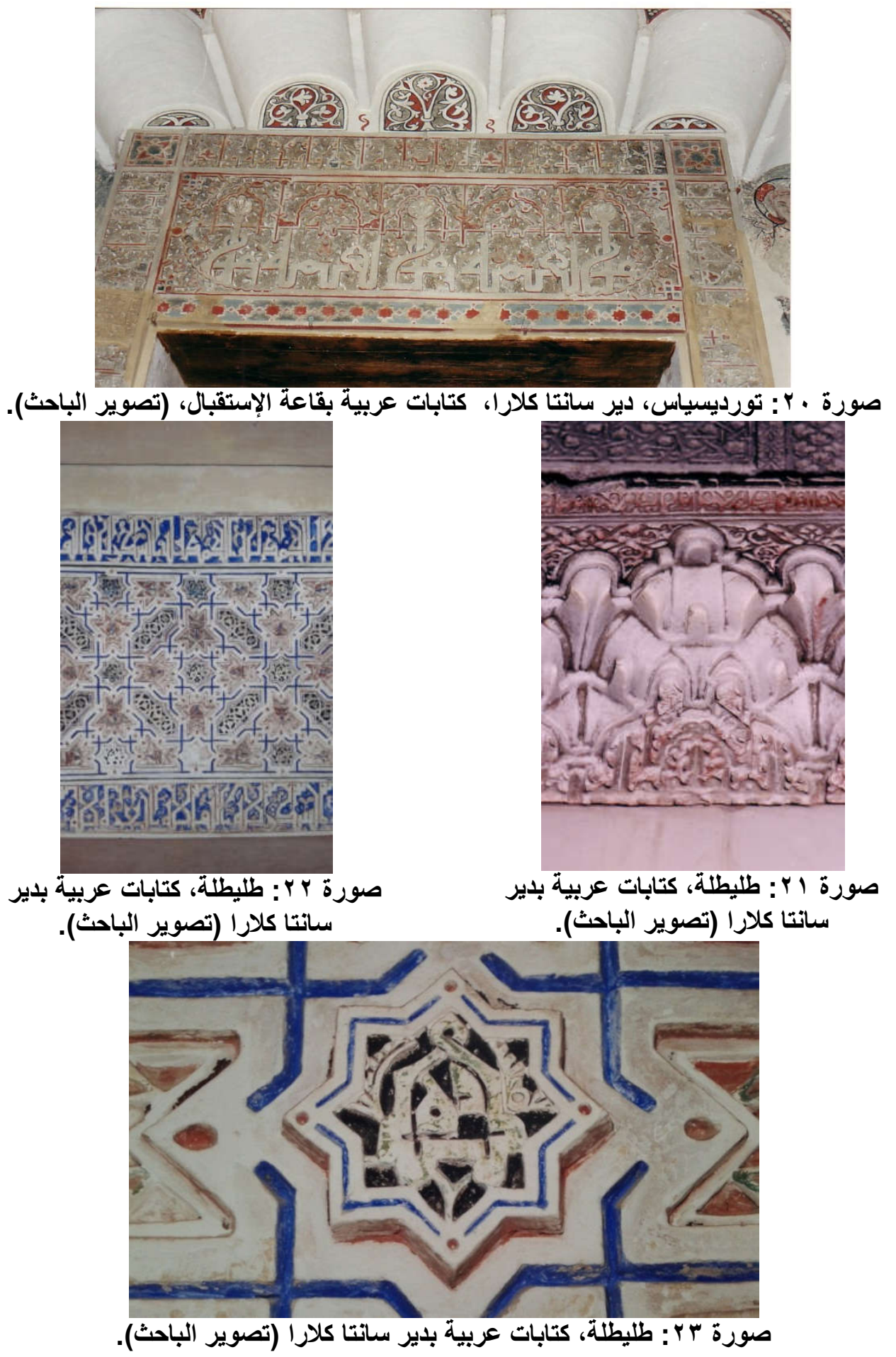




\title{
Arab inscriptions in the churches and monasteries of Toledo Cojoint research
}

\author{
Dr . Ahmed Dokmak \\ Dr . Zeinab Shawki sayed Mohamed
}

\begin{abstract}
:
This research vestifates a new study about the influence of islamic art on Christian Andalusian art through the study of Arabic inscriptions in Modagana andalusian architecture. This research presents important examples of Arabic inscriptions in the churches and monasteries of Toledo, its reading, methods of excution, types of scripts, thus we show an important unknown side of islamic art, in addition, we spot the light on Arabic inscriptions excuted on Christian religious structures that are difficult in their study due to building nature especially that related to monasteries in Toledo as it is difficult to have permission for visiting them even for Christian clerics .
\end{abstract}

\section{Key words:}

Arabic inscriptions in Modagan art, Arabic inscriptions in Toledo, Arabic inscriptions in the churches and monasteries of Toledo, influence of Islamic art on Christian Andalusian art .

\footnotetext{
• Faculty of Archeology, Cairo University, Cairo, Egypt, aznydokmak@hotmail.com
} 